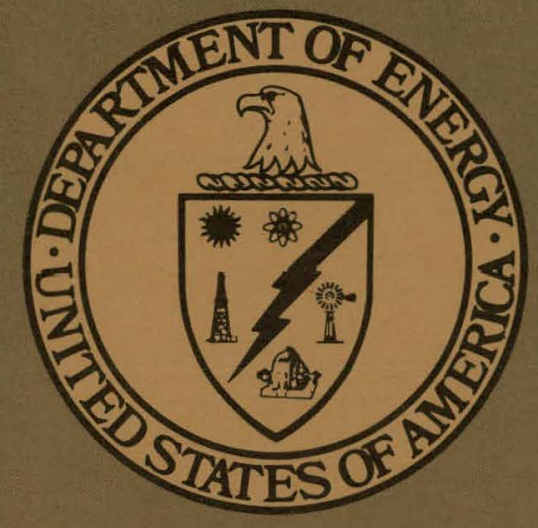

DOE/METC/5202-13

A BIBLIOGRAPHY OF THE PALEONTOLOGY AND PALEOECOLOGY OF THE DEVONIAN-MISSISSIPPIAN BLACK-SHALE SEQUENCE IN NORTH AMERICA

By

Lance S. Barron and Frank R. Ettensohn

June 1980

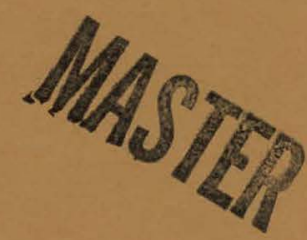

Prepared for

UNITED STATES DEPARTMENT OF ENERGY Morgantown Energy Technology Center Morgantown, West Virginia

Under Contract No. EY-76-05-5202 


\section{DISCLAIMER}

This report was prepared as an account of work sponsored by an agency of the United States Government. Neither the United States Government nor any agency Thereof, nor any of their employees, makes any warranty, express or implied, or assumes any legal liability or responsibility for the accuracy, completeness, or usefulness of any information, apparatus, product, or process disclosed, or represents that its use would not infringe privately owned rights. Reference herein to any specific commercial product, process, or service by trade name, trademark, manufacturer, or otherwise does not necessarily constitute or imply its endorsement, recommendation, or favoring by the United States Government or any agency thereof. The views and opinions of authors expressed herein do not necessarily state or reflect those of the United States Government or any agency thereof. 


\section{DISCLAIMER}

Portions of this document may be illegible in electronic image products. Images are produced from the best available original document. 


\section{DISCLAIMER}

"This book was prepared as an account of work sponsored by an agency of the United States Government. Neither the United States Government nor any agency thereof, nor any of their employees, makes any warranty, express or implied, or assumes any legal liability or responsibility for the accuracy, completeness, or usefulness of any information, apparatus, product, or process disclosed, or represents that its use would not infringe privately owned rights. Reference herein to any specific commercial product, process, or service by trade name, trademark, manufacturer, or otherwise, does not necessarily constitute or imply its endorsement, recommendation, or favoring by the United States Government or any agency thereof. The views and opinions of authors expressed herein do not necessarily state or reflect those of the United States Government or any agency thereof."

This report has been reproduced directly from the best available copy.

Available from the National Technical Information Service, U. S. Department of Commerce, Springfield, Virginia 22161.

Price: Paper Copy $\$ 8.00$

Microfiche $\$ 3.50$ 
DOE/METC/5202-13

Distribution Category UC-92

\title{
A BIBLIOGRAPHY OF THE PALEONTOLOGY AND PALEOECOLOGY OF THE DEVONIAN-MISSISSIPPIAN BLACK-SHALE SEQUENCE IN NORTH AMERICA
}

\author{
By \\ Lance S. Barron and Frank R. Ettensohn \\ of \\ Department of Geology, University of Kentucky \\ Lexington, Kentucky 40506
}

June 1980

Prepared for

UNITED STATES DEPARTMENT OF ENERGY Morgantown Energy Technology Center

Morgantown, West Virginia

Under

Contract No. EY-76-C-05-5202 


\section{CONTENTS}

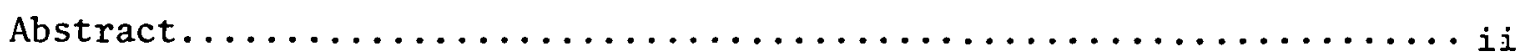

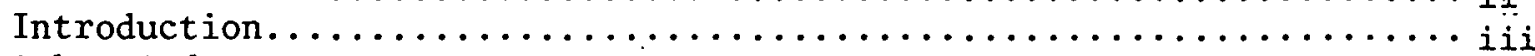

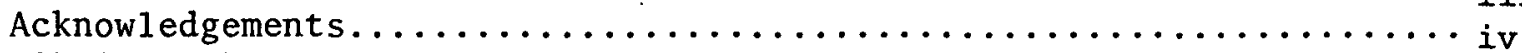

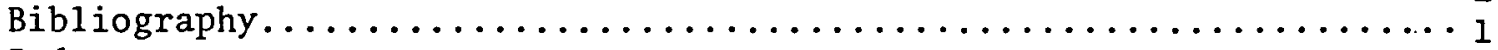

Index.................................. 
A BIBLIOGRAPHY OF THE PALEONTOLOGY AND PALEOECOLOGY

OF THE DEVONIAN-MISSISSIPPIAN BLACK SHALE

SEQUENCE IN NORTH AMERICA

by

Lance S. Barron1/ and Frank R. Ettensohn2/

ABSTRACT

The Devonian-Mississippian black-shale sequence is one of the most prominent and well-known stratigraphic horizons in the Paleozoic of the United States, yet the paleontology and its paleoecologic and paleoenvironmental imp iccations are poorly known. 'lhis is in larger part related to the scarcity of fossils preserved in the shale - in terms of both diversity and abundance. Nonetheless, that biota which is preserved is wellknown and much described, but there is little synthesis of this data. The first step in such a synthesis is the compilation of an inclusive bibliography such as this one. This bibliography contains 1193 entries covering all the major works dealing with Devonian-Mississippian black-shale paleontology and paleoecology in North America. Articles dealing with areas of peripheral interest, such as paleogeography, paleoclimatology, ocean circulation and chemistry, and modern analogues, are also cited. In the index, the various genera, taxonomic groups, and other general topics are crossreferenced to the cited articles. It is hoped that this compilation will aid in the synthesis of paleontologic and paleoecologic data toward a better understanding of these unique rocks and their role as a source of energy.

KEY WORDS: Devonian-Mississippian black-shale sequence, North America, paleontology, paleoecologic and paleoenvironmental implications, synthesis, bibliography, pal eogeography, paleoclimatology, energy.

\section{IN'T'RODUCTION}

The Devonian-Mississippian black-shale sequence is one of the most prominent stratigraphic horizons in the Paleozoic of the United States, and is of great economic importance because of its potential as a gas and oil shale. These shales are remarkable in their homogeneous nature and widespread distribution throughout east-central and mid-western United States with extensions into the Southwest and into west-central Canada. Equally remarkable about these shales, is the apparent scarcity of typical marine fossils. Most studies report an absence of fossils or a restricted fossil fauna composed of the same few invertebrate elements, namely Lingula,

1/ Research Assistant, University of Kentucky

$\overline{2}$ / Assistant Professor of Geology, University of Kentucky 
conodonts, and fish-bone fragments. An unusual floral assemblage consisting of coalified logs (usually Callixylon), Tasmanites, and Foerstia is also typically reported. These are the common floral and faunal elements, and they are reported almost universally from the shales; yet many other floral and faunal elements also occur in these shales, but they usually are rare or local in occurrence. The unusual composition of the black-shale biota and its low diversity are attributed by most workers to widespread anaerobic conditions thought to exist throughout much of the North American epeiric sea at that time. Toward the eastern limits of the shale distribution, however, the fossil fauna gradually increases in diversity and abundance reflecting a change to dysaerobic and aerobic environments as the eastern source areas were approached. Many of the above faunas represent typical open-marine assemblages. Hence, the black-shale sequence is not everywhere typified by a scarcity of fauna and flora.

In order to better characterize the black-shale biota, to study its changes through time and space, and to determine its paleoenvironmental implications, we thought it important initially to compile a bibliography of black-shale paleontology and paleoecology. The following bibliography of 1193 entries is a compilation of all the major articles dealing with the paleoecology of the Devonian-Mississippian black-shale sequence of North America. The compiled references cover the paleontology and paleoecology of black shales ranging from Middle Devonian (Eifelian-Givetian) to Earliest Mississippian (Kinderhookian) in age. Geographically, the references cover areas ranging from Georgia to Alberta and from Arizona to eastern Canada. References dealing with extra-continental Devonian faunas are included for cosmopolitan groups such as the conodonts and cephalopoda. Also included are topics related to paleogeography, paleoclimatology, ocean circulation and chemistry, modern analogues, and blackshale paleoecology. Although some of the articles deal with specific organisms or communities from the black shale, many merely record the occurrences of some rather common, nearly ubiquitous fossils in the black shale. Such references typically mention Tasmanites (Sporangites), Callixylon, Foerstia (Protosalvinia), Styliolina, Lingula, orbiculoid brachiopods, fish scales, and conodonts. A number of the articles are rather old, dating to the 1800's or early 1900's, and hence the nomenclature used for fossils may be outdated, and in some cases, totally inappropriate. Where possible, these names are synonymized with more modern names in the index.

Articles are listed alphabetically and designated with numbers. In the index, various genera, taxonomic groups, and other general topics are crossreferenced to these articles through their numerical designations. All of the articles were examined and verified except those marked with an asterisk $(*)$. 


\section{ACKNOWLEDGEMENTS}

Our.gratitude is extended to Mrs. Vivian Hall, Mrs. Mary Ransbottom Spencer, and the student staff of the University of Kentucky Geology Library for their assistance. We also wish to thank Trudy $\mathrm{H}$. Bellardo of the Reference Department of the Margaret I. King Memorial Library, University of Kentucky. Special thanks are also due Jane T. Wells and Barbara A. Ross respectively for their typing and proofreading of the manuscript.

Funding for this study was provided under contract number EY-76-C-055202 from the Department of Energy, Morgantown Energy Technology Center. 


\section{BIBLIOGRAPḦY}

0001 Aberdeen, E., 1940, Radiolarian fauna of the Cabalios Formation, Marathon Basin, Texas: Journal of Paleontology, v. 14, p. 127-139.

0002

Adams, G. I., and Ulrich, E. 0., 1905, Fayetteville folio, Arkansas-Missouri: U.S. Geological. Survey Geologic Atlas of the United States, Folio no. 119, $6 \mathrm{p}$.

0003 Amsden, T. W., Caplan, W. M., Hilpman, P. L., McGlasson, E. H., Rowland, T. L., and Wise, 0. A., Jr., 1967, Devonian of the southern Midcontinent area, United States: in Oswald, D. H. (ed.), International Symposium on the Devonian System, 1967 Proceedings, Calgary Alberta, Alberta Society of Petroleum Geologists, v. 1, p. 913-932.

0004 Amsden, T. W.; and Klapper, Gilbert, 1972, Misener Sandstone (Middle-Upper Devonian), north-centra1 Oklahoma: American Association of Petroleum Geologists Bulletin, v. 56, p. 23232334.

0005 Anderson, W. I., 1964, Upper Devonian and Lower Mississippian conodont faunas, north-central Iowa: Iowa Academy of Science Proceedings, v. 71, p. 320-334.

0006 _ 1966, Upper Devonian conodonts and the Devonian-Mississippian boundary of north-central Iowa: Journal of Paleontology, v. 40 , p. 395-415.

0007 Andrews, E. B., 1871, Report of progress in the second district: Ohio Geological Survey, Report of Progress 1869, p. 55-142.

0008 Andrews, H. N., and A1t, K. S., 1956, A new fossil plant from the New Albany Shale with some comments on the origin of land vascular plants, Part 1 - Carocalophyton, a new transitional sealand plant, Part 2 - Some comments on the origin of 1 and vascular plants and taxonomic position of Carocalophyton: Annual of the Missouri Botanical Gardens, v. 43, p. 355-378.*

0009 Andrews, H. N., and Phillips, T. L., 1968, Rhacophyton from the Upper Devonian of West Virginia: Journa of the Linnean Society, Botany, v. 51, p. 37-64.*

0010 Andrews, H. N., Read, Charles B., Mamay, Sergius H., 1971, A Devonian lycopod stem with well-preserved cortical tissue: $\mathrm{Pa}-$ laeontologr, v. 14, part 1, p. 1-9.

0011 Anteos, E., 1925, The climatologic significance of annual rings in fossil wood: American Journal of Science, 5 th Series, v. 9, p. 296.

0012 Arber, E. A. Newe11, 1921, Devonian floras: Cambridge, Cambridge University Press.*

0013 Arkle, Thomas, Jr., and others, 1979, Mississippian flora: in The Mississippian and Pennsylvantan (Carboniferous) Systems in the United States - West Virginia and Maryland: U.S. Geological Survey Professional Paper 1110-D, p. D-19.

0014 Arnold, C. A., 1928, Some Devonian plant localities of central and western New York: Science, v. 67, p. 276, 277.

0015 , 1929a, Petrified wood in the New Albany Shale: Science, new series, v. 70, p. 581,582 .

$0016 \ldots$ 1929b, On the radial pitting in Callixylon: American Journal of Rntany, v. 16, p. 391-393. 
0017 Arnold, C. A., 1930, The genus Callixylon from the Upper Devonian of central and western New York: Papers of the Michigan Academy of Science, Arts, and Letters, v. 11, p. 1-50.

0018 , 1931, Callixylon newberryi: contributions to miscellaneous paleontology: University of Michigan Museum Paleontology Contributions, v. 3, p. 207-232.

$0019 \quad$, 1934a, The so-called branched impressions of Callixylon newberryi (Dawson) Elkins and Wieland and the condition of their preservation: Journal of Geology, v. 42, p. 71-76.

0020 , 1934b, Callixylon whiteanum sp. nov. from the Woodford Chert of oklahoma: Botanical Gazette, v. 96, p. 180-185.

0021

0022 , 1935, Some new forms and new occurrences of fossil plants from the Middle and Upper Devonian of New York state: Buffalo Society of Natural Science Bulletin, v. 17, p. 1-12.*

, 1936, Observations on fossil plants from the Devonian of eastern North America: University of Michigan Museum Paleon-

0023 tology Contributions, v. 5, p. 37-55, p. 75-78, p. 271-314. , 1937, Devonian and Mississippian plant-bearing formations in eastern America: Second Congress of Stratigraphy of the Carboniferous, Heerlen 1935, Compte Rendu, v. 1, p. 47-62.

0024 , 1939, Observations on fossil plants from the Devonian of eastern North America: 1. Plant remains from the Catskill Delta deposits of northern Pennsylvania and southern New York: University of Michigan Museum Paleontology Contributions, v. 5, p. 271-313.

0025 , 1952, A specimen of Prototaxites from the Kettle Point black shale of Ontario: Palaeontographica, Abt. B., v. 93, p. 45-56.*

0026 Arthur, M. A., and Schlanger, S. 0., 1979, Cretaceous 'Oceanic Anoxic Events' as causal factors in development of reef-reservoired giant oil fields: American Association of Petroleum Geologists Bulletín, v. 63, p. 870-885.

0027 Ashley, G. H., 1917, Oil resources of black shales of the eastern United States: II.S. Fenlogical Survey Bulletin 641, p. 311-324; (abstr.), Washington Academy of Science Juirnal, v. 7, p. 564 565 .

0028 Avary, K. L., 1979a, Devonian clastics in West Virginia and Maryland, Field Trip Guide: Morgantown, West Virginia, West Virginia Geological and Economic Survey, $100 \mathrm{pp}$.

0029 , 1979b, The Back Creek Siltstone, a newly-named member of the Brallier formation (Upper Devonian) in Virginia and West Virginia: in Avary, K. L. (ed.), Devonian Clastics in West Virginia and Maryland, Field Trip Guide, Morgantown, West Virginin, West Virginia Geological and Economic Survey, p. 89-92.

0030 Baars, D. L., 1972, Devonian System: in Geologic Atlas of the Rocky Mountain Region: Rocky Mountain Association of Geologists, p. 90-99.

0031 Bain, G. W., 1963, Climatic zones throughout the ages: in Munyan, A. C. (ed.), Polar wandering and continental drift, Society of Economic Paleontologists and Mineralogists Special Publication 10 , p. 100-130.

0032 Baker, Roger C., 1942, The age and fossils of the Olentangy Shale of central Ohio: American Journal of Science, v. 240, p. 137143. 
0033 Ba1lard, Norval, 1938, Stratigraphy and structural history of east-central United States: American Association of Petroleum Geologists Bulletin, v. 22, p. 1519-1559.

0034 Barrel1, J., 1913, The Upper Devonian delta of the Appalachian geosyncline: American Journal of Science, 4 th series, v. 36, p. $430-472$.

0035 _ 1914, The Upper Devonian delta of the Appalachian geosyncline - Part II: American Journal of Science, 4th series, v. 37, p. $87-109$.

0036 , 1916, Influence of Silurian-Devonian climates on the rise of air-breathing vertebrates: Geological Society of America Bulletin, v. 27, p. 387-436.

0037 Barrett, N. 0., 1922, Notes on Illinois bituminous shales, including results of their experimental distillation: in Illinois State Geological Survey Bulletin 38, p. 447 .

0038 Barrows, Mary H., Cluff, Robert M., and Harvey, Richard D., 1979a, Petrology and maturation of dispersed organic matter in the New Albany Shale Group of the Illinois Basin: in Third Eastern Gas Shales Symposium, Proceedings, Morgantown, West Virginia, U.S. Department of Energy, Morgantown Energy Technology Center, METC/SP-79/6, p. 85-114.

0039 _ 1979b, Petrology and maturation of dispersed organic matter in the New Albany Shale Group of the I1linois Basin: Illinois State Geological Survey Reprint 1979N, $30 \mathrm{pp}$.

0040 Bass, N. W., 1936, Chattanooga Shale in Osage County, Oklahoma, and adjacent areas: American Association of Petroleum Geologists Bulletin, v. 20, p. 91-102.

0041 Bassler, R. S., 1909, The Nettleroth collection of invertebrate fossils: Smithsonian Miscellaneous Collections 52 (Q15), p. $121-152$.

0042 , 1911, The Waverlian period of Tennessee: U.S. Nationa1 Museum Proceedings, v. 14, p. 209-224.

0043 , 1932, The stratigraphy of the central basin of Tennessee: Department of Education, Division of Geology, Nashville, p. $133-143,234-235$.

0044 Bassler, R. S., and Kellett, Betty, 1934, Bibliographic index of Paleozoic ostracoda: Geological Society of America Speria 1 Paper $1, \mathrm{p}$. 73-87.

0045 Bates, T. F., 1957, Mineralogy, petrography, and radioactivity of representative samples of Chattanooga Shale: Geological Society of America Bulletin, v. 68, p. 1305-1314.

0046 Batrukova, L. S., 1967, Stratigraphic importance of Devonian lingulid brachiopods in the U.S.S.R.: in Oswald, D. H. (ed.), International Symposium on the Devonian System, 1967 Proceedings, Calgary, Alberta, Nlberta Sooioty of Petroleum Geologists, v. 2, p. 525-529.

0047 Reach, G. A., 1961, Late Devonian and Early Mis3issippian biostratigraphy of central Utah: Brigham Young University Research Studies, Geology Series, v. 8, p. 37-54.

0048 Beck, C. B., 1953, A new root species of Callixylon: American Journal of Botany, v. 40, p. 226-233. 
0049 Beck, C. B., 1960a, Studies of New Albany shale plants:

1. Stenokoleos simplex comb. nov.: American Journal of Botany, v. 47, p. 115-124.

$0050,1960 \mathrm{~b}$, The identity of Archaeopteris and Callixylon: Brittonia, v. 12, p. 351-368.

$0051 \quad, 1961$, Callixylon from the New Albany shale (abstr.): American Journal of Botany, v. 48, p. 540.

$0052 \quad, 1962$, Reconstruction of Archaeopteris and further considerations of its phylogenetic position: American Journal of Botany, v. 49, p. 373-382.

0053 , 1964a, Predominance of Archaeopteris in Upper Devonian flora of western Catskil1s and adjacent Pennsylvania: Botanical Gazette, v. 125, p. 126-128.

$0054,1964 \mathrm{~b}$, The woody fern-like trees of the Devonian: Torrey Botany Club Memoir, v. 21, p. 26-37.

$0055 \quad$, 1965, Thie genus Periastron (abstr.): American .Tournal of Botany, v. 52, p. $6 \overline{37}$.

0056 , 1970a, The appearance of gymnospermous structure: Biological Reviews, v. 45, p. 379-400.

0057 , 1970b, Stelar morphology in some progymnosperms (abstr.): American Journal of Botany, v. 57, p. 755.

0058 , 1971, Problems of generic delimitation in paleobotany: in Yochelson, E. L. (ed.), Proceedings of the North American paleontological convention, Lawrence, Kansas, Allen Press, Inc., p. 173-193.

0059 Beck, C. B., and Bailcy, Robert E., 1966, A Lyginorachis-like specimen from the New Albany Shale (abstr.): American Journal of Botany, v. 53, p. 629 .

0060 , 1967, Plants of the New Albany Shale - Part 3, Chapelia campbe11i gen. n.: American Journal of Botany, v. 54, p. 998-1007.

0061 Beecher, C. E., 1884, Ceratiocaridae from the Chemung and Waverly groups of Pennsylvania: Pennsylvania Geological Survey Second Report, p. 1-22.

0062 , 1900, Restoration of Stylonurus lacoanus, a giant arthropod from the Upper Devonian of the United States: American Journal of Science, 4th series, v. 10, p. 145-150; Geological Magazine, 4th series, v. 7, p. 481-485.

0063 ,1902, Revision of the phyllocarida from the Chemung and Waverly groups of Pennsylvania: Quarterly Journal of the Geological Society of London, v. 58, p. 441-449.

0064 Belyoa, Holen P.., Moyer, G. L., Grey, F. F, , and Grayston, L. D., 1961, Upper Devonian: in McCrossan, R. G., and Glaister, R. P. (eds.), Geological History of Western Canada, Alberta Society of Petroleum Geologists, Calgary, Alberta, p. 60-88.

0065 Benson, Richard H., and Collinson, Charles, 1958, 'Mrree ostracode faunas from Lower and Middle Mississippian strata in southern Illinois: Illinois State Geological Survey Circular $255,26 \mathrm{pp}$. 
Bergstrom, Robert E., and Shimp, Neil F., 1977, Geologic and geochemical studies of the New Albany Group in Illinois (Devonian black shale) to evaluate its characteristics as a source of hydrocarbons: Univeristy of Illinois, Illinois State Geological Survey Annual Report, September 30, 1977, U.S. ERDA contract E-(40-1)-5203, p. 57-59.

0067 Berner, R. A., 1970, Pyrite formation in the oceans: in Symposium on Hydrogeochemistry, v. 1, Washington, D. C., Clark Co., p. 402-417.*

0068 Berry, E.W., 1906, Leaf-rafts and fossil leaves: Torrega, v. 6, p. 246-248. , 1927, Devonian floras: American Journal of Science, 5th series, v. 14, p. 109-120. , 1932, A remarkable specimen of Callixylon newberryi (Dawson) Elkins et Wieland, from the Ohio Shale: Ohio Journal of Science, v. 32, p. 385-388. , 1939, Branching of Callixylon: American Journal of Science, v. 237, p. 124-129.

Berry, W. B. N., and Wilde, P., 1978, Progressive ventilation of the oceans - an exploration of the distribution of the lower Paleozoic black shales: American Journal of Science, v. 278, p. 257-275.

Bharadwaj, D. C., Tiwari, R. S., and Venkatachala, B. S., 1973, An Upper Devonian mioflora from New Albany Shale, Kentucky, U.S.A.: Palaeobotanist, v. 19, p. 29-39.*

0074

Boalch, G. T., and Parke, M., 1971, The Prasinophycean genera (Chlorophyta) possibly related to fossil genera, in particular the genus Tasmanites: in Farinacci, A. (ed.), 2d Planktonic Conference, Proceedings, Rome, p. 99-105.*

0075

Bonamo, P. M., and Banks, H. P., 1966, Calamophyton in the MidDevonian of New York State: American Journal of Botany, v. 53, p. 778-791.

0076

Bond, R. H., 1947, Ohio Shale conodonts: Ohio Journal of Science, v. 47, p. 21-37.

0077 Boneham, R. F., 1970, Acritarchs in the New Albany Shale of southern Indiana: Indiana Academy of Science Proceedings, 1969, v. 79, p. 251-262.*

0078 Borden, W. W., 1874, Scott County: Geological Survey of Indiana 6th Annual Report, p. 125.

0079 Bowen, Z. P., Rhoads, D. C., and McAlester, A. L., 1974, Marine benthic communities in the Upper Devonian of New York: Lethaia, v. 7, p. 93-120.

0080 Brack, S. D., and Taylor, T. N., 1972, The ultrastructure and organization of Endosporites: Micropaleontology, v. 18, p. 101-109.

0081 Branson, E. B., 1908a, Notes on Dinichthys terril1i Newberry, with a restoration: Ohio Naturalist, $v \cdot \overline{8, p \cdot 363-369 .}$

0082 , 1908b, Dinichthys intermedius Newberry, from the Huron Shale (of Ohio): Science, new series, v. 28, p. 94.*

0083 , 1909, Notes on some dinichthyids from northern ohio (abstr.): Science, new series, v. 29, p. 197.

0084 1911 , Notes on the Ohio Shale and its fauna: University Bulletin, v. 2, p. 23-32. 
0085 Branson, E. B., 1913, Devonian fishes of Missouri (abstr.): Geological Society of America Bulletin, v. 24, p. 119.

0086 , 1914, The Devonian fishes of Missouri: Missouri University Bulletin, v. 15, p. 59-74.

0087 , 1924, The Devonian of Missouri: Missouri Bureau of Geo1ogy and Mines, 2d series, v. 17, 279 pp.

0088 , 1938a, Stratigraphy and paleontology of the Lower Mississippian of Missouri, Part 1: Missouri University Studies, v. 13, no. 3, p. 1-208.*

$0089 \quad, 1938 \mathrm{~b}$, Stratigraphy and paleontology of the Northview and Hannibal: in Branson, E. B., and others, Stratigraphy and paleontology of the Lower Mississippian of Missouri, Part 2: Missouri University Studies, v. 13, no. 4, p. 3-52.*

0090 , 1944, Devonian of northeastern Missouri: in Illinois Geological Survey Bulletin 68, p. 174-181.

0091 Bransul1, E. B., and Greger, D. K., 1915, Devonian of central Missouri (abstr.): Geological Society of America Bulletin, v. 26, p. 112 .

0092 Branson, E. B., and Meh1, M. G., 1933, Conodonts from the Grassy Creek Shale of Missouri: Missouri University Studies, v. 8, no. 3, p. 171-259.*

0093 , 1934, Conodonts from the Bushberg Sandstone and equivalent formations in Missouri: in Branson, E. B., and others, Stratigraphy and paleontology of the Lower Mississippian of Missouri, Part 2, Missouri University Studies, v. 13, no. 4, p. $128-148 . *$

$0094 \ldots$, 1938, The conodont genus Icriodus and its stratigraphic distribution: Journal of Paleontology, v. 12, p. 156-166.

$0095 \quad 1940 \mathrm{a}$, The recognition and interpretation of mixed conodont fauna: Denison University Scientific Laboratory JourIldl, v. $35,15 \mathrm{pp}$.

$0096 \ldots$ 1940b, The recognition and interpretation of mixed fauna: Denison University Bulletin, v. 40, p. 195-209.

0.97 Breger, Irving A., 1961, Kerogen: in McGraw-Hill Encyclopedia of Science and Technology, New York, McGraw-Hill, v. 7, p. 337 .

0098 Breger, Irving A., and Brown, Andrew, 1962, Kerogen in the Chattanooga Shale: Science, v. 137, p. 221-224.

0099 , 1963, Distribution and types of organic matter in a barred marine basin: New York Academy of Science Transactions, 2d series, v. 25, p. $741-755$.

0100 Bregcr, Irving $\Lambda_{.}$, and Schopf, .T. M., 195., Germanium and uranium in coalified wood from Upper Devonian black shale: Geochemica et Cosmochimica Act.a, v. 7, p, 287-293.

0101 Brett, Carlton E., 1974, Biostratigraphy and paleoecology of the Windom Shale Member (Moscow Formation) in Erie County, N. Y.: in New York State Geological Association Field Trip Guidebook, 46th Annual Meeting, p. G1-G10.

0102 Briggs, C., Jr., 1838, First Annual Report: Ohio Geological Survey, p. 77-80.

0103 Bromley, R. G., 1967, Marine phosphates as depth indicators: Marine Geology, v. 5, p. 503-509. 
0104 Brongersma-Sanders, M., 1948, The importance of upwe1ling water to vertebrate paleontology and oil geology: Afd. Nat. Verh.

K. Ned. Akad. Wet. Afd. Nat., series 2, v. 45, p. 1-112.* , 1971, Origin of major cyclicity of evaporites and bituminous rocks: an actualistic model: Marine Geology, v. 11, p. 123-144.

0106 Brooks, J., Grant, P. R., Muir, Marjorie, Gijze1, P. Van, and Shaw, G., 1971, Sporopollenin: New York, Academic Press, $718 \mathrm{pp}$.

0107 Brown, Andrew, 1956, Uranium in the Chattanooga Shale of eastern Tennessee: U.S. Geological Survey Professional Paper 300, p. 457-467.

0108 Browne, Ruth, 1958, Deposition of the Devonian: in Browne, Ruth, Conkin, J. E., Conkin, Barbara, and MacCary, L. M., Sedimentation and Stratigraphy of Silurian and Devonian rocks in the Louisville area, Kentucky, Field trip itenerary: Geological Society of Kentucky in cooperation with the Kentucky Geological Survey, p. 41-44.

0109 Bryant, W. L., 1921, The Genesee conodonts: Buffalo Society of Natural Science Bulletin, v. 13, no. 2, p. 1-58.*

0110 , 1929, A new Coccosteus from the Portage shales of eastern New York: New York State Museum Bulletin, v. 281, p. 41-46.

0111 Butts, Charles, 1903, Fossil faunas of the 0lean quadrangle: New York State Museum Bulletin 69, p. 990-995.

0112 , 1913, Contributions to the black shale problem (abstr.) : Geological Society of America Bulletin, v. 24, p. 113.

0113 , 1915, Geology and mineral resources of Jefferson Co., Ky.: Kentucky Geological Survey, series 4, v. 3, part 2, 270 pp.

0114 , 1922, The Mississippian series in eastern Kentucky: Kentucky Geological Survey, series 6, v. 7, p. 4-27.

0115 , 1925, Descriptive geology: in Geology and Minera1 Resources of the Equality-Shawneetown area (parts of Gallatin and Saline counties): Illinois State Geological Survey Bulletin 47 , p. 14-16.

0116 , 1926, Geology of Alabama: The Paleozoic rocks, Alabama Geological Survey Special Report 14, p. 158-161.

0117 , 1941, Geology of the Appalachian Valley in Virginia: Virginia Geological Survey Bulletin 52, Part I, 568 pp., Part II, $135 \mathrm{p} 1 \mathrm{~s}$.

0118 Butts, Charles, and Gildersleeve, Benjamin, 1948, Geology and Mineral resources of the Paleozoic area in northwest Georgia: Georgia Department of Mines, Mining, and Geology, The Geological Survey Bulletin, no. 54, p. 39-40.

0119 Butts, Charles, and Weller, S., 1920, Devonian: in Weller, S., The geology of Hardin County and the adjoining part of Pope County: Illinois State Geological Survey Bulletin 4l, p. $87-90$.

0120 Byers, Charles W., 1972, Analysis of paleoenvironments in Devonian black shale by means of biogenic structures (abstr.): Geological Society of America Abstracts with Programs, v. 4, p. 464 . 

paleoenvironments (abstr.): Dissertation Abstracts International, v. 34, p. 2095B.

0122 , 1974, Shale fissility: relation to bioturbation: Sedimentology, v. 21, p. 479-484.

$0123 \ldots$ 1977, Biofacies in euxinic basins, general model: Society of Economic Paleontologists and Mineralogists Special Publication, v. 25, p. 5-17.

0124 , 1979, Biogenic structures of black shale paleoenvironments: Postilla, no. $174,43 \mathrm{pp}$.

0125 Byrer, C. W., and Rhoades, S. J., 1976, Lithologic description of core material from Glen Gery No. 5-745 we11, Rose Township, Carroll County, Ohio: Morgantown, West Virginia, Morgantown Energy Research Center, MERC/TPR-76-6/6, $20 \mathrm{pp}$.

0126 Byrer, C. W., and Trumbo, D. B., 1976, Lithologic description from Nicholas Combs No. 7239 we11, Perry County, Kentucky: Morgantown, West Virginia, Mügantớwn Lnergy Rescarch Con ter, MERC/TPR-76/2, $22 \mathrm{pp}$.

0127 Byrer, C. W., Trumbo, D. B., and Rhoades, S. J., 1976, Lithologic description of cored wells No. 11940 and No. 12041 in the Devonian shale in the Cottageville, West Va. area: Morgantown, West Virginia, Morgantown Energy Research Center, MERC/TPR-76/7, $22 \mathrm{pp}$.

0128 Byrer, C. W., Vickers, M. K., Rhoades, S. J., and Easterday, B. G., 1976, Lithologic description of cored wel1s No. 20402 and No. 20403 in the Devonian shale in Lincoln County, West Virginia: Morgantown, West Virginia, Morgantown Energy Research Center, MERC/TPR-76/9, $58 \mathrm{pp}$.

0129 Caley, J. F., 1943, Paleozoic geology of the London area, Ontario: Canada Department of Mines and Resources, Mines and Geology Branch, Geological Survey Memoir 237 (no. 2470), $171 \mathrm{pp}$.

0130 Calvert, Samue1, 1898, On the geology of Johnson County, Iowa: Amcrican Journal of Science, 4 th series, $y, \dot{h}, n$. 149-151.

0131 Calvert, Warren L., Rẹrnhngen, Ralph J., and Bowman, Rirhard S., 1968, Detailed discussion of outcrops observed at ohio field stops, Friday, May 17, 1968, Geological Aspects of the Maysville-Portsmouth region, southern Ohio and northeastern Kentucky: in Ohio Geological Society - Geological Society of Kentucky Joint Field Conference, p. 21-37.

0132 Calvin, Samue1, 1878, On some dark shale recently discovered below the Devonian limestones at Independence, Iowa; with is notice of its fossils and description of new species: United States Geological and Geographical Survey of the Territories (Hayden) Bulletin 4, p. 725-730; in part, American Journa 1. of Science, 3rd series, v. 15, p. 460-462.

0133 Cameron, Barry, 1968, Commensalism of new serpulid worm from the Hamilton Group (Middle Devonian) of New York: Journal of Paleontology, v. 42, p. 850-852.

0134 _. 1969, New rame for Faleosabella prisca (McCoy), a Devonian worm-boring, and its probable borer: Journal of Paleontology, v. 43, p. 189-192.

0135 Campbe11, Guy, 1937, New Albany Shale (abstr.): Geological Society of America Proceedings, p. 67, 68.* 
0136 Campbe11, Guy, 1946, New Albany Shale: Geological Society of America Bulletin, v. 57, p. 829-903.

0137 Canis, W. G., 1968, Conodonts and biostratigraphy of the Lower Mississippian of Missouri: Journal of Paleontology, v. 42, p. 525-555.

0138 Carluccio, L., 1966, Contributions to the morphology and anatomy of the Devonian progymnosperm Archaeopteris: Ph.D. thesis, Corne11 University, Ithaca, $149 \mathrm{pp}^{*}$

0139 Carman, J. E., 1930, The Hillsboro Sandstone of Ohio: Journal of Geology, v. 38, p. 246-261.

$0140 \quad$, 1947, Geologic section of the Chillicothe test-core: Ohio Journal of Science, v. 47, p. 49-54.

0141 Carman, J. E., and Schillhahn, E. 0., 1929, The Hilisboro Sandstone of Ohio (abstr.): Geological Society of America Bulletin, v. 40, p. $113-114,250-251$.

0142 Carter, J. L., and Carter, R. C., 1970, Bibliography of North American Carboniferous brachiopods: Geological Society of America Memoir 128, $382 \mathrm{pp}$.

0143 Caster, K. E., 1934, The stratigraphy and paleontology of northwestern Pennsylvania: Bulletins of American Paleontology, v. $21,185 \mathrm{pp}$.

0144 Cayeaux, M. L., 1929, Les calcispheres typiques sont des algues siphonees: Academy of Science of Paris Comptes Rendus, v. 188, p. 594-597.

0145 Chadwick, G. H., 1925, Chagrin Formation of ohio: Geological Society of America Bulletin, v. 36, p. 455-464.

0146 Chadwick, W. H., 1935, Faunal differentiation in the Upper Devonian: Geological Society of America Bulletin, v. 46, p. 305-342.

0147 Chaloner, W. G., 1959, Devonian megaspores from Arctic Canada: Palaeontology, v. 1, part 4, p. 321-332.

0148 Chaloner, W. G., and Orbe11, G., 1971, A palaeobiological definition of sporopollenin: in Brooks, J., and others (eds.), Sporopollenin: New York, Academic Press, p. 273-294.

0149 Chaloner, W. G., and Sheerin, Anne, 1979, Devonian macrofloras: in House, M. R., Scrutton, C. T., and Bassett, M. G. (eds.), The Devonian System, Special Papers in Palaeontology, no. 23, p. 145-161.

0150 Chamberlin, T. C., 1900, On the habitat of the early vertebrates: Journal of Geology, v. 8, p. 400-412.

0151 Clark, David L., 1967, Conodonts as indicators of diachronism in Devonian rocks of the Great Basin, United States: in Oswald; D. H. (ed.), International Symposium on the Devonian System, 1967 Proceedings, Calgary, Alberta, Alberta Society of Petroleum Geologists, v. 2, p. 673-677.

0152 Clark, David L., and Fthington, R. L., 1967, Conodonts and zonation of the Upper Devonian in Great Basin: Geological Society of America Memoir 103, 107 pp.

0153 Clarke, J. M., 1882a, New phy11opod crustaceans from the Devonian of western New York: American Journal of Science, 3d series, v. 23 , p. $476-478$.

0154 1882b, Cirriped crustacean from the Devonian: American Journal of Science, 3d series, v. 24, p. 55-56. 
0155 Clarke, J. M., 1883, New discoveries in Devonian crustacea: American Journal of Science, 3d series, v. 25, p. 120-125.

0156 , 1885a, On Devonian spores:- American Journal of Science, 3d series, v. 29, p. 284-289.

0157 , 1885b, On the higher Devonian faunas of Ontario County, New York: U.S. Geological Survey Bulletin 16, $80 \mathrm{pp}$.

0158 , 1887a, Annelid teeth from the lower portion of the Hamilton Group and from the Naples shales of Ontario County, New York: New York State Geological Survey 6th Annual Report, p. 30-33.

$0159 \ldots$, 1887b, A noteworthy specimen of Devonian Lepidodendron: Science, v. 9, p. 516.*

0160 , 1889, A list of the species constituting the known fauna and flora of the Marcellus epoch in the State of New York: New York State Geological Survey, 8th Annual Report, p. 6061; New York State Museum 12nd Nnnual Report, p. 1.06-107.*

$0161 \ldots$, 1891, The fauna with Goniatites intumescens Beyrich in western New York: American Geologist, v. 8, p. 86-105; Neues Jahrbuch für Mineralogie, Geologie, und Palăontologie; Beilage Band, v. I, p. 161-168.

0162 1892, The discovery of Clymenia in the fauna of the intumescens zone (Naples beds) of western New York, and its geological significance: American Journal of Science, 3d series, v. 43 , p. 57-63.

0163 , 1893a, On the structure of the carapace in the Devonian crustacean Rhinocaris: and the relation of the genus Mesothyra and the Phyllocarida: American Naturalist, v. $2 \overline{7}$, p. 793-801.

0164 , 1893b, The protoconch of Orthoceras: American Geologist, v. 12, p. $112-115$.

0165 . 1896, The structure of certain Paleozoic barnacles: American Geologist, v. 17, p. 137-143.

0166 , 1897, Notes on some crustaceans from the Chemung Group of New York: New York State Geological Survey, 15th Annual Report, p. 729-738; New York State Muscum, 49th Annual Report, v. 2, p. 729-738.*

0167 _ 1899, The Naples fauna (fauna with Manticoceras intumescenes) in western New York: New York State Geologist, 16th Annual Report, p. 29-161; New York State Museum, 50th Annual Report, v. 2, p. 29-161.*

0168 , 1900a, A remarkable occurrence of Orthoceras in the Oneonta beds of the Chenango Valley, New York: New York State Museum Bulletin 39, p. 167-171.

0169 _ 1900b, Paropsonema cryptophya, a peculiar echinoderm from the intumescens zone (Portage beds) of western New York: New York State Museum Bulletin 39, p. 172-186.

$0170 \quad$, 1900c; Dictyonine hexactinellid sponges from the Upper Devonic of New York (Nepheliospongia): "New York State Museum Bulletin 39, p. 187-194.

0171 . 1901a, Limestones of central and western New York, interbedded with bituminous shales of the Marcellus Stage; with notes on the nature and origin of their faunas: New York State Museum Bulletin 49, p. 115-138.* 
0172 Clarke, J. M., 1901b, Value of Amnigenia as an indicator of fresh-water deposits during the Devonic of New York, Ireland, and the Rhineland: New York State Museum Bulletin 49 , p. 199-203.*

0173 , 1902a, Notes on Paleozoic crustaceans (Psuedoniscus and Phyllocarida): New York State Museum, 54th Annual Report, v. 1, Appendix 3, p. 83-124.*

$0174 \ldots$ _ 1902b, A new genus of Paleozoic brachiopods, Eunoa; with some considerations there from on the organic bodies known as Discinocaris, Spathiocaris, and Cardiocaris: New York State Museum Bulletin 52, p. 606-615.*

0175 , 1902c, The indigene and alien faunas of the New York Devonic: New York State Museum Bulletin 52, p. 664-672.*

$0176 \ldots$ 1903a, Naples fauna in western New York: New York State Museum, Report 57, v. 3, Memoir 6, p. 199-201.

0177 , 1903b, Origin of the limestone faunas of the Marcellus Shales of New York (abstr.): Geological Society of America Bulletin, v. 13, p. 535; Science, new series, v. 17, p. 219.

0178 Clarke, J.M., and Swartz, C. K., 1913, Systematic paleontology of the Upper Devonian deposits of Maryland: in Middle and Upper Devonian, Maryland Geological. Survey, v. 6, p. 539-699.

$0179 \quad$ 1915, Conceptions regarding the American Devonic: New York Museum Bulletin 177, p. 115-133.

$0180 \ldots$ 1917, Strand and undertow markings of Upper Devonian time as indicators of the prevailing climate: New York State Museum Bulletin 196, p. 197-238.

0181 , 1921, The oldest of the forests: Scientific Monthly, January, p. 83-91.*

0182 Clarke, J. M., and Ruedemann, Rudo1f, 1912, The Eurypterida of New York: New York State Museum Memoir 14, Parts I and II, $439 \mathrm{pp} ., 88 \mathrm{pls}$.

0183 Claypole, E. W., 1883a, Note on a large fish-plate from the upper Chemung (?) beds of northern Pennsylvania: American Philosophical Society Proceedings, v. 20, p. 664-666.*

$0184 \quad 1883 \mathrm{~b}$, On a large crustacean from the Catskill group of Pennsylvania (abstr.): Proceedings of the American Association for the Advancement of Science, v. 32, p. 265; Science, v. 2 , p. 327.*

$0185 \ldots$, 1885, On Ctenacanthus and Gyracanthus from the Chemung of Pennsylvania (abstr.): Proceedings of the American Association for the Advancement of Science, v. 33, p. 489-490.*

0186 , 1887, Preliminary note on some fossil wood from the Carboniferous rocks of Ohio (abstr.): Proceedings of the American Association for the Advancement of Science, 35 th Meeting, 1886, p. 219-220.

0187 , 1888, Fossil fish from the Ohio shale: American Geologist, v. 2, p. 62-64.

0188 , 1892a, Dentition of Titanichthys and its allies (abstr.): American Geologist, v. 10, p. 193 .

$0189 \ldots$, 1892b, The head of Dinichthys: American Geologist, v. 10, p. 199-207.

$0190 \quad$, 1892c, A new gigantic placoderm from Ohio: American Geologist, v. 10, p. 1-4. 
0191 C1aypole, E. W., 1893a, The cladodont sharks of the Cleveland Shale: American Geologist, v. 11, p. 325-331.

0192 , 1893b, The fossil fishes of Ohio: in Economic geology, archaeology, botany, paleontology, Ohio Geological Survey Reports, v. 7, p. 602-626.

$0193 \ldots$ _ $1893 \mathrm{c}$, A new coccostean - Coccosteus cuyahogae: American Geologist, v. 11, p. 167-171.

$0194 \ldots$ 1893d, The three great fossil placoderms of Ohio: American Geologist, v. 12, p. 89-99.

$0195 \ldots$ 1893e, On three new species of Dinichthys: American Geo1ogist, v. 12, p. 275-279.

$0196 \ldots$ 1893f, The Upper Devonian fishes of Ohio: Geological Magazine, v. 10 , p. 443-448.

0197 _ 1894a, Cladodus? magnificus, a new selachian: American Geologist, v.14, p. 137-140.

$0198 \quad, 1894 \mathrm{~b}$, On a new placoderm, Brontichthys clarki, from the Cleveland Shale: American Geologist, v. 14, p. 379-380.

0199 _ 1894c, Structure of the bone of Dinichthys: American Microscopical Society Proceedings, v. 15, p. 1-7.*

U2U0 , 1895a, The grent Dovonian placoderthe nf nhiu: Geological Magazine, (4), v. 2, p. 473-474.

0201 1895b, The cladodonts of the Upper Devonian of Ohio: Peport of the Rritiah Association for the Advancement of Science, p. 695.*

0202 , 1895c, On a new specimen of Cladodus clarki: American

0203

0204

0205

0206 Geologist, v. 15, p. 1-7. , 1895d, Recent contributions to our knowledge of the cladodont sharks: American Geologist, v. 15, p. 363-368. , 1895e, Actinophorus clarki Newberry: American Geologist, v. $16, p . \overline{20-25}$. , 1895f, On the structure of the teeth of the Devonian cladodont sharks: American Microscopical Society, Proceedings ; v. 16, p. 191-195."

Ohio: American Geologist, v. 17, p. 349-360

$0207 \ldots$, 1896a, A new Titanichthys: American Geologist, v. 17, p. 166-169.

$0208 \ldots$ _ 1896b, Dinichthys prentis-clarki: American Geologist, v. 18, p. 199-201.

$0209 \quad \ldots$ _ 1897, A new Dinichthys - Dinichthys kepleri: American Geologi.st, v. 19, p. 322-324.

$0210 \quad$ 1900, The American Devonian placoderms: Geological Society of America Bulletin, v. 11, p. 616.

0211 , 1903, The Devonian era in the Ohio Basin: American Geologist, v. 132, म. $11=41,79-105,240-250,312-3.2 ?$, $335-353$.

0212 Cleland, H. F., 1903, Fauna of the Hamilton formation of the Cayuga Lake section in central New York: U.S. Geological Survey Bulletin 206, $112 \mathrm{pp}$.

0213 , 1911, The fossils and stratigraphy of the middle Devonic of Wisconsin: Wisconsin Geological Survey Bulletin 21, science series 6,222 pp.* 
0214 Cleveland Museum of Natural History, 1923, Fish of the black shale: Cleveland Museum of Natural History Bulletin, v. 8, p. $29-30 . *$

0215 , 1924, Extinct ocean fishes found in rocks near Cleveland: Cleveland Museum of Natıral History Bulletin, v. 16, p. 6163.*

0216 ,1926, Harvesting fossils with an electric shovel: Cleveland Museum of Natural History Bulletin, v. 36, p. 141-142.*

0217 Cloud, Preston, E., 1948, Assemblages of diminuitive brachiopods and their paleoecological significance:.. Journal of Sedimentary Petrology, v. 18, p. 56-60.

0218 Cloud, Preston E., Barnes, V. E., and Hass, W. H., 1957, Devonian-Mississippian transition in central Texas: Geological Society of America Bulletin, v. 68, p. 807-816.

0219 Cobb, J. C., and Kulp, J. L., 1960, U-Pb age of the Chattanooga Shale: Geological Society of America Bulletin, v. 71, p. 223224.

0220 Colbert, Edwin, H., 1961, Placoderms: in Evolution of the Vertebrates, New York, John Wiley and Sons, p. 33-41.

0221 Collins, Horace R., 1979, Biostratigraphy: in The Mississippian and Pennsylvanian (Carboniferous) Systems in the United States - Ohio: U.S. Geological Survey Professional Paper $1110-\mathrm{E}, \mathrm{p} . \mathrm{E}-17$.

0222 Collinson, Charles, 1958, Age of the Springville Shale (Mississippian) of southern Illinois: Illinois State Geological Survey Circular 254, $12 \mathrm{pp}$.

0223 , 1961, The Kinderhookian Series in the Mississippian Valley: in Kansas Geological Society Guidebook, 26th Annual Field Conference, p. 100-109.

0224 , 1967, Devonian of the north-central region, United States: in Oswald, D. H. (ed.), International Symposium on the $\overline{D e v o n i a n}$ System, 1967 Proceedings, Calgary, Alberta, Alberta Society of Petroleum Geologists, v. 1, p. 933-971.

0225 _ 1969, Devonian-Mississippian biostratigraphy of northeastern Missouri and western Illinois: North American Paleontological Association, Field Trip 3, $23 \mathrm{pp}$.

0226 Collinson, Charles, and Atherton, Elwood, 1975, Knobs Megagroup: in Willman, H. B., and others, Handbook of Illinois Stratigraphy: Illinois State Geological Survey Bulletin 95, p. 119123.

0227 Collinson, Charles, Rexroad, C. B., and Scott, A. J., 1959, Abundance and stratigraphic distribution of Devonian and Mississippian conodonts in the upper Mississippi Valley: Journal of Paleontology, v. 33, p. 692-696.

0228 Collinson, Charles, and Schwalb, H. R., 1955, North American Paleozoic Chitinozoa: Illinois Geological Survey Report of Investigations $186,33 \mathrm{pp}$.

0229 Collinson, Charles, Scott, A. J., and Rexroad, C. B., 1962, Six charts showing biostratigraphic zones, and correlations based on conodonts from the Devonian and Mississippian rocks of the upper Mississippi valley: Illinois State Geological Survey Circular $328,32 \mathrm{pp}$. 
0230 Conant, L. C., 1952, Origin of the Chattanooga Shale: U.S. Geological Survey Trace Element Investigation Report 237.

0231 , 1955, Environment of accumulation of the Chattanooga Shale: U.S. Geological Survey Professional Paper 300, p. 463-467.

0232 Conant, L. C., and Stansfield, R. G., 1968, Oil Shale: in Mineral Resources of the Appalachian Region, U.S. Geological Survey Professional Paper 580, p. 133-136.

0233 Conant, L. C., and Swanson, V. E., 1961, Chattanooga Shale and related rocks of central Tennessee and nearby areas: U.S. Geological Survey Professional Paper 357, 91 pp.

0234 Conkin, J. E., 1961, Mississippian smaller foraminifera of Kentucky, southern Indiana, northern Tennessee, and south-central Ohio: Bulletins of American Paleontology, v. 43, p. $129-368$.

0235 Conkin, J. E., and Conkin, B. M., 1964a, Devonian foraminifera: Part I. The Louisville Limestone of Missouri and Illinois: Bulletins of American Paleontology, v. 47, p. 53-105.

$0236 \ldots$, 1964b, Pre-Pennsylvanian arenaceous foraminifera of North America: 22d International Geologica1. Congress, Section 8, Palaeontology and Stratigraphy, p. 319-335.

0237 _. 1967, Arenaceous foraminifera as a key to Upper DevonianLower Mississippian relationships in the type Mississippian area: ' in Teichert, Curt, and Yochelson, Ellis L. (eds.), Essays in Paleontology and Stratigraphy, R. C. Molore Commemorative Volume, University of Kansas Department of Geo1ogy, Special Publication 2, Lawrence, University of Kansas Press, p. 85-101.

0238 , 1973, The Paracontinuity and the determination of the Devonian-Mississippian boundary in the type Lower Mississippian area of North America: University of Louisville Studies in Paleunlulogy and Stratigraphy, no. $1,36 \mathrm{pp}$.

0239 , 1974, The L zone of the Middle Devonian (Hamiltonian) Delaware Formation of central Ohio (abstr.): North Central Section, 8th Annual Meeting, Geological Socicty of Nmerica Abstracts with Programs, v. 6, p: $500-501$.

0240 , 1975a, The Devonian-Mississippian and Kinderhookian-Osagean boundaries in the cast-central United States are paracontinuities: University of Louisville Studies in Paleontology and Stratigraphy, no. 4, $54 \mathrm{pp}$.

0241 , 1975b, Middle Devonian bone beds and the Columbus-Delaware (Onondagan-Hamiltonian) contact in central Ohio: Bulletins of Amorican Paleontology, v. 67, p. 99-122.

0242 , 1977, Paleozoic smaller foraminifera of the North American Atlantic borderlands: in Swain, F. M, (ed.), Stratigraphic micropalentology of the Atlantic Basin and borderlands, Developments in Palaeontology and Stratigraphy, no. 6, New York, Elsevier, p. 61-84.

0243 , 1978, The Devonian section at Paris Landing, Stewart county, Tennessee (abstr.): Geological Society of America Abstracts with Programs, v. 10, P. 165. 
0244 Conkin, J. E., and Conkin, B. M., (eds.), 1979, Devonian-Mississippian boundary in southern Indiana and northwestern Kentucky: Field Trip 7, Ninth International Congress of Carboniferous Stratigraphy and Geology, Louisville, University of Louisville, $141 \mathrm{pp}$.

0245 Conkin, J. E., Conkin, B. M., and Lipchinsky, Z. L., 1973, Middle Devonian (Hamiltonian) stratigraphy and bone beds on the east side of the Cincinnati Arch in Kentucky: Part 1 Clark, Madison, and Casey Counties: University of Louisville Studies in Paleontology and Stratigraphy, no. 2, $42 \mathrm{pp}$.

0246 Cook, T. D., and Ba11y, A. W., 1975, Stratigraphic Atlas of North and Central America: Princeton, Princeton University Press, 272 pp.

0247 Cooper, C. L., 1931, Conodonts from the Arkansas Novaculite, Woodford Formation, Ohio Shale, and Sunbury Shale: Journal of Paleontology, v. 5, p. 143-151.

0248 , 1936, Actinopterygian jaws from the Mississippian black shales of the Mississippian valley: Journal of Paleontology, v. 10, p. 92-94.

0249 , 1939, Conodonts from a Bushberg-Hannibal horizon in Oklahoma: Journal of Paleontology, v. 13, p. 379-422.

$0250 \quad$ 1947, Kinderhook micropaleontology (abstr.): Geological Society of America Bulletin, v. 58, p. 1272-1273.

$0251 \ldots$, 1948, Kinderhook micropaleontology: in Weller, J. M. (ed.), Symposium on problems of Mississippian Stratigraphy and Correlation: Journal of Geology, v. 56, p. 353-366.

0252 Cooper, C. L., and Sloss, L. L., 1943, Conodont fauna and distribution of a Lower Mississippian black shale in Montana and Alberta: Journal of Paleontology, v. 17, p. 168-176.

0253 Cooper, G. A., 1930, Stratigraphy of the Hamilton Group of New York: American Journal of Science, 5 th series, v. 19, p. 116$134,214-236$. $^{*}$

$0254 \ldots$ 1933, Stratigraphy of the Hamilton Group of eastern New York: American Journal of Science, 5 th series, v. 26, p. 537551.

$0255 \ldots$ _ 1934, Stratigraphy of the Hamilton Group of eastern New York, Part II: American Journal of Science, 5th series, v. 27, p. $1-12$.

0256 _ 1941, Remarks on correlation of Devonian formations in Illinois and adjacent states: in Illinois Geological Survey Bu1letin 68, p. 217-223.

0257 _ 1957, Paleoecology of the Middle Devonian of eastern and central United States: in Ladd, H. S. (ed.), Treatise on Marine Ecology and Paleoecology, Geological Society of America Memoir 67, v. 2, p. 249-278.

0258 Cooper, G. A., and Williams, J. S., 1935, Tully Fornation of New York: Geological Society of America Bulletin, v. 46, p. $781 \cdots 868$.

0259 Cooper, G. A., Butts, Charles, Caster, Kenneth E., Chadwick, G. H., Goldring, Winnifred, Kindle, E. M., Kirk, Edwin, Merriam, C. W., Swartz, F. M., Warren, P. S., Warthin, A. S., and Willard, Bradford, 1942, Correlation of the Devonian sedimentary formations of North America: Geological Society of America Bul1 letin, v. 53, p. 1729=1794. 
0260 Cooper, W. F., 1888, Tabulated 1ist of fossils known to occur in the Waverly of Ohio: Denison University Scientific Laboratory Bulletin, v. 4, p. 123-130.

0261 Cope, E. D., 1891, On the cranial structure of Macropetalichthys: U.S. National Museum Proceedings, v. 14, p. 449-456.

0262 Copper, P., 1966, Ecological distribution of Devonian atrypid brachiopods: Palaeogeography, Palaeoclimatology, and Palaeoecology, v. 2, p. 245-266.

$0263 \ldots$ 1973, New Siluro-Devonian atrypoid brachiopods: Journa1 of Paleontology, v. 47, p. 484-500.

0264 , 1977, Paleolatitudes in the Devonian of Brazil and the Frasnian-Famennian mass extinction: Palaeogeography, Palaeoclimatology, and Palaeoecology, v. 21, p. 165-207.

0265 Cornet,. B., Phillips, T. L., and Andrews, H. N., 1976, Morphology of Rhacophyton certangium and its bearing on frond evolution: Palaeontographica, Abt. B, v. 158, 105-129.*

0266 Coryel1, H. N., and Malkive, D. S., 1936, Some Hamilton ostracodes from Arkona, Ontario: American Museum Novitates, no. 91,20 pp.*

0267 Craig, G. Y., 1952, A comparative study of the ecology and paleoecology of Lingula: Transactions of the Edinburgh Geological Society, v. 15, p. 110-120.

0268 Cressler, C. W., 1974, Geology and ground-water resources of Gordon, Whitfield, and Murray Counties, Georgia: Georgia Geological Survey Information Circular, no. 47, $56 \mathrm{pp}$.

0269 Crickmay, C. H., 1952, Discrimination of later Upper Devonian: Journal of Paleontology, v. 26, p. 585.

0270 Crider, A. F., 1906, Geology and mineral resources of Mississippi: U.S. Geological Survey Bulletin 283, p. 7-12.

0271 Cross, A. 'T'., and Hoskins, J. H., 1951a, Paleobotany of the Devonlan-Mississippiarı black shale: Journal of Palcontology, v. 25, p. 713-728.

0272 , 1951b, The Devonian-Mississippian transiton flora of eastrentral. Int.ted States: Third Congress of the Stratigraphy and Geology of the Carboniferous, Compte Rendu, Heerlen, p. $113-122$.

0273 Crouse, C. S., 1925, An economic study of the black Devonian shales of Kentucky: Kentucky Geological Survey, series 6, v. $21, \mathrm{p}, 58-97$.

0274 Culbertson, Glenn, 1912, The occurrence of hand specimens of jointed structure in the New Albany Shale: Indiana $\Lambda$ cademy of 3 cience Procecding 31911 , p. $171 \cdots 172$.

0275 , 1916, The geology and natural resources of Jefferson Co.: Indiana Department of Geology and Natural Resources 40th Annual Report, p. 223-239.

0276 Curry, R. P., 1975, Miospores from the Upper Devonian (Frasnian) Greenland. Gap Group, Allegheny Front, Maryland, West Virginia, and Virginia, U.S.A.: Review of Palaeobotany and Palynology, v. 20, p. 119-131.

0277 Cushing, H. P., 1912, The age of the Cleveland Shale: American Journal of Science, 4th series, v. 33, p. 581-584.

0278 1915, Diastrophic importance of the unconformity at the base of the Berea Grit in Ohio: Geological Society of America Bulletin, v. 26, p. 205-216. 
0279 Cushman, J. A., and Stainbrook, M. A., 1943, Some foraminifera from the Devonian of Iowa: Contributions from the Cushman Laboratory of Foraminiferal Research, v. 19, part 4, p. 73-79.

0280 Dawson, J. W., 1862, On the flora of the Devonian Period in northeastern America: Quarterly Journal of the Geological Society of London, v. 18, p. 296-330.

$0281 \quad$ 1863, On the flora of the Devonian Period in northeastern America: American Journal of Science, 2d series, v. 35, p. 311-319.

$0282 \ldots$, 1871, On spore cases in coal: American Journal of Science, 3d series, v. 1, p. 256-263.

$0283 \ldots$, 1884, On rhizocarps in the Paleozoic period: Proceedings of the American Association for the Advancement of Science, 32d Meeting, p. 260-264.

$0284 \ldots$ 1886, On rhizocarps in the Erian (Devonian) period in America: Chicago Academy of Science Bulletin, v. 1, p. $105-118$ *

$0285 \ldots$ 1888a, On sporocarps discovered by Prof. E. Orton in the Erian shale of Columbus, Ohio: Canadian Record of Science, v. 3, p. $137-140 .^{*}$

0286 , 1888b, The geological history of plants: London, Kegan, Paul, Trench and Co., $290 \mathrm{pp}$.

0287 , 1893, The study of fossil plants: Geological Society of America Bulletin, v. 5, p. 2-5.

0288

Dawson, J. W., and Penhallow, D. P., 1891, Note on specimens of fossil wood from the Erian (Devonian) of New York and Kentucky: Canadian Record of Science, v. 4, p. 242-244.*

Dean, Bashford, 1893, Contributions to the anatomy of Dinichthys: New York Academy of Science Transactions, v. 12, p. 121-125.* , 1894a, Contributions to the morphology of Cladoselache: Journal of Morphology, v. 9, p. 85-115. , 1894b, A new cladodont from the Ohio Waverly, Cladoselache newberryi n. sp.: New York Academy of Science Transactions, v. 13, p. 115-118.* , 1896, On the vertebral column and fins and ventral armoring of Dinichthys: New York Academy of Science Transactions, v. 15, p. 157-163.* , 1897, Note on the ventral armoring of Dinichthys: New York Academy of Science Transactions, v. $\overline{16, p \cdot 57-61 .}$ , 1899, Devonian fishes for the American Museum: Science, new series, v. 10, p. 978 . , 1901a, On two new arthrodires from the Cleveland Shale of Ohio: New York Academy of Science Memoir, v. 2, p. 86-100.* , 1901b, On the characters of Mylostoma Newberry: New York Academy of Science Memoir, v. 2, part 3, p. 101-109.* 1901c, Paleontological notes: New York Academy of Science Memoir, v. 2, p. 85-134.* 1902, The preservation of muscle fibers in sharks of the Cleveland Shale: American Geologist, v. 30, p. 273-279. , 1909a, Studies on fossil fishes (sharks, chimaeroids, and arthrodires): American Museum of Natural History Memoir, v. 9, p. 211-287. 
0300 Dean, Bashford, 1909b, On the arthrodire Trachostius clarki Newberry: American Museum of Natural Hisory Memoir, v. 9, part 5, p. 211-287.

$0301 \ldots$, 1911a, Collecting fossil fishes in Ohio: American Museum Journa1, v. 11, p. 302-303.

$0302 \ldots$ 1911b, Note on the Ohio placoderm Dinichthys terre11i: Science, new series, v. 34, p. 801 .

0303 Degens, E. T., and Ross, D. A. (eds.), 1974, The Black Sea: Geology, Chemistry, and Biology: American Association of Petroleum Geologists Memoir 20,633 pp.

0304 Degens, E. T., and Stoffers, P., 1976, Stratified waters as a key to the past: Nature, v. 263, p. 22-27.

0305 Deleroryas, Theodore, 1964, Palaeobotany and plant classification: 'in Heywood, V. H., and McNeil1, J. (eds.), Phenetic and phylogenetic classification, London, The Systematics Association, v. 6, p. 29-36.

0306 Dennison, J. M., 1960, Stratigraphy of Devonian Onesquethaw Stage in West Virginia, Virginia, and Maryland: Unpub. Ph.D. thesis, University of Wisconsin, Madison, $339 \mathrm{pp}$.

$0307 \ldots$, 1961, Stratigraphy of Onesquethaw Stage of Devonian in West Virginia and bordering states: West Virginia Geological Survey Bulletin, v. 22, 87 pp.

0308 , 1971, Petroleum related to Middle and Upper Devonian de1taic facies in central Appalachians: American Association of Petroleum Geologists Bulletin, v. 55, p. 1179-1193.

$0309 \ldots$, 1976, Tuff-reworking model for uranium concentration in the Chattanooga Shale (abstr.): Geological Society of America Abstracts with Programs, v. 8, p. $160-161$.

0310 Dennison, J. M., and Boucot, A. J., 1974, Little War Gap at Clinch Mountain provides standard reference section for Silurian Clinch Sandstone and most nearly complete Devonian section in eastern Tennessee: Southeastern Geulogy, v. 16, p. 79-101.

0311 Dennison, J. M., and Hasson, K. 0., 1976, Stratigraphic cross section of Hamilton Group (Devonian) and adjacent strata along south border of Pennsylvania: American Association of Petroleum Geologists Bulletin, v. 60, p. 278-287.

0312 Dennison, J. M., Hasson, K. O., Hoskins, Donald M., Jolley, Rirhard M., and Sevon, William D., 1979, Devonian shales in south-central Pennsylvania and Maryland: 44th Armual Field Conference of Pennsylvania Genlogists. Guidebook, Harrisburg, Pennsylvania, Bureau of Topographic and Geologic Survey, $116 \mathrm{pp}$.

0.313 Dennison, J. M., and Head, J. W., 1975, Sea level variations interpreted from the Appalachlan basill Gilurian and Devonian: Americill Journal of Sciunce, v. ?75, p. 1089=1120.

0314 Dennison, J. M., and Morrison, A. K., 1966, Facies relationships of hystrichospheres in Onesquethaw Stage (Devonian) of central Appalachians (abstr.): American Association of Petroleum Geologists Bulletin, v. 50, p. 610 .

0315 Dennison, J. M., and 'l'extoris, D. A., 1970, Dcvonian Tioga Tuff in northeastern United States: Bulletin of Volcanology, $v$. 34 , p. 289-294. 
0316 Dennison, J. M., and Textoris, D. A., 1971, Devonian Tioga Tuff: Virginia Division of Mineral Resources Information Circular, no. 16, p. 64-68.

0317 , 1978, Tioga Bentonite time-marker associated with Devonian shales in Appalachian Basin: in Schott, Garry L., and others (eds.), First Eastern Gas Shales Symposium, Proceedings, Morgantown, West Virginia, U.S. Department of Energy, Morgantown Energy Research Center, MERC/SP-77/5, p. 166-182.

0318 De Posada, Luis C. Sanchez, 1977, Late Paleozoic ostracodes of western Europe and North America: in Swain, F. M. (ed.), Stratigraphic micropaleontology of $\bar{A}$ t lantic Basin and borderlands: Developments in Palaeontology and Stratigraphy, no. 6, New York, Elsevier, p. 61-84.

0319 de Witt, Wallace, Jr., 1951, Strata of the Berea Sandstone and associated rocks in northeastern Ohio and northwestern Pennsylvania: Geological Society of America Bulletin, v. 62, p. $1347-1370$.

0320 , 1970, Age of the Bedford Shale, Berea Sandstone, and Sunbury Shale in the Appalachian and Michigan basins, Pennsy1vania, Ohio, and Michigan: U.S. Geological Survey Bulletin $1294-\mathrm{G}, 11 \mathrm{pp}$.

0321

de Witt, Wallace, Jr., and Colton, G. W., 1959, Revised Correlations of lower Upper Devonian rocks in western and central New York: American Association of Petroleum Geologists Bulletin, v. 43, p. 2810-2828.

0322 Donnel1, J. R., 1976, Environments of deposition of oil shale (abstr.): American Association of Petroleum Geologists Bulletin, v. 60 , p. 666 .

0323 Downie, C., 1967, The geological history of the microplankton: Review of Palaeobotany and Palynology, v. 1, p. 269-281.

0324 , 1973, Observations on the nature of acritarchs: Palaeontology, v. 16, p. 239-259.

$0325 \quad$, 1979, Devonian acritarchs: in House, M. R., Scrutton, C. T., and Bassett, M. G. (eds.), The Devonian System, Special Papers in Palaeontology, no. 23, p. 185-188.

0326 Downie, C., Evitt, W. R., and Sargeant, W. A. S., 1963, Dinoflagellates, hystrichospheres, and classification of the acritarchs: Stanford University Publications, Geological Sciences, v. 7, p. 1-16.

0327 Downie, C., and Sargeant, W. A. S., 1964, Bibliography and index of fossil dinoflagellates and acritarchs: Geological Society of America Memoir 94, $194 \mathrm{pp}$.

0328 Drewry, G. E., Ramsay, A. T. S., and Smith, A. G., 1974, C1imatically controlled sediments, the geomagnetic field, and trade wind belts in Phanerozoic time: Journal of Geology, v. 82, p. 531-553.

0329 Du Bois, E. P., 1943, Evidence on the nature of conodonts: Journal of Paleontology, v. 17, p. 155-159.

0330 Duden, H., 1897, Some notes on the black slate or Genesse Shale of New Albany, Indiana: Indiana Department of Natural Resources Report 21, p. 109-119. 
0331 Duffield, S. L., 1978, Devonian Conodont Biostratigraphy in a Lincoln County, West Virginia, Core: Unpub. Masters thesis, West Virginia University, Morgantown.*

0332 Duffield, S. L., and Warshauer, S. M., 1979, An integrated study of Mid-Appalachian subsurface shales (Upper Devonian): Conodont biostratigraphy and ostracode paleoecology (abstr.): Geological Society of America Abstracts with Programs, v. 11, p. 10-11.

0333 Dunbar, Car1 0., 1917, Devonian and black shale succession of western Tennessee (abstr.): Geological Society of America Bulletin, v. 28, p. 207.

0334 , 1918, Stratigraphy and correlation of the Devonian of western Tennessee: American Journal of Science, 4 th series, v. 46, p. 732-756.

0335 , 1919, Stratigraphy and correlation of the Devonian of western Tennessee: Tennessee State Geological Survey Bulletin 21, $127 \mathrm{pp}$.

0336 Dunkle, D. H., 1942, The infero-gnathal plates of Titanichthys: Cleveland Museum of Natural History Scientific Publications, v. 8, p. 49-59.*

0337 , 1947, A new genus and species of Arthrodirian fish from the Upper Devonian Cleveland Shale: Cleveland Museum of Natural History Publication, v. 8, p. 103-117.*

$0338 \ldots$, 1964, Preliminary description of a paleoniscoid fish from the Upper Devonian of Ohio: Cleveland Museum of Natural History Scientific Publication, new series, v. 3, p. 1-16.*

0339 Dunkle, D. H., and Bungart, Peter A., 1939, A new Arthrodire from the Cleveland Shale Formation: Cleveland Museum of Natural History Publication, v. 8, p. 13-28.

$0340 \quad 1940$, One of the least known of the Cleveland Shale Arthrodires: Cleveland Museum of Natural History Publication, v. 8, p. $29-47 . *$

$0341 \quad$ 1942, A new genus and species of Arthrodire from the Cleveland Shale: Cleveland Muscum of Natural History Publication; v. 8, p. $65-71$. *

0342 , 1943, Conwints on Diploginathus mirabi1is Newberry: Cleve-. land Museum of Natura 1 History Scientific Publication, v. 8, p. 73-84.*

0343 , 1945a, A new Arthrodiran fish from Upper Devonian Ohio Shales: Cleveland Museum of Natural History, Scientific Publication, v. 8, p. 85-95.*

$0344 \quad 1945 \mathrm{~b}$, Preliminary notice of a remarkable Arthrodirian gnathal plate: Cleveland Museum of Natural History Scientific Publication, v. 8, p. 97-102.*

0345 Dunkle, D. H., and Schaeffer, Bobb, 1973, Tegeolepis clarki (Newberry) a palaeuniscilurim lrom the Upper Jevonian Ohio Shale: Palaeontographica, Abt. A, v. 143, p. 151-158.*

0346 Eastman, Charles, R., 1896a, Observations on the dorsal shields in the Dinichthyids (abstr.): American Geologist, v. 18, p. 222 .

$0347 \ldots$ 1896b, Preliminary note on the relations of certain body plates in the dinichthyids: American Journal of Science, 4 th series, v. 2, p. 46-50. 
0348 Eastman, Charles R., 1897a, On the relations of certain plates in the dinichthyids, with descriptions of new species: Harvard College Museum of Comparative Zoology Bulletin, v. 31, p. $19-44$.* , 1897b, On the characters of Macropetalichthys: American Naturalist, v. 31, p. 493-499. , 1897c, On Ctenacanthus spines from the Keokuk limestone of Iowa: American Journal of Science, 4th series, v. 4, p. $10-12$. , 1897d, Tamiobatis vetustus, a new form of fossil skate (Powell Co., Ky.): American Journal of Science, 4th series, v. 4, p. 85-90.

0352 , 1897e, On the occurrence of fossil fishes in the Devonian of Iowa: Iowa Geological Survey Reports, v. 7, p. 108-116.* , 1898, Some new points in dinichthyid osteology: American Naturalist, v. 32, p. 747-768; (abstr.), Proceedings of the American Association for the Advancement of Science, v. 47, p. 371-372. , 1899a, Upper Devonian fish-fauna of Delaware County, New York: New York State Museum, 51st Annual Report, v. 2, p. 317-327. , 1899b, Descriptions of new Diplodus teeth from the Devonian of northeastern Illinois: Journal of Geology, v. 7, p. 489-493. , 1900, Dentition of some Devonian fishes: Journal of Geology, v. 8, p. 32-41. 1903, Devonian fish fauna of Iowa (abstr.): Geological Society of America Bulletin, v. 13, p. 537. , 1904, On Upper Devonian fish remains from Colorado: American Journal of Science, 4th series, v. 18, p. 253-260. , 1906, Dipnoan affinities of arthrodires: American Journal of Science, 4 th series, v. 21, p. 131-143; (abstr.): Science, new series, v. 23, p. 290: Proceedings of the American Association for the Advancement of Science, v. 55, p. 379.

\section{2}

0363

0364

0365 Edwards, D., 1973, Devonian floras: in Hallam, A. (ed.), Atlas , 1907, Devonic fishes of New York formations: New York State Museum Memoir, v. 10, p. 7-225. , 1908, Devonian fishes of Iowa: Iowa Geological Survey Annual Report (1907), v. 18, p. 29-386. , 1913, Brain structure of fossil fishes from the Caney Shales (abstr.): Geological Society of America Bulletin, v. 24, p. $119-120$.

$$
\text { , 1917, Fossil fishes in the collection of the U.S. National }
$$
Museum: U.S Natịnal Museum Proceedings, v. 52, p. 235-304.

Edwards, B. D., 1979, Animal-sediment relationships in dysaerobic bathyal environments, California continental borderland: Unpub. Ph.D. thesis, University of Southern California, Los Angeles, $102 \mathrm{pp}$. of Palaeobiogeography: New York, E1sevier, p. 105-115.

0366 Elkins, M. G., and Wieland, G. R., 1914, Cordaitean wood from the Indian black shale: American Journal of Science, 4 th series, v. 38, p. 68-78. 
0367 Ellison, Samuel P., 1946, Conodonts as Paleozoic guide fossils: Journal of Paleontology, v. 30, p. 93-110.

$0368 \ldots$ _ 1950, Subsurface Woodford black shale, west Texas and southeast New Mexico: Texas University, Bureau of Economic Geology Report of Investigations, v. 7, $20 \mathrm{pp}$.

0369 Ellison, R. L., 1965, Stratigraphy and paleontology of the Mahantango Formation of south-central Pennsylvania: Pennsylvania Geological Survey Bulletin G-48, $298 \mathrm{pp}$.

0370 E11s, R. W., 1909, Bituminous shales of Nova Scotia and New Brunswick: With notes on the geology of the oil-shales: Canada Geological Survey Summary Report for 1908, p. 132-142.

0371 Emery, K. O., 1960, The sea off southern California: New York, John Wiley and Sons, $366 \mathrm{pp}$.

0372 Emery, K. O., and Hulsemann, J., 1962, The relationships of sediments, life and water in a marine basin: Deep-sea Research, v. 8, p. $165-180$.

0373 Engeln, O. D., and Caster, K. E., 1952, Geology: New York, McGraw-Hill Book Co., Inc., $730 \mathrm{pp}$.

0374 Englund, K. J., 1979, Big Stone Gap Member of the Chattanooga Shale: in Mississippian and Pennsylvanian (Carboniferous) Systems in the United Stgtea .. Virginia: U.S. Genlngiral Survey Professional Paper 1110-C, p. C-4.

0375 Epstein, A. G., 1975, Conodont color alteration - A geothermomotor and index of organic metamnrphism (abstr.): Reservoir, v. $2, \mathrm{p}, 1-2$.

0376 Ethington, R. L., 1965, Late Devonian and Early Mississippian conodonts from Arizona and New Mexico: Journal of Paleontology, v. 39, p. 566-586.

0377 Ettensohn, Frank R., 1979a, Radioactive stratigraphy at the Devonian-Mississippian Boundary: in Ettensohn, F. R., and Dever, G. R. (eds.), Carboniferous Geology from the Appalachian basin to the Illinois basin through Ohio and Kentucky, Field Trip 4, Ninth International Congress of Carboniferous Geology and Stratigraphy, Lexington, University of Kentucky, p. $166-170$.

$0378 \ldots$ _ 1979b, Depositional framework of the Luwer Mississippian subaqueous delta sediments in northeastern Kentucky: in Ettensohn, F. R., and Dever, G. R. (eds.), Carboniferous Geology from the Appalachian basin to the Illinois basin through eastern Ohio and Kentucky: Field Trip 4, Ninth International Congress of Carboniferous Geology and Stratigraphy, Lexington. University of Kentucky, p. 133-136.

0379 Ettensohn, Frank R., Fulton, Linda Provo, and Kepferle, Koy L., 1978, Use of the scintillometer and gamma-ray logs for correlation from the subsurface to the surface in black shale: in Schott, Garry L., and ulliers (eds.), First Eustuini Gas Shales Symposium, Proceedings, Morgantown, West Virginia, U.S. Department of Energy, Morgantown Energy Research Center, MERC/SP-7/5, p. 678-690.

0380 1979, Use of scintillometer and gamma-ray logs for correlation and stratigraphy in homogeneous black shales: Geological Society of America Bulletin, Part I, v. 90, p. 421-423; Part II, v. 90, p. 828-849. 
0381 Evans, Harry A., 1889, The relation of the flora to the geological formations in Lincoln, Co., Ky.: Botanical Gazette, v. 14 , p. $310-314$.*

0382 Fagerstrom, J. A., 1967, Stratigraphic and paleogeographic significance of the Holland Quarry Shale (Lower Devonian), northwestern Ohio: Geological Society of America Bulletin, v. 78, p. 1185-1190.

0383 Farrow, George W., 1975, Techniques for the study of fossil and recent traces: in Frey, $R$. W. (ed.), The study of trace fossils, New York, Springer-Verlag, p. 537-552.

0384 Feldman, Rodney M., Osgood, Richard G., Jr., Szmuc, Eugene J., and Meinke, Deborah W., 1978, Chagrinichnites brooksi, a new trace fossil of arthropod origin: Journal of Paleontology, v. 52, p. 287-294.

0385 Fenschel, T. M., and Riedl, R. J., 1970, The sulfide system: a new biotic community underneath the oxidized layer of marine sand bottoms: Marine Biology, v. 7, p. 255-268.

0386 Fisher, Donald W., 1951, Marcasite fauna of Ludlowville Formation of western New York: Journal of Paleontology, v. 25, p. 365371 .

0387 Fix, C. E., 1958, Selected annotated bibliography of the geology and occurrence of uranium-bearing marine black shales in the United States: U.S. Geological Survey Bulletin 1059-F, p. 263-325.

0388 F1essa, Karl W., 1973, Comparative community ecology of the Chagrin and Bedford shales (Devonian-Mississippian, Ohio) (abstr.): Northeastern Section, 8th Annual Meeting, Geological Society of America Abstracts with Programs, v. 5, p. 160.

0389 Florin, R., 1951, Evolution in cordaites and conifers: Acta Horti Bergiani, v. 15, p. 285-288.*

0390 Flower, Rousseau H., 1938, Devonian brevicones of New York and adjacent areas: Palaeontographica Americana, v. 2, p. 163246.

0391 Foerste, A. F., 1901, Silurian and Devonian limestones of Tennessee and Kentucky: Geological Society of America Bulletin, v. 12, p. 395-444.

$0392 \ldots$ 1 1906, The Silurian, Devonian, and Irvine formations of east-central Kentucky: Kentucky Geological Survey, Bulletin, v. $7,369 \mathrm{pp}$.

$0393 \ldots$, 1909, The Bedford fauna at Indian Fields and Irvine, Kentucky: Ohio Naturalist, v. 9, p. 515-523.

0394 Foreman, Helen P., 1959, A new occurrence of Devonian radiolaria in calcareous concretions of the Huron Member of the Ohio Shale: Journal of Paleontology, v. 33, p. 76-80.

0395 , 1963, Upper Devonian radiolaria from the Huron Member of the Ohio Shale: Micropaleontology, v. 9, p. 267-304.

0396 Freeman, T., and Schumacher, D., 1969, Qualitative pre-Sylamore (Devonian-Mississippian) physiography delineated by onlapping conodont zones, northern Arkansas: Geological Society of America Bulletin, v. 80, p. 2327-2334.

0397 Frey, R. W. (ed.), 1975, The Study of Trace Fossils: New York, Springer-Verlag, 562 pp. 
0398 Froelich, Albert J., 1972, Geologic Map of the Wallins Creek quadrangle, Harlan and Bell Counties, Kentucky; U.S. Geological Survey Geologic Quadrangle Map GQ-1016.

0399 , 1973, Geologic Map of the Louellen quadrangle, southeastern Kentucky: U.S. Geological Survey Geologic Quadrangle Map GQ-1060.

0400 Fullerton, D. S., 1961, The geology of the Silurian and Devonian in the subsurface of Larue County, Kentucky: Unpublished Masters thesis, University of Kentucky, Lexington, $34 \mathrm{pp}$.

0401

Fulton, L. J. P., 1978, Stratigraphy and Sedimentology of Radioactive Devonian-Mississippian Shales of the Central Appalachian Basin: Dissertation Abstracts International, v. 38, no. 7 , p. 3093B.

0402

Funkhouser, W. D., and Webb, W. S., 1928, Ancient life in Kentucky: Kentucky Geological Survey, series 6, v. 34, p. 27.

0403

Gab1e, Krisline M., 1973, Conodonts and Biostratigraphy of the Olentangy Shale (Middle-Upper Devonian) Ohio: Unpublished Masters thesis, Ohio State University, Columbus.

0404 Gill, E. D., 1941, The place of the genus Styliolina in the Paleozoic palaeontology and stratigraphy of Victoria: Proceedings of the Royal Society of Victoria, new series 1, v. 53, no. 1, p. 145-164.

0405 Girty, G. H., 1898, Description of a fauna found in the Devonian black shale of eastern Kentucky: American Journal of Science, 4th series, v. 6, p. 384-394.

0406 , 1901, The Waverly Gruup in northeastern Ohio: Science, new series, v. 13, p. 664.*

0407 _ 1904, Upper Paleozoic rocks in Ohio and northwestern Pennsylvania (abstr.): Science, new series, v. 19, p. 24-25.

0408 __ 1905, The relation of some Carboniferous faunas: Washington Acadeny uf Science Pruceedinys, v. 7, p. $1=26$.

0409 _... 1909, The fauna of the Caney Shale of Oklahoma: U.S. Geological Survey Bulletin 377, $106 \mathrm{pp}$.

$0410 \ldots$ 1912, Geologic age of the Bedford Shale of Ohio: New York Academy of Science Annals, v. 22, p. 295-319.

$0411 \ldots$ 1928a, The generic name Orbiculoidea D'Orbigny and its application: Journal of the Washington Acadcmy of Science, v. 18 , p. 128-142.

$0412 \ldots$ 1928b, Characters of the brachiopod genus Lingulidiscina Whitfield: Journal of the Washington Academy of Science, v. 18, p. 241-249.

$0413 \quad$, 1939, Some 1inguluid she11s from the Late Devonian and Early Carboniferous rocks of Pennsylvania and Ohio: U.S. Geological Survey Professional Paper 193-C, p. 17-67.

0411 Glenister, B. F., 1958, Upper Devonian ammnnoids from the Manticocereras zone, Fitzroy Basin, Western Australia: Journal of Paleontology, v. 32, p. 58-96.

0415 Glover, Lynn, 1959, Stratigraphy and uranium content of the Chattanooga Shale in northeastern Alabama, northwestern Georgia, and castem Tennessce: U.S. Geological Survey Bulletin 1087-E, p. 133-168. 
0416 Goldman, M. I., 1929, Black shale formation in and about Chesapeake Bay: American Association of Petroleum Geologists Bulletin, v. 8, p. 195 ,

0417 Goldring, R., 1962, The trace fossils of the Baggy Beds (Upper Devonian) of North Devon, England: Paläontologie Zeitschrift, v. 36, p. 232-251.*

0418 , 1978, Devonian: in McKerrow, W. S, (ed.), The Ecology of Fossils: Cambridge, The MIT. Press, p. 125-145.

0419 Goldring, R., and Langenstrassen, F., 1979, Open shelf and nearshore clastic facies in the Devonian: in House, M. R., Scrutton, C. T., and Bassett, M. G. (eds.), The Devonian System: Special Papers in Palaeontology, no. 23, p. 81-97.

0420 Goldring, W., 1924, The Upper Devonian forest of seed ferns in eastern New York: New York State Museum Bulletin 251, p. 5072 .

$0421 \ldots$ 1927, The oldest known petrified forest: Scientific Month1y, v. 24, p. 514-529.

0422 , 1929, Handbook of Paleontology for Beginners and Amateurs, Part 1: The Fossils, $356 \mathrm{pp}$.

0423 Goldstein, August, Jr., and Hendricks, T. A., 1953, Siliceous sediments of Ouachita facies in 0k1ahoma: Geological Society of America Bulletin, v. 64, p. 421-442.

0424 Gooday, A. J., 1978, The Devonian: in Bate, R., and Robinson, E. (eds.), A stratigraphical index of British Ostracoda: Liverpool, See1 House Press, Geological Journal Special Issue 8, p. $101-120$.

0425 Gooday, A. J., and Becker, G., 1979, Ostracods in Devonian biostratigraphy: in House, M. R., Scrutton, C. T., and Bassett, M. G. (eds.), The Devonian System, Special Papers in Palaeontology, no. 23, p. 193-197.

0426 Grabau, A. W., 1896, The succession of the fossil faunas in the Hamilton Group at Eighteenmile Creek, N. Y. (abstr.): American Geologist, v. 18, p. 220-221; Science, new series, v. 3, p. $212-213$.

0427 1898-1899, The paleontology of the Eighteenmile Creek and the Lake Shore section of Erie County, New York: Buffalo Society of Natural Science Bulletin, v. 6, p. 1-403.

0428 1899, The faunas of the Hamilton Group of Eighteenmile Creek and virinity in western New York: New York State Geologist 16th Annual Report, p. 227-339; New York State Museum 50th Annual Report, v. 2, p. 227-339.*

0429 , 1906, Types of sedimentary overlap: Geological Society of America Bulletin, v. 17, p. 593-613.

0430,1907 , Age and stratigraphic relations of the Chattanooga black shale (abstr.): Science, new series, v. 25, p. 771.*

0431,1909 , Physical and faunal evolution of North America during Ordovicic, Siluric, and early Devonic time; Journal of Geology, v. 17, p. 209-250.

0432 , 1913a, Early Paleozoic delta deposits of North America: Geological Society of America Bulletin, v. 24, p. 399-512.

0433 , 1913b, Relation of Eurypterids to their environment: Geological Society of America Bulletin, v. 24, p. 498-526. 
0434 Grabau, A. W., 1915a, North American continent in Upper Devonic time (abstr.): Geological Society of America Bulletin, v. 26, p. $88-90$.

0435 , 1915b, The Olentangy Shale of central Ohio and its stratigraphic significance (abstr.): Geological Society of America Bulletin, v. 26, p. 112 .

$0436 \ldots$ 1915c, North American continent in Upper Devonic time (abstr.): Science, new series, v. 41, p. 509-510.

0437

0438

0439 , 1915d, The black shale problem; a study in Paleozoic geography (abstr.): New York Academy of Science Annals, v. 24, p. $378-379 . *$

0438 , 1917a, Age and stratigraphic relations of the 0lentangy Shale of central Ohio, with remarks on the Prout Limestone and so-called Olentangy shales of northern Ohio: Journal of Geology, v. 25, p. 337-343.

\section{0} , $1917 \mathrm{~b}$, Stratigraphic relationships of the Tu1ly Limestone and tho Concsec Shalc in eastern North Anerica: Geulugical Society of America Bulletin, v. 28, p. 945-958.
0441 Grabau, A. W., and 0'Conne11, M., 1917, Were the graptolite shales, as a rule, deep or shallow water deposits?: Geolog- ical Society of America Bulletin, v. 28, p. 959-964; (abstr.): p. 205-206.

0442 Graves, R. W., Jr., 1952, Devonian conodonts from the Caballos Novaculite: Journal of Paleontology, v. 26, p. 610-612.

0443 Gray, Henry H., 1979, The Devonian-Mississippian boundary and earliest Mississippian rocks: in The Mississippian and Pennsylvanian (Carboniferous) Systems of the Unitod Statcs .. Indiana: U.S. Geological Survey Professional Paper 1110-K, p. $\mathrm{K}-7$.

0444 Gray, Jane, and Boucot, Arthur J., 1977, Early vascular 1 and plants: proof and conjecture: Lethaia, v. 10, p. 145-174.

$0445 \ldots$ __. 1979, The Devonian Iand plant Protosalvinia: Lethaia, v. 12, p. $57-63$.

0446 Greger, D. K., 1918, Invertebrate fauna of the Grassy Creek Shale of Missouri (abstr.): Geological Society of America Bulletin, v. 29, p. 95 .

0447 Gregory, W. K., 1941, Grandfather fish and his descendants: Nat.ural History, $v, 48, p, 159=165$.

0448 Greiner, H., 1978, Late Devonian facies inter-relationships in bordering areas of the North Atlantic. and their palengengraphic implications: Palaeogeography, Palaeoclimatology, Palaeoecology, v. 25, p. 241-263.

0449 Gresley, W. S., 1894, Cone-in-cone; how it occurs in the Devonian series in Pennsylvania, U.S.A.: Quarterly Journal of the Gcological Society of London, v. 50, p. 731-739.

0450 Grierson, J. D., and Banks, H. P., 1963, Lycopods of the Devonian of New York state: Palaeontographica, Americana, v. 4, p. 220-295. 
0451 Griffith, C., 1977, Stratigraphy and paleoenvironment of the New Albany Shale (Upper Devonian) of North-Central Kentucky: Unpublished Masters thesis, University of Wisconsin, Madison, $214 \mathrm{pp}$.

0452 Gualtieri, J. L., 1967a, Geologic Map of the Crab Orchard quadrangle, Lincoln County, Kentucky: U.S. Geological Survey Geologic Quadrangle Map GQ-571.

0453 __ 1967b, Geologic Map of the Brodhead quadrangle, East-Central Kentucky: U.S. Geological Survey Geologic Quadrangle Map GQ-662.

0454 Gutschick, R. C., 1947, Origin of some bitumen in the DevonianMississippian black shales and the Eocene Green River Shale (abstr.): Geological Society of America Bulletin, v. 58, p. 1185 .

0455 , 1954, Sponge spicules from the Lower Mississippian of Indiana and Kentucky: American Midland Naturalist, v. 52, p. 501-509.

0456 Gutschick, R. C., and Moreman, W. L., 1967, Devonian-Mississippian boundary relations along the cratonic margin of the United States: in Oswald, D: H. (ed.), International Symposium on the Devonian System, 1967, Proceedings, Calgary Alberta, Alberta Society of Petroleum Geologists, v. 2, p. 1009-1023.

0457 Habicht, J. K. A., 1979, Paleoclimate, paleomagnetism, and continental drift: American Association of Petroleum Geologists Studies in Geology no. 9, 31 pp.

0458 Hall, James, 1867, Palaeontology: containing descriptions and figures of the fossil Brachiopoda of the upper Helderberg, Hamilton, Portage, and Chemung Groups, Geological Survey of New York, v. IV, part 1, 428 pp.

0459 _ 1871, On fossil trees from Gilboa, Schoharie Co., N.Y.: Albany Institute Proceedings, v. 1, p. 129-131.*

$0460 \ldots$ _ 1872, On the occurrence of trunks of Psaronius in an erect position, resting on their original bed, in rocks of the Devonian age in the state of New York (abstr.): Geological Magazine, v. 9, p. 463-465.

0461 , 1879, Palaeontology: containing descriptions of Gastropoda, Pteropoda, and Cephalopoda of the upper Helderburg, Hamilton, Portage, and Chemung Groups: Geological Survey of the State of New York, v. V, part II, 492 pp., 113 pls. (text and plates).

0462 , 1884a, Palaeontology: Lamellibranchiata I: containing descriptions and figures of the Monomyaria of the Helderburg, Hamilton, and Chemung Groups, Geological Survey of the State of New York, v. V, part 1, no. 1, $268 \mathrm{pp}$.

0463 1884b, Note on the Eurypteridae of the Devonian and Carboniferous formations of Pennsylvania: Pennsylvania Geological Survey 2d Report, p. 23-39.*

$0464 \ldots$ _ 1885a, Note on the Eurypteridae of the Devonian and Carboniferous of Pennsylvania; with a supplementary note on Stylonurus excelsior: Proceedings of the American Association for the Advancement of Science, v. 33, p. 420-422. 
Hall, James, 1885b, Palaeontology: Lamellibranchiata II: containing descriptions and figures of the Dimyaria of the upper Helderberg, Hamilton, Portage, and Chemung Groups, Geological Survey of the State of New York, v. V, part I, no. $2,561 \mathrm{pp}$.

0466 $1885 \mathrm{c}$, Note on the intimate relations of the Chemung Group and Waverly Sandstone in northwestern Pennsylvania and southwestern New York (abstr.): Proceedings of the American Association for the Advancement of Science, V. 33, p. 416-419.*

0467 Ha11, James, and Clarke, J. M., 1888a, A list of the species constituting the known fauna and flora of the Marcellus epoch in the state of New York: State Geologist of New York Eighth Annual Report, p. 60, 61.

$0468 \quad, 1888 \mathrm{~b}$, Descriptions of the trilobites and other crustacea of the Oriskany, upper Helderberg, Hamilton, Portage, Chemung, and Catskill Groups: New York Geological Survey, Paleontology, v. 7, p. 1-236.

0469 Hall, James, and Whitfield, R. P., 1872, Description of new species of fossils from the vicinity of Louisville, Ky., and the Falls of the Ohio: New York State Museum, 24th Annual Report, p. 181-200.*

U4\% __ 1875, Crinoids of the Genesee Slate and Chemung Group: Ohio Geological Survey Report, v. 2, part 2, Paleontology, p. 158-161.

0471 Hallam, A., 1967, The depth significance of shales with bituminous layers: Marine Geology, v. 5, p. 481-493.

0472 , 1973, Atlas of Palaeobiogeography: New York, Elsevier, $531 \mathrm{pp}$.

0473 Ham, W. E., 1969, Regional geology: in Geology of the Arbuckle Mountains, Oklahoma Geological Survey Guide Book XVII, p. $11-1.4$.

0474 Ham, W. E., and Nevil1e, Curtis M., Jr., 1960, Common minera1s, rocks, and fossils of Oklahoma: Oklahnma Fenlngicnl Survey Guide Book X, p. $27-28$.

0475 Hantzsche1, W., 1975, Trace fossils and problematica: in Teichert, C. (ed.), Treatise on Invertebrate Paleontology Part W, Miscellanea, Supplement 1, Boulder, Geological Society of America, p. W1-W269.

0476 Hard, E. W., 1931, Black shale deposition in central New York: American Association of Yetroleum Geologists Bulletin, v. 15, p. $165-181$.

.0477 Harker, P., and McLaren, D. J., 1958, The Devonian-Mississippian boundary in the Nlhcrtn. Nncky Mnintsina: in Cinodman, A. T., (ed.), Jurassic and Carboniferous of western Canada: A symposium: American Association of Petroleum Geologists, John Andrew Allan Memorial Volume, p. 244-256.

0478 Harnly, H. J., 1898, "Cone-in-cone" (an impure calcite): Kansas Academy of Science Transactions, v. 15, p. 22.*

0479 Harper, A. R., 1948, Ohio in the making; a brief geologic history of Ohio: Columbus, Ohio State University, College of Education, $80 \mathrm{pp}$. 
0480 Harper, John A., and Piotrowski, Robert G., 1979, Stratigraphic correlation of surface and subsurface Middle and Upper Devonian southwestern Pennsylvania: in Dennison, John M., and others, Devonian Shales in South-Centra1 Pennsylvania and Maryland, 44th Annual Field Conference for Pennsylvania Geologists Guidebook, Harrisburg, Pennsylvania, Bureau of Topographic and Geologic Survey, p. 18-37.

0481 Harris, Anita G., 1978, Conocont color alteration, an organomineral metamorphic index, and its application to Appalachian Basin geology: in Schott, Garry L., and others (eds.), First Eastern Gas Shales Symposium Proceedings, Morgantown, West Virginia, U.S. Department of Energy, Morgantown Energy Research Center, MERC/SP-77/5, p. 620-663.

0482 Harris, J. E., 1938, 1. The dorsal spine of Cladoselache; 2. The neurocranium and jaws of Cladoselache: Cleveland Museum of Natural History Scientific Publication, v. 8, no. 1, p. 1-12. , 1951, Diademodus hydei, a new fossil shark from the Cleveland Shale: Zoological Society of London Proceedings, v. 120, part 4, p. 683-697.

0484 Harvey, R. D., White, W. A., Cluff, R. M., Frost, J. K., and DuMonte1le, P. B., 1978, Petrology of New Albany Shale Group (Upper Devonian and Kinderhookian) in the Illinois Basin, a preliminary report: in Schott, Garry L., and others (eds.), First Eastern Gas Shales Symposium Proceedings, Morgantown, West Virginia, U.S. Department of Energy, Morgantown Energy Research Center, MERC/SP-77/5, p. 328-354.

0485 Hass, W. H., 1947a, Conodont zones in Upper Devonian and Lower Mississippian formations of Ohio: Journal of Paleontology, v. 21, p. $131-141$.

0486 __ 1947b, The Chattanooga Shale type area (abstr.): Geological Society of America Bulletin, v. 58, p. 1189.

0487 _ 1950, Age of the lower part of the Stanley Shale: American Association of Petroleum Geologists, Bulletin, v. 34, p. $1578-1584$.

$0488 \quad$, 1951a, Age of some black shales in cores from northeast Mississippi: Mississippi Geological Society Guidebook, 11th Field Trip, p. 32-33.

0489 , 1951b, Age of the Arkansas Novaculite: American Association of Petroleum Geologists Bulletin, v. 35, p. 2526-2541.

0490 , 1956, Age and correlation of the Chattanooga Shale and the Maury Formation: U.S. Geological Survey Professional Paper 286, 47 pp.

0491 _ 1958, Upper Devonian conodonts of New York, Pennsylvania, and interior states: Journal of Paleontology, v. 32, p. $765-769$.

0492 _ 1959, Conodonts from the Chappel Limestone of Texas: U.S. Geological Survey Professional Paper.294-J, p. 365-399.

0493 Hass, W. H., and Huddle, J. W., 1965, Late Devonian and Early Mississippian age of the Woodford Shale in Oklahoma, as determined from conodonts: U.S. Geological Survey Professional Paper 525-D, p. 125-132. 
0494 Hasson, K. 0., 1966, Lithostratigraphy and Paleontology of the Devonian Harrell Shale along the Allegheny Front in West Virginia and Adjacent States: Unpublished Masters thesis, University of Tennessee, Knoxville, $89 \mathrm{pp}$.

0495 Hasson, K. 0., and Dennison, John M., 1968, Relation of Type Millboro Shale in Virginia to Romney Group (Devonian) of West Virginia and Maryland (abstr.): Geological Society of America Special Paper 115, p. 476-477. , 1979, Devonian shale stratigraphy between Perry Bay and the Fulton Lobe south-central Pennsylvania and Maryland: in Dennsion, John M., and others, Devonian Shales in SouthCentral Pennsylvania and Maryland, 44th Annual Field Conference for Pennsylvania Geologists Guidebook, Harrisburg, Pennsylvania, Bureau of Topographic and Geologic Survey, p. 1-17.

0497 Hasson, K. O., and Liebe, R. M., 1968, Conodont correlation of Tulley Limestone outcrops in Pennaylvania and Wost Virginia (abstr.): Geological Society of America Special Paper 121, p. 443.

0498 Hay, Uliver Perry, 1902, Description of a new specles of Cladudus (C. formosus) from the Devonian of Colorado: American Geologist, v. 30, p. 373-374.

0499 Hecke1, P. H., 1972, Recognition of ancient shallow marine environments: in Recognition of Ancient Sedimentary Environments: Society of Economic Paleontologists and Mineralogists Special Publication 16, p. 226-270.

0500 , 1977, Origin of phosphatic black shale facies in Pennsylvanian cyclothems of mid-continent North America: American Association of Petroleum Geologists Bulletin, v. 61, p. 10451068.

0501 Hecke1, P. H., and Witzke, Brian J., 1979, Devonian world palaeogeography determined from distribution of carbonates and related lithic palaeoclimatic indicators: in House, M. R., Scrutton, C. T., and Bassett, M. G. (eds.), The Devonian System, Special Papers in Palaeontology, no. 23, p. 99-123.

0502 Hedgpeth, J.W. (ed.), 1957, Treatise on marine ecology and paleoecology: Geological Society of America Memoir 67, v. 1, $1296 \mathrm{pp}$.

0503 Heintz, A., 1931a, The antero-1ateral plate in Titanichthys: Annals and Magazine of Natural History, v. 8, p. 208-212.

$0504 \quad$, 1931b, A reconstruction of Stenognathus gouldi (Newberry): Annals and Magazine of Natural History, v. 8, p. 242-249.

$0505 \quad$, 1932, The structure of Dinichthys: A contribution to our knowledge of the Arthrodira: Bashford Dean Memorial Volume, Archaic Fishes, v. 4, p. 115-224.

0506 , 1938, Notes on the Arthrodira: Norsk Geologisk Tidsskrift, v. 18, p. 27 .

0507 , 1968, The spinal plate in Homostius and Dunkleosteus: in Orvig, Tor (ed.), Current Prohlems of Lower Vertebrate Phylogeny, Nobel Symposium 4, Stockholm, 1967 Proceedings, New York, Interscience, p. 145-148. 
0508 Henbest, L. B., 1936, Radiolaria in the Arkansas Novaculite, Caballos Novaculite and Bigfork Chert: Journal of Paleontology, v. 10, p. 76-78.

0509 Herrick, C. L., 1888a, Geology of Licking County, 0. Part IV: Denison University Scientific Laboratory Bulletin, v. 4, p. 97-123.

0510 , 1888b, Geology of Licking County, Ohio, Part 4, the Subcarboniferous and Waverly groups: Denison University Scientific Laboratory Bulletin, v. 3, p. 13-110.

0511 _ 1891, The Cuyahoga Shale and the problem of the Ohio Waverly: Geological Society of America Bulletin, v. 2, p. 31-48.

0512 1893, Observations on the so-called Waverly Group of Ohio: in Orton, E., Economic Geology, Archaeology, Botany, Paleontology, Ohio Geological Survey Reports, v. VII, p. 495-515.

0513 Hershey, Oscar H., 1895, The Devonian series in southwestern Missouri: American Geologist, v. 16, p. 294-300.

0514 Herzer, H., 1902, New fossil plants from the Carboniferous and Devonian: Ohio State Academy of Science, 10th Annual Report, p. $40-48 . *$

0515 Hibbard, P. R:, 1927, Conodonts from the Portage Group of western New York: American Journal of Science, 5th series, v. 13, p. 189-208.

0516 Hickman, R. C., and Lynch, V. J., 1967, Chattanooga Shale investigations: U.S. Bureau of Mines Report of Investigations 6932, $55 \mathrm{pp}$.

0517 Hicks, Lewis Ezra, 1878a, Discovery of the Cleveland Shale in Delaware Co., Ohio: American Journal of Science, 3d series, v. 16, p. $70-71$.

$0518 \ldots \ldots$ _ 1878b, The Waverly Group in central Ohio: American Journa1 of Science, 3d series, v. 16, p. 216-224.

0519 Hinde, G. J., 1879a, On conodonts from the Chazy and Cincinnati Group of the Cambro-Silurian, and from the Hamilton and Genesee Shale divisions of the Devonian, in Canada and U.S.: Quarterly Journal of the Geological Society of London, v. 35, p. 357-368.

$0520,1879 \mathrm{~b}$, On annelid jaws from the Cambro-Silurian, Silurian, and Devonian formations in Canada...: Quarterly Journal of the Geological Society of London, v. 35, p. 370-389; (abstr.), Nature, v. 19, p. 523.

0521,1899 , On radiolarians in the Devonian rocks of New South Wales: Quarterly Journal of the Geological Society of London, v. 55, p. 38-50.

0522 Hitchcock, Charles Henry, 1868a, New American fossil fish from the Devonian: Geological Magazine, v. 5, p. 184-185.

0523. - 1868b, New Carboniferous reptiles and fishes from Ohio, Kentucky, and Illinois: Geological Magazine, v. 5, p. 186187.

0524 , 1903, Notice of a species of Acidaspis from a boulder of Marcellus Shale, found in drift, at West Bloomfield, N. J.: American Museum of Natural History Bulletin, v. 19, p. 97-98.* 
0525 Hlavin, W. J., 1966, A preliminary note on some significant fossil finds from the I-71 paleontological salvage operation: Society of Vertebrate Paleontology News Bulletin, v. 76, p. $49-50$.

0526 _ 1972, New associations of fossil sharks from the Cleveland Shale, Upper Devonian (Famennian) (abstr.): Northeastern Section, 7th Annual Meeting, Geological Society of America Abstracts with Programs, v. 4, p. 21.

0527 _. 1976, Biostratigraphy of the Late Devonian black shales on the Cratonal Margin of the Appalachian Geosyncline (abstr.): Dissertation Abstracts International, v. 37, no. 3, p. 1150B.

0528 Hlavin, W. J., and Boerske, J. R., Jr., 1973, Mylostoma variable Newberry, an Upper Devonian durophagous brachythoracid Arthrodire, with notes on related taxa: Breviora, no. 412,12 pp.*

0529 Hoffmeister, W. S., Staplin, F. L., and Malloy, R. E., 1955, Geologic range of Paleozoic plant spores in North America: Micropaleontology, v. 1, p. 9-27.

0530 Holden, F. T., 1942, Lower and Middle Mississippian stratigraphy of Ohio: Journal of Geology, v. 50, p. 34-67.

0531 Holdsworth, B. K., 1977, Paleozuic radiolaria: Stratigraphic distribution in Atlantic borderlands: in Stratigraphic Micropaleontology of Atlantic Basin and borderlands: Deve1opments in Paleontology and Stratigraphy, no. 6, New York, Elsevier, p. 167-184.

0532 Holmes, Grace A., 1928, A bibliography of the conodonts with descriptions of Early Mississippian species: U.S. National Museum Proceedings, v. 72, p. 1-38.

0533 Hoover, Kar1 V., 1960, Devonian-Mississippian sha1e sequence in Ohio: Ohio Department of Natural Resources, Geological Survey Information Circular 27, $154 \mathrm{pp}$.

0534 Hopkins, Thomas Cramer, 1892, The Eureka Shale of northern Arkansas (abstr.): Proceedings of the American Association for the Advancement of Science, v. 40, p. 256-257.*

0535 Hoskins, J. H., 1930, The genus Callixylon in Ohio: Ohio Academy of Science Procccding3, v. 8, part 7, p. 410-411.

0536 Hoskins, J. R., and Blickle, Arthur H., 1940, Concretionary Callixylon from the Ohio Devonian black shale: American Midland Naturalist, v. 23, p. 472-481.

0537 Hoskins, J. H., and Cross, A. T., 1947, Survey of certain Devonian-Mississippian transition flora, part I, Geological considerations; part II, Paleobotanical considerations (abstr.): Geological Society of America Bulletin, v. 58, p. 1194.

$0538 \ldots$ _ 1951, The structure and classification of four plants from the New Albany Shale: American Midland Naturalist, v. 46, p. 684-716.

0539 _ 1952, The petrifaction flora of the Devonian-Mississippian black sha1e: Palaeobotanist, v. 1, p. 215-238.*

0540 House, M. R., 1962, Observations on the ammonoid succession of the North American Devonian: Journal of Paleontology, v. 36, p. 247-284. 
0541 House, M. R., 1965, A study of the Tornoceratidae: the succession of Tornoceras and related genera in the North American Devonian: Philosophical Transactions of the Royal Society of London, Series B., v. 250, no. 763, p. 79-130.*

0542 , 1968, Devonian ammonoid zonation and correlation between North America and Europe: in Oswald, D. H. (ed.), International Symposium on the Devonian System, 1967 Proceedings, Calgary, Alberta, Alberta Society of Petroleum Geologists, v. 2, p. 1061-1068.

0543 - 1973a, An analysis of Devonian goniatite distributions: in Hughes, N. F. (ed.), Organisms and continents through time: Special Papers in Palaeontology, no. 12, p. 305-317.

0544 1973b, Devonian goniatites: in Hallam, A. (ed.), Atlas of Palaeobiogeography: New York, E1sevièr, p. 97-104.

0545

0546 , 1975a, Facies and time in Devonian tropical areas: Proceedings of the Yorkshire Geological Society, v. 40, p. 233288. , 1975b, Faunas and time in Devonian tropical areas: Proceedings of the Yorkshire Geological Society, v. 40, p. 459490 .

0547

$0548 \quad$ _ 1979 , Biostratigraphy of the early Ammonoidea: in , 1978, Devonian ammonoids from the Appalachians and their bearing on international zonation and correlation: Special Papers in Palaeontology, no. 21, $70 \mathrm{pp}$. House, M. R., Scrutton, C. T., and Bassett, M. G. (eds.), The Devonian System, Special Papers in Palaeontology, no. 23, p. 263-280.

0549 House, M. R., "and Pedder, A. E. H., 1963, Devonian goniatites and stratigraphical correlations in western Canada: Palaeontology, v. 6, p. 491-539.

0550 House, M. R., Scrutton, C. T., and Bassett, M. G. (eds.), 1979, The Devonian System: Special Papers in Palaeontology, no. 23, $353 \mathrm{pp}$.

0551 Huddle, J. W., 1933, Marine fossils from the top of the New Albany Shale of Indiana: American Journal of Science, 5 th series, v. 25, p. 303-314.

0552 , 1934, New Albany conodonts: Bulletins of American Paleontology, v. 21, p. $28-29$.

0553 _ 1968, Redescription of Upper Devonian conodont genera and species proposed by Ulrich and Bassler in 1926: U.S. Geological Survey Professional Paper 578, $55 \mathrm{pp}$.

$0554 \ldots$ 1970, Revised descriptions of some Late Devonian Polygnathid conodonts: Journal of Paleontology, v. 44, p. 1029-1040.

0555 Hueber, F. M., 1961, Psilophytes in the Upper Devonian of New York (abstr.): American Journal of Botany, v. 48, p. 541.

0556 Hughes, N. F., 1973, Organisms and continents through time: Special Papers in Palaeontology, no. $12,334 \mathrm{pp}$.

0557 Hunter, C. D., and Munyan, A. C., 1935, Black shales: in Devonian Shales - A Symposium: Appalachian Geological Society, v. 1,7 .pp.

0558 Hussakof, L., 1905a, Notes on the Devonian 'placoderm' Dinichthys intermedius Newb.: American Museum of Natural History Bulletin, v. 21 , p. 409-414,* 
Hussakof, Louis, 1905b, On the structure of two imperfectly known Dinichthyids: American Museum of Natural History Bulletin, v. 21, p. 409-414.*

0560 , 1906, Studies on the Arthrodira: American Museum of Natural History Memoir, v. 9, part 3, p. 105-154.

0561 , 1908a, Catalogue of types and figured specimens of fossil vertebrates in the American Museum of Natural History, part I, Fishes: American Museum of Natural History Bulletin, v. $25, \mathrm{p}, 1-103$.*

0562 , 1908b, Review of Devonic fishes of the New York formations, by C. R. Eastman: Science, new series, v. 28, p. 311-313.* 1909, The systematic relationships of certain American Arthrodires: American Museum of Natural History Bulletin, v. 26, p. 263-272.

0566 , 1911, Notes on some Upper. Devonian Arthrodira from Ohio, U.S.A., in the British Museum (Natural History): Geological Magazine, 5th serle's, v. 8, p. 123=238. , 1912, Notes on the Devonic fishes from Scaumenac Bay, Quebec: New York State Museum Bulletin, v. 158, p. 127-139. , Dental elements in the Arthrodire Titanichthys (abstr.): Geological. Society of America Bulletin, v. 41, p. 196.

Hussakof, Louis, and Bryant, W. L., 1915, The fauna of the conodont bed (basal Genesee) Eighteenmile Creek, N. Y. (abstr.): Geological Society of America Bulletin, v. 26, p. 154. , 1918, Catalog of the fossil fishes in the museum of the Buffalo Society of Natural Sciences: Buffalo Society of Natural Sciences Bulletin, v. 12, 346 pp.*

0569 Hyde, J. E., 1911, The ripples of the Bedford and Berea formations of central and southern Ohio, with notes on the paleogeography of that epoch: Journal of Geology, v, 19, p. 257269 . Natural History, v. 26, p. 497-504.

0571

0572 1928a, Fossil fishing in Cleveland Shale: Cleveland Museum of Natural History Popular Publication, v. 1, 12 pp.*

0573

0575

0576 , 1928b, Fossil fishing in the Cleveland Shale: Our Garden, August and September Issue. , 1953, Mississippian formations of central and southern Ohio: in Marple, M. F. (ed.), Ohio Geological Survey Bulletin $5 \overline{1,} 335 \mathrm{pp}$. , 1965, Fossil dig - Part 2, An historical review of earlier days: Explorer, v. 7, no. 4, p. 28-31.*

Hylander, C. J., 1922, A Mid-Devonian Cailixylon: American

Journal of Science, 5th series, v. 4, p. 315-321.
Inners, J. D., 1975, The Stratigraphy and Paleontology of the Onesquethaw Stage in Pennsylvania and Adjacent States: Unpublished Ph.D. thesis, University of Massachussetts, Amherst, $666 \mathrm{pp}$.

0577 , 1.979, The Onesquethaw Stage in south-central Pennsylvania and nearby areas: in Dennison, John M., and others, Devonian Shales in South-Central Pennsylvania and Maryland, 44th Annual Field Conference of Pennsylvania Geologists, Guidebook, Harrisburg, Pennsylvania, Bureau of Topographic and Geologic Survey, p. 38-55. 
0578 Irving, E., 1977, Drift of the major continental blocks since the Devonian: Nature, London, v. 270, p. 304-309.

0579 Jarvik, E., 1955, The oldest tetrapods and their forerunners: Scientific Monthly, v. 80, p. 141-154.

0580 , 1968, Aspects of vertebrate phylogeny: in Orvig, Tor (ed.), Current Problems of Lower Vertebrate Phylogeny, Nobel Symposium 4, Stockholm, 1967 Proceedings, New York, Interscience, p. 497-527.

0581 Jillson, W. R., 1919, A bibliography of Kentucky petroleum, natural gas, asphalt, and oil shale: Kentucky.. Department of Geology and Forestry, v. 1, no. 1, p. 37-43.

0582 , 1927, Geology of; the oil shales of the eastern United States: Kentucky Geological Survey, series 6, Pamphlet 10, p. 15 .

0583 1950, Geology of Button Knob and vicinity: Frankfort, Roberts Printing Co., p. 22.

0584 , 1951, Geology of Cumberland County, Kentucky: Frankfort, Roberts Printing Co., p. 61.

0585 , 1958, Geology of Barren County, Kentucky: Frankfort, Perry Publishing Co., p. 63.

0586

0587 , 1963, Geology of the area about Stanton, Kentucky: Frankfort, Roberts Printing Co., p. 18 . , 1964, Geology of the area about Virden, Powell County, Kentucky: Frankfort, Roberts Printing Co., p. 17, 19.

0588

0589

0590

0591

0592 , 1965, The geology of Casey County, Kentucky: Frankfort, Roberts Printing Co., $108 \mathrm{pp}$. , 1969a, The geology of Clark County, Kentucky: Frankfort, Roberts Printing Co., p. 47. , 1969b, The geologic history of Kentucky: Frankfort, Roberts Printing Co., p. 60-63.

Johnson, J. G., 1970, Taghanic onlap and the end of North America Devonian provinciality: Geological Society of America Bulletin, v. 81, p. 2077-2105.

0593 482 .

0593

0594 , 1979, Devonian brachiopod biostratigraphy: in House, M. R., Scrutton, C. T., and Bassett, M. G. (eds.), The Devonian System: Special Papers in Palaeontology, no. 23, p. 291-306.

Johnson, J. G., and Boucot, A. J., 1973, Devonian brachiopods: in Hallam, A. (ed.), Atlas of Paleobiogeography, Amsterdam, Elsevier, p. 89-96.

0595

Johnson, J. H., and Konishi, K., 1958, Studies of Devonian algae: Colorado School of Mines, Quarterly, v. 53, $114 \mathrm{pp.}$

0596 Johnson,. T., 1911, Is Archaeopteris a pteridosperm?: Scientific Proceedings of the Royal Dublin Society, v. 13, p. 114-136.*

0597 Jones, Michael, L., and Dennison, John M., 1970, Oriented fossils as paleocurrent indicators in Paleozoic lutites of southern $\Lambda$ ppalachians: Journal of Sedimentary. Petrology, v. 40, p. 642-649.

0598 Jones, Thomas Rupert, 1890, On some Devonian and Silurian Ostracoda from North America, France, and the Bosphorus: Quarterly Journal of the Geological Society of London: v. 46, p. 534-556. 
0599 Kelley, James C., 1968, Geology of the Chattanooga Shale of the Elkmont quadrangle, Alabama (abstr.): Alabama Academy of Science Journa1, v. 39, p. $208-209$.

0600 Kepferle, Roy C., 1966, Geologic Map of the Howardstown quadrangle, Central Kentucky: U.S. Geological Survey Geologic Quadrangle Map GQ-505.

0601 , 1968, Geologic Map of the Shepherdsville quadrangle, Bullitt County, Kentucky: U.S. Geological Survey Geologic Map GQ-740.

0602 _ 1972, Geologic Map of the Brooks quadrangle, Bullitt and Jefferson Counties, Kentucky: U.S. Geological Survey Geologic Quadrangle Map GQ-961.

$0603 \ldots$, 1973, Geologic Map of the Raywick quadrangle, Kentucky: U.S. Geological Survey Geologic Quadrangle Map GQ-1048.

$0604 \ldots$ _ 1974, Geologic Map of the Louisville East quadrangle, Jefferson County, Kentucky: U.S. Geological Survey Geologic Quadrangle Map GQ-1203.

0605 Kepferle, Roy C., Lundegard, Paul, Maynard, J. B., Potter, Paul Edwin, Pryor, W. A., Samuels, Neil, and Schauf, Frederick J., 1978, Paleocurrent systems in shaly basins: preliminary results for Appalachian Basin (Upper Devonian): in Schot.t, Gary L., and others (eds.), First Eastern Gas Sha $\overline{l e s}$ Symposium, Proceedings, Morgantown, West Virginia, U.S. Department of Energy, Morgantown Energy Research Center, MERC/ SP-77/5, p. 434-441.

0606 Kesling, R. V., and Ploch, R. A., 1960, New Upper Devonian cypridinacean ostracod from southern Indiana: University of Michigan Museum Paleontology Contributions, v. 15, p. 281292.

$060 \%$ Kesling, R. V., Segal1, R. T., and Sorensen, II. D., 1974, Ovcr.lying Upper Devonian shales: in Devonian Strata of Emmet and Charlevoix Counties, Michigan: Michigan University Museum Papers on Palenntology, no. 7. p. 116-120.

0608 Keyes, Charles Rollin, 1897, Relations of the Devonian and Carboniferous in the upper Mississippi Valley: Academy of Science of St. Louis Transactions, v. 7, p. 357-369.*

0609 _ 1902, Devonian interval in Missouri: Geological Society of America Bulletin, v. 13, p. 267-292.

0610 _ 1913a, Marked unconformity between Carboniferous and Devonian strata in upper Mississippi Valley: American Juarnal of Science, 4 th series, v. 36, p. 160-164.

$0611 \ldots$, 1913b, Late Devonic sequence of Iowa region (synopsis): Iowa Academy of Science Proceedings: v. 20, p. 205-206.*

0612 _ 1938, Age of the Chattanooga black shales: PanAmerican Geologist, v. 70, p. 364-366.

0613 Kidston, R. and Lang, W. H., 1924, On the presence of tetrads of resistant spores in the tissue of Sporocarpon furcatum Dawson from the Upper Devonian of America: Royal Society of Edinburgh Transactions, v. 53, p. 597-602.*

0614 Kindle, Edward M., 1898, A catalog of the fossils of Indiana, accompanied by a bibliography of the literature relating to them: Indiana Department of Geology and Natural Resources 22 Annual Report, p. 407-514. 
0615 Kindle, Edward M., 1899, The Devonian and Lower Carboniferous faunas of southern Indiana and central Kentucky: Bulletins of American Paleontology, v. 12, p. 1-112.

0616 , 1900, Devonian fossils and stratigraphy of Indiana: Indiana Department of Geology and Natural Resources 25th Annual Report, p. 529-759.

0617 , 1906, Faunas of the Devonian section near Altoon, Pa.: Journal of Geology, v. 14, p. 631-635.

0618

0619 , 1911, The recurrence of Tropidoleptus carinatus in the Chemung fauna of Virginia: Journal of Geology, v. 19, p. 346-357.

0619

0620 , 1912a, The unconformity at the base of the Chattanooga Shale in Kentucky: American Journal of Science, 4 th series, v. 33, p. 120-136.

0620

0621

0622 , 1912b, The stratigraphic relations of the Devonian shale of northern Ohio: American Journal of Science, 4th series, v. 34, p. 187-213.

\section{1} , 1913, Systematic paleontology of the Middle Devonian deposits of Maryland; Vermes, Ostracoda: Maryland Geological Survey, Middle and Upper Devonian, v. 6, p. 122, 335-338. , 1914, Notes on the Oriskany Sandstone and the Ohio Shale of the Ontario Peninsula: Canada Geological Survey Summary Report 1912, p. 286-290.*

Kirchgasser, W. T., 1974, Notes on the ammonoid and conodont zonations of the Upper Devonian of southwestern New York: in Peterson, Donald M. (ed.), Geology of Western New York State, New York State Geological Association Field Trip Guidebook, 46th Annual Meeting, p. B9-B13. ammonoids from the Upper Devonian of western New York: Journal of Paleontology, v. 49, p. 58-90.
0625 Klapper, G., 1966, Upper Devonian and Lower Mississippian conodont zones in Montana, Wyoming, and South Dakota: University of Kansas Paleontology Contributions, Paper 3, p. $1-43$. , 1975, Revision of Probeloceras Clarke, 1898 and related

0626 Klapper, G., and Furnish, W. M., 1962a, Conodont zonation in the Upper Devonian of eastern Iowa: Iowa Academy of Science Proceedings, v. 69, p. 400-411.

0627 _ 1962b, Devonian-Mississippian Englewood Formation in Black Hills, South Dakota: American Association of Petroleum Geologists Bulletin, v. 46, p. 2071-2078.

0628 Klapper, G., and Phillip, G. M., 1971, Devonian conodont apparatuses and their vicarious skeletal elements: Lethaia, v. 4, p. 429-452.

0629 Klapper, G., Phillip, G. M., and Jackson, J. H., 1970, Revision of the Polygnathus varcus group (Conodonta, Middle Devonian): Neues Jahrbuche für Geologie und Palontologie Monatshefte, no. 11, p. $650-667$.

0630 Klapper, Gilbert, and Ziegler, Willi, 1979, Devonian conodont biostratigraphy: in House, M. R., Scrutton, C. T., and Bassett, M. G. (eds.), The Devonian System, Special Papers in Palaeontology, no. 23, p. 199-224. 
0631 Klein, G. deV., 1967, Comparison of recent and ancient tidal flat and estuarine sediments: American Association for the Advancement of Science Publication 83, p. 207-218.*

0632 Klepser, H. J., 1936, Overlap relations of the Chattanooga Shale (abstr.): Geological Society of America Proceedings, p. $370 . *$

0633 , 1973, The Lower Mississippian rocks of the eastern Highland Rim: Ph.D. thesis, Abstracts of Doctor's Dissertations, no. 24, Ohio State University Press.

0634 Knapp, Thomas S., and Twinem, Joseph C., 1933, Geologic structure of a small area west of Mill Springs, Kentucky: Papers of the Michigan Academy of Science, Arts, and Letters, v. 18, p. 413-420.

0635 Knechte1, M. M., and Hass, W. H., 1938, Kinderhook conodonts from the Little Rocky Mountains, northern Montana: Journal of Paleontology, v. 12, p. $518-519$.

0636 Knowlton, F. H., 1889, A revision of the genus Araucarioxylon of Kraus, with compiled descriptions and partial synonomy of the species: U.S. National Museum Proceedings, v. 12, p. 601-634.

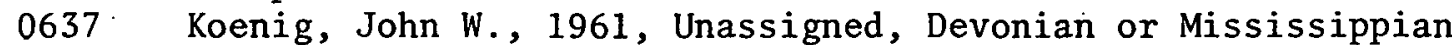
formations: in Koenig, John W., The stratigraphic succession in Missouri, Missouri Division of Geological Survey and Water Resources, 2d series, v. 40, p. 41-49.

0638 Kohout, D. L., and Malcuit, R. J., 1969, Environmental analysis of the Bedford Formation and associated strata in the vicinity of Cleveland, Ohio: Compass, v. 46; p. 192-206.

0639 Konishi, K., 1958, Some Devonian calcareous algae from Alberta, Canada: in Johnson, J. H., and Konishi, K., Studies in Devonian $\overline{\mathrm{Al}} \mathrm{gae}$, part 2, Colorado School of Mines Quarterly, v. 53, p. 65-109.

0640 Krasilov, V. A., 1975, Paleoecology of terrestrial plants: New York, Johu Wiley and Sons, $283 \mathrm{pp}$.

0641 Krebs, Wolfgang, 1979, Devonian basinal facies: in House, M. R., Scrutzon, C. T., and Bassett, M. G. (eds.), The Devonian System, Special Papers in Palaeontology, no. 23, p. 125-139.

0642 Kume, Jack, 1963, The Bakken and Englewood formations of North Dakota and northwestern South Dakota: North Dakota Geological Survey Bulletin $39,87 \mathrm{pp}$.

0643 Kumme1, Bernhard, 1948, Environmental significance of dwarfed cephalopods: Journal of Sedimentary Petrology, v. 18, p. 61-64.

0644 Ladd, H. S. (ed.), 1957, Treatise on Marine Ecology and Paleoecology: Geological Society of America Mcmoir 67, v. 2, $1077 \mathrm{pp}$.

0645 Lalicker, C. G., 1948, Dwarfed protozoan faunas: Journal of Sedimentary Petrology, v. 18, p. 51-55.

0646 Lamar, J. E., Armon, W. J., and Simon, J. A., 1956, Illinois oil shales: Illinois State Geological Survey Circular 208, 21 pp.*

0647 Lamborn, R. E., 1927, The Olentangy Shale in southern Ohio: Journal of Geology, v. 35, p. 708-722. 
0648 Lamborn, R. E., 1929, Notes on the character and occurrence of of. the Olentangy Shale in southern Ohio: Ohio Journal of Science, v. 29, p. 27-28.

0649 Lamey, S. C., and Childers, E. E., 1977, Organic composition of Devonian shale from Perry County, Kentucky: Morgantown, West Virginia, Morgantown Energy Research Center, MERC/TPR$77 / 3,26 \mathrm{pp}$.

0650 Lang, W. H., 1945, The Hooker Lecture: Pachytheca and some anomalous early plants (Prototaxites, Nematothallus, Parka, Foerstia, Orvillea n.g.): Journal of the Linneaen Society, Botany, v. 52, p. 535-552.*

0651 La Rocque, Aurele, and Marple, M. F., 1956, Ohio fossils: Ohio Geological Survey Bulletin 54, p. 19-21, 74-95.

0652 Leatherock, Constance, and Bass, N. W., 1936, Chattanooga Shale in Osage County, Oklahoma and adjacent areas: American Association of Petroleum Geologists Bulletin, v. 20, p. 91101.

0653 Le Conte, Joseph, 1910, Devonian System and the age of fishes: in Elements of Geology: New York, D. Appleton and Co., p. 342-358.

0654 Leidy, Joseph, 1856, Descriptions of some remains of fishes from the Carboniferous and Devonian formations of the United States: Academy of Natural Sciences of Philadelphia Journal: 2d series, v. 3, p. 159-165.*

0655 Lennox, T. H., 1886, The fossil sharks of the Devonian: Canadian Institute Proceedings, 3d series, v. 3, p. 120-121.*

0656 Lesquereaux, L., 1876, Review of the fossil flora of North America: U.S. Geological Survey Territorial Bulletin. (F. V. Hayden in charge), v. 1 , no. 5 , series 2, p. 233-248.

0657 Lewis, R. Q., Sr., 1967a, Geologic Map of the Frogue quadrangle, Kentucky-Tennessee:. U.S. Geological Survey Geologic Quadrangle Map GQ-675.

$0658 \ldots$ _ 1967b, Geologic Map of the Dubre quadrangle, southern Kentucky: U.S. Geological Survey Geologic Quadrangle Map GQ-676.

0659 . Lewis, T. L., 1976, Late Devonian and Early Mississippian paleoenvironments, northern Ohio (abstr.): Geologica1 Society of America Abstracts with Programs, v. 8, p. 220.

0660 Lewis, T. L., and Schwietering, J. F., 1971, Distribution of the Cleveland black shale in Ohio: Geological Society of America Bulletin, v. 82, p. 3477-3482.

0661 Lindstrom, M., 1974, The conodont apparatus as a food-gathering mechanism: Palaeontology, v. 17, p. 729-744.

0662 l.ineback, J. A., 1964, Stratigraphy of the New Albany Shale in southeastern Indiana (abstr.): Geological Society of America Special Paper 76, p. 102, 105.

0663 , 1965, Stratigraphy and Depositional Environment of the New Albany Shale (Upper Devonian and Lower Mississippian) in Indiana (abstr.): Dissertation Abstracts International, v. 25 , no. 11 , p. $6538 \mathrm{~B}$.

0664 , 1968, Subdivisions and depositional environments of the New Albany Shale (Devonian-Mississippian) in Indiana: American Association of Petroleum Geologists Bulletin, v. 52, p. 1291-1303. 
0665 Lineback, J. A., 1970, Stratigraphy of the New Albany Shale in Indiana: Indiana Geological Survey Bulletin 44, 73 pp.

0666 Linney, W. M., 1882a, Geology of Lincoln County: Geological Survey of Kentucky, series 2, v. 3, p. 20-22.

0667 , 1882b, Report on the geology of Garrard County: Kentucky Geological Survey, series 2, v. 3, $30 \mathrm{pp}$.

$0668 \ldots$ 1884a, Report on the geology of Spencer and Ne1son Counties: Geological Survey of Kentucky, series 2, v. 5, part 1, p. 46-50.

0669 _ 1884b, Report on the Geology of Clark County: Geological Survey of Kentucky, series 2, v. 5, part 2, p. 33-37.

0670 Linsley, R. M., 1979, Gastropods of the Devonian: in House, M. R., Scrutton, C. T., and Bassett, M. G. (eds.), The Devonian System: Special Papers in Palaeontology, no. 23, p. 249-254.

0671 Logan, W. E., and Ilunt, T. S., 1854, On the chemical composition of recent and fossil lingulae and some other shells: American

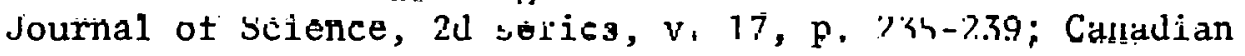
Journal , v. 2, p. 264-265.

0672 Loomis, F. B., 1903, The dwarf fauna of the pyrite layer at the horizon of the Tully Limestone in western New York: New York State Museum Bulletin 69, p. 892-920.

0673 Loranger, D. M., 1954, Ireton microfossil zones of central and northeastern Alberta: in Clark, L. M. (ed.), Western Canada Sedimentary Basin - A symposium: Ralph Leslie Rutherford Memorial Volume, Tulsa, American Association of Petroleum Geologists, p. 182-203.

0674 Lyon, S., and Casseday, S. A., 1859, Description of nine species of Crinoidea from the Subcarboniferous rocks of Indiana and Kentucky: American Journal of Science, $2 d$ series, v. 28, p. 233-240.

0675 McAlester, A. L., 1962, Upper Devonian pelecypods of the New York Chemung Stage: Yale Peabody Museum of Natural History Bulletin, v. 16, 88 pp.

0676 , 1963, Pelecypods as stratigraphic guides in the Appalachian Upper Devonian: Geological Society of Americi Bulletin, v. 74, p. $1209-1224$.

0677 _ 1970, Animal extinctions, oxy.gen consumption, and atmosphere history: Jürnal of paleontology, v. 44, p. 405-409.

0678 McCave, I. N., 1969, Correlation using a sedimentological model of part of the Hamilton Group (Middle Devonian), New York state: Amcrican Journal of Science, v. 267, p. 567-591.

0679 McFarlan, A. C., 1943, Geology of Kentucky: Lexington, University of Kentucky, p. 50-56.

0680 McFarlan, A. C., and White, W. H., 1952, Boyle - Dutfin - Ohio Shale relationships: Kentucky Geological Survey Bulletin, series 9, v. $10,24 \mathrm{pp}$.

0681 McGhee, G. R., Jr., 1976, Late Devonian benthic marine communities of the central Appalachian Allegheny front: Lethaia, v. 9, p. 111-136.

0682 _. 1977a, Paleocommunity evolution: an examination of the Frasnian (Late Devonian) of the eastern United States (abstr.): Geologicai Society of America Abstracts with Programs, v. 9, p. 299-300. 
0683 McGhee, G. R., Jr., 1977b, The Frasnian-Famennian (Late Devonian) boundary within the Foreknobs Formation, Maryland and West Virginia: Geological Society of America Bulletin, v. 88, p. 806-808.

0684 , 1979, The benthic marine fauna of the Foreknobs Formation (Late Devonian) in Maryland, West Virginia, and Virginia: in Avary, K. L. (ed.), Devonian Clastics in West Virginia and Maryland, Field Trip Guide, Morgantown, West Virginia, West Virginia Geological and Economic Survey, p. 93-100.

0685 , 1980, Late Frasnian (Devonian) benthic marine communities of New York and the central Appalachians: Geological Society of America Abstracts with Programs, v. 12, p. 73.

0686 McGregor, D. J., 1954, Stratigraphic analysis of Upper Devonian and Mississippian rocks in Michigan Basin: America Association of Petroleum Geologists Bulletin, v. 38, p. 2324-2356.

0687 __ 1960, Devonion spores from Melville Island, Canadian Arctic Archipelago: Palaeontology, v. 3, p. 26-44.

0688 McGregor, D. J., and Uyeno, T. T., 1972, Devonian spores and conodonts of Melville and Bathurst Islands, District of Frankline: Geological Survey of Canada Paper 71-13, $36 \mathrm{pp}$.

0689 McGregor, D. J., 1979a, Devonian miospores of North America: Palynology, v. 3, p. 31-52.

$0690 \ldots$ _ 1979b, Spores in Devonian stratigraphical correlation: in House, M. R., Scrutton, C. T., and Bassett, M. G. (eds.), The Devonian System, Special Papers in Palaeontology, no. 23, p. $163-184$.

0691 McIntosh, G. C., 1978, Psuedoplanktonic crinoid colonies attached to Upper Devonian (Frasnian) logs (abstr.): Geological Society of America Abstracts with Programs, v. 10, p. 453.

0692 McKee, R. H., 1925, Shale oil: New York, Chemical Catalog Co., $326 \mathrm{pp}$.

0693 McKelvey, V. E., 1959, Relation of upwelling marine waters to phosphorite and oil (abstr.): Geological Society of America Bulletin, v. 70, p. 1783-1784.

$0694+$, 1967, Phosphate deposits: U.S. Geological Survey Bulletin 1252-D, P. D1-D20.

0695 McKerrow, W. S., and Ziegler, A. M., Paleozoic oceans: Nature, Physical Science, v. 240, p. 92-94.

0696 McLaren, D. J., 1954, Upper Devonian Rhynchonellid zones in the Canadian Rocky Mountains: in Clark, L. M. (ed.), Western Canada Sedimentary Basin: A symposium: Ralph Leslie Rutherford Memorial Volume, American Association of Petroleum Geologists, Tulsa, p. 159.

0697 McLaughlin, R. E., and Reaugh, A. B., 1974, Palynomorphs in the Chattanooga black shale in Tennessee (abstr.): Geological Society of America Abstracts with Programs, v. 6, p. 381,

0698 Ma, T. Y. H., 1956, A reinvestigation of climate and relative positions of continents during the Devonian: Research on the Past Climate and Continental Drift, v. 9, 116 pp.*

0699 , 1960,. The cause of late Paleozoic glaciation in Australia and South America: International Geologic Congress, 21st Session Report, Copenhagen, Part 12, p...111-117. 
0700 Maack, R., 1960, Zur Palaogeographie des Gondwanalandes: Internationa1 Geologic Congress, 21st Session Report, Copenhagen, part 12, p. 35-55.

0701 Macauley, G., Penner, D. G., Proctor, R. M., and Tisdal1, W. H., 1964, Chapter 7, Carboniferous: in McCrossan, R. G., and Glaister, R. P. (eds.), Geological history of western Canada, Calgary, Alberta, Alberta Society of Petroleum Geologists, p. 89-112.

0702 Maher, S. W., 1956, Sandy zones in the Chattanooga of the eastern Highland Rim, Tennessee: Journal of Sedimentary Petrology, v. 26, p. 338-342.

0703 Malmberg, G. T., and Downing, H. T., 1957, Devonian System: in Geology and Ground-water resources of Madison County, Alabama: Geological Survey of Alabama County Report 3, p. 3033.

0704 Malzahn, E., 1957, Devonishces Glazial im Staate Piaui (Brasilien), ein neur Beitrag zur Eiszeit des Devons: Beih. Geol. Jahrb., v. 25, p. $1-31 . *$

0705 Maroney, D., and Orr, R. W., 1974, Ctenocularia delhiensis, a new species of the Conulata from the New Albany Shale (Upper Devonian) at Delphi, Indiana: Indiana Geological Survey Occassional Paper, no. $7,6 \mathrm{pp}$.

0706 Marsh, 0.C., 1869, Amphibian footprints from the Devonian: American Journal of Science, 4th series, v. 2, p. 274-275.

0707 Martin, S. J., and Zielinski, R. E., 1978, A biostratigraphic analysis of core samples from wells drilled in the Devonian shale interval of the Appalachian and Illinois basins: U.S. Department of Energy, Eastern Gas Shales Project, Open File Report 113, p. 9-22.

0708 Mason, David, 1962, Pyritized microfossils from the Upper Devonian black shale of southwestern Ontario and southorn Michigan (abstr.): Canadian Mining Journal, v. 83, p. 95.

0709 Mather, K. F., 1920, Oil and gas resources of the northeastern part of Simner County, Tennessee: Tennessee State Geological Survey Bulletin 24. Part 2-B, $39 \mathrm{pp}$.*

0710 Mathew, G. F., 1906, New species and a new genus of Devonian plants: Natural History Society of New Brunswick Bulletin, v. 24, (5 part 4), p. 393-398.*

0711 Mathews; G. B., 1940, New Lepidostrobi from central United States: Botanical Gazette, v. 102, p. 26-49.

0712 Matten, L. C., 1972, Callixylon from the Maury Formation (Lower Mississippian) of Tennessee: Journal of Paleontology, v. 46, p. $711-713$.

0713 Maughn, E. K., 1976, Geologic Map of the Roxana quadrangle, I.ctcher and Harlan Counties, Kentucky: U.S. Geological Survey Geologic Quadrangle Map GQ-1299.

0714 Maxwe11, C. H., 1965, Geologic Map of the Dunnville quadrangle, Kentucky: U.S. Geological Survey Geologic Quadrangle Map GQ-367.

0715 Meek, F. B., 1871, Dcscription of new species nf invertebrate fossils from the Carboniferous and Devonian rocks of Ohio: Academy of Natural Science of Philadelphia Proceedings for 1871, p. 57-93.* 
0716 Meek, F. B., 187.5, A report on some of the invertebrate fossils of the Waverly Group and Coal Measures of Ohio: Ohio Geologica1 Survey Report 2, part 2, Paleontology, p. 269-347.

0717 Meek, F. B., and Worthen, A. H., 1861, Age of the Goniatite limestone at Rockford, Indiana, and its relation to the "black slate" of the western states, and to some of the succeeding rocks above the latter: America Journal of Science, $2 \mathrm{~d}$ series, v. 32, p. 167-177, 288.

0718 , 1865, Contributions to the paleontology of Illinois and other western states: Philadelphia Academy of Natural Science Proceedings, v. 13, p. 245-273.

0719 _ 1866, Descriptions of Paleozoic fossils from the Silurian, Devonian, and Carboniferous rocks of Illinois, and other western states: Chicago Academy of Science Proceedings, v. 1, p. $11-23$.*

$0720 \ldots$ _ 1868, Devonian species: in Part II, Paleontology: Geological Survey of Illinois, Volume III, p. 393-449.

0721 Meh1, M. G., 1960, The relationships of the base of the Mississippian System in Missouri: Denison University Scientific Laboratories Journal; v. 45, p. 57-107.

0722 _ 1961a, Basal relationships of the Mississippian in northeastern Missouri: Missouri Division of Geological Survey and Water Resources Report of Investigations 27, p. 89-91.

0723 , 1961b, Basal relationships of the Mississippian in northeastern Missouri: in Malone, Donald J. (ed.), Kansas Geological Society Guidebook, 26th Annual Field Conference, p. 8994.

0724 Meh1, M. G., and Shaffer, B., 1961, Sporangites as 'horizon markers': in Malone Donald J. (ed.), Kansas Geological Society Guidebook, 26th Annual Field Conference, p. 95-99.

0725

Melhorn, W. N., 1958, Revision of the Mississippian-Devonian boundaries in White and Benton Counties, Indiana: Indiana Academy of Science Proceedings, v. 67, p. 194-198.

0726 Meyerhoff, A. A., 1970, Continental drift: Implications of palaeomagnetic studies, meterology, physical oceanography, and climatology: Journal of Geology, v. 78, p. 1-51.

0727 Miller, A. K., 1938, Devonian ammonoids of America: Geological Society of America Special Paper 14, $262 \mathrm{pp}$ :

0728 Miller, A. K., and Carmer, A. M., 1933, Devonian foraminifera from Iowa: Journal of Paleontology, v. 7, p. 423-431.

0729 Miller, A. K., and Furnish, W. M., 1937, Paleoecology of the Paleozoic cephalopods: National Research Council, Division of Geology and Geography, Report of the Committee on Paleoecology, 1936-1937, p. 54-63.

0730 Miller, A. K., and Warren, P. S., 1936, A Timanites from Upper Devonian leds of America: Joumal of Paleontology, v. 10 , p. 632-636.

0731 Miller, A. K., aind Youngquist, Walter, 1947, Conodonts from the type section of the Sweetland Creek Shale in Iowa: Journal of Paleontology, v. 21, p. 501-517.

0732 Miller, A. M., 1916, Some historic fish remains from Vanceburg, Kentucky (abstr.): Science, new series, v. 44, p. 71-72. 
0733 Miller, A. M., 1919, Geology of Kentucky: Kentucky Department of Geology and Forestry, series 5, Bulletin 2, p. 84-87.

0734 Miller, M. L., 1978, A Petrographic Study of the Upper DevonianLower Mississippian B1ack Shales in Eastern Kentucky: Unpublished Masters thesis, University of Kentucky, Lexington, $107 \mathrm{pp}$.

0735 Miller, R. C., 1970, Analysis of sandstones in the Dowelltown Member of the Chattanooga Shale, Macon County, Tennessee, and vicinity: Compass, v. 47, no. 2, p. 84-89.

0736

Miller, S. A., 1877, The American Palaeozoic Fossils: A Catalogue, Cincinnati, Cincinnati Times Co., 334 pp.

$0737 \ldots$, 1889, North American Geology and Paleontology: Cincinnati, Western Methodist Book Concern, $718 \mathrm{pp}$.

0738 Miller, S. A., and Gurley, W. F. E., 1894, Upper Devonian and Niagara Crinoids: Illinois State Museum of Natural History Bulletin, v. 4, 37 pp.

0739 Milner, H. B., 1940, Oil Shale: Sedimentary Petrology, 3d edition, London, Thomas Murby and Co., p. 413-414.

0740 Miser, H. D., 1944, The Devonian System in Arkansas and Oklahoma: in Illinois State Geological Survey Bulletin 68, p. 132-138.

0741 Mitche11, J. L., and Bagby, Robert, 1969, The sedimentary environment of conodonts in the Chattanooga Shale, Catoosa County, Georgia (abstr.): Georgia Academy of Science Bulletin, v. 27, p. 91-92.

0742 Mixer, F. K., 1896, The discovery of a new fish fauna from the Devonian rocks of southwestern New York: American Geologist, v. 18, p. 223 .

0743 Monroe, E., and Teller, E., 1899, The fauna of the Devonian formation at Milwaukee, Wis.: Journal of Geology, v. 7, p. 272283.

0744 Moodie, R. L., 1931, The geologic succession of life in Kentucky: Kentucky Geological Survey, Series 6, v. 36, p. 15-21, 234235.

0745 Moore, R. C., 1928, Early Mississippian formations in Missouri: Missouri Bureau of Geology and Mines, $2 d$ series, v. 21, p. 34-42, 79-82, 110-118.

0746 Morel, P., and Irving, E., 1978, Tentative paleocontinental maps for the early Phanerozoic and Proterozoic: Journal of Geology, v. 86, p. 535-561.

0747 Morris, R. H., 1965a, Geologic Map of the Charters quadrangle, Kentucky: U.S. Geological Survey Geologic Quadrangle Map GQे-293.

0748 , 1965b, Geologic Map of the Burtonville quadrangle; Kentucky: U.S. Geological Survey Geologic Quadrangle Map GQ-396.

0749 _ 1965c, Geologic Man of the Stricklett quadrangle, Northeastern Kentucky: U.S. Geological Survey Geologic Quadrangle Map GQ-364.

$0750 \ldots$, 1966a, Geologic Map of the Head of the Grassy quadrangle, Lewis County, Kentucky: U.S. Geological Survey Geologic Quadrangle Map GQ 481.

$0751 \ldots$ 1966b, Geologic Map of parts of the Concord and Buena Vista quadrangles, Lewis County, Kentucky: U.S. Geological Survey Geologic Quadrangle Map GQ-525. 
0752 Morris, R. H., and Pierce, K. L., 1967, Geologic Map of the Vanceburg quadrangle, Kentucky-Ohio: U.S. Geological Survey Geologic Quadrangle Map GQ-598.

0753 Morse, W. C., 1928, Paleozoic rocks of Mississippi: Journal of Geology, v. 36, p. 31-43.

0754 Morse, W. C., and Foerste, A. F., 1909, The Waverly formations of east-central Kentucky: Journal of Geology, v. 17, p. 164177 .

0755 _ 1912a, Preliminary report on the Waverlian formations of east central Kentucky: Kentucky Geological Survey Bulletin $16,76 \mathrm{pp}$.

$0756 \ldots$ _ 1912b, The Waverlian formations of east-central Kentucky and their economic values: Kentucky Geological Survey Bulletin, no. $16,76 \mathrm{pp}$.

0757 Mound, M. C., 1964, New names for condont homonyms: Journal of Paleontology, v. 38, p. 786.

$0758 \ldots$ 1967, Conodonts and biostratigraphic zones from the subsurface Upper Devonian of Alberta: in Oswald, D. H. (ed.) International Symposium on the Devonian, 1967 Proceedings, Calgary, Alberta, Alberta Society of Petroleum Geologists, v. 2, p. 653-672.

$0759 \ldots$, 1968, Upper Devonian conodonts from southern Alberta: Journal of Paleontology, v. 42, p. 444-524.

0760 Miiller, K. J., 1962, A conodont fauna from the Banff Formation, western Canada: Journal of Paleontology, v. 36, p. 13871391.

0761 Muller, K. J., and Muller, E. M., 1957, Early Upper Devonian (Independence) conodonts from Iowa: Journal of Paleontology, v. 31, p. 1069-1108.

0762 Murphy, J. L., 1973, Protosalvinia (Foertia) zone in the Upper Devonian sequence of eastern Ohio, northwestern Pennsylvania, and western New York: Geological Society of America Bulletin, v. 84, p. 3405-3410.

0763 Neal, Don, 1977, Fossils from the Devonian shale: Mountain State Geology, West Virginia Geological and Economic Survey, p. 23.

0764 Nelson, W. H., 1962, Geology, of the Holland quadrangle, KentuckyTennessee: U.S. Geological Survey Geologic Quadrangle Map GQ-174.

0765 Nelson, S. J., 1970, The face of time, the geological history of western Canada: Calgary, Alberta, Alberta Society of Petroleum Geologists, 133 pp.

0766 Nettleroth, H., 1889, Kentucky fossil shells; a monograph of the fossil shells of the Silurian and Devonian rocks of Kentucky: Kentucky Geological Survey Miscellaneous Geological Reports, v. 12, 245 pp.

0767 Newberry, J. S., 1857, New Fossil fishes from the Devonian rocks of Ohio: American Journal of Science, 2d series, v. 24, p. 147-149.

0768 , 1868, On some remarkable fossil fishes discovered by Rev. H. Harzer, in the black shale (Devonian) at Delaware, Ohio: Proceedings of the American Association for the Advancement of Science, v. 16, p. $146-147$. 
0769 Newberry, J. S., 1871a, Notes on some new genera and species of fossil fishes from the Devonian rocks of Ohio: Lyceum of Natural History of New York Proceedings, v. 1, p. 152-153.* $1871 \mathrm{~b}$, Report of progress of the geological survey of Ohio in 1869: Columbus, Ohio, Nevins and Meyers, State Printers, $176 \mathrm{pp}$.

0771 , 1873a, Devonian system, in Geology and paleontology, v. 1,

0772 part 1, Geological Survey of Ohio, p. 140-167.

0773 , 1873b, Description of fossil fishes: Geology and Paleontology, v. 1, part 2, Geological Survey of Ohio, p. 247-355.

$0774 \ldots$ _ 1874b, (On Dinichthys terrelli from the Huron Shale of , 1974a, Report of the Geological Survey of Ohio; Paleontology: Ohio Geological Survey, v. 2, part 2, $435 \mathrm{pp}$. Lorain Co., Ohio): Lyceum of Natural History of New York Proceedings, v. 2, no. 4, p. 149-151.*

0775 , 1875, Descriptions of fossil fishes: Ohio Geological Survey, Report 2, part 2, Paleontology, p. 1-64.

0776 , 1878, Descriptions of new Paleozoic fishes: New York Academy of Science Annals, v. 1, p. 188-192.

0777

0778 , 1883a, Fossil fishes from the Devonian rocks of Ohio: New York Academy of Science Transactions, v. 2, p. 145.* , $1883 \mathrm{~b}$, On the origin of carbonaccous matter in bituminous shales: New York Academy of Science Annals, v. 2, p. 357369 .*

$0779 \ldots$ 1884, On the recent discovery of new and remarkable fossil fishes in the Carboniferous and Devonian rocks of Ohio and Indiana (abstr.): British Association for the Advancement of Science Report, v. 54, p. 724-725.*

$0780 \ldots 1885 a$, The relations of Dinichthys, as shown by complete crania recently discovered by Jay Terrell in the Huron Shale of Ohio: New York Academy of Science Transactions, v. 3, p. 20 *

0781 , 1885b, Description of some gigantic placoderm fishes recently discovcred in the llevonian of Oliio: New York Academy of Science Transactions, v. 5, p. 25-28.*

0782 , 1887, Description of a new species of Titanichthys (abstr.):

078.3

0784 New York Academy of Science Transactions, v. 6, p. 164-165.* , 1888a, On the fossil fishes of the Erie Shale of Ohio (abstr.): New York Academy of Science Transactions, v. 7, p. $178-180$.*

\section{(20)}

0785 $1888 \mathrm{~b}$, Sur les restes de grands poissons fossils recémment découverts dans les roches dévoniennes de 1 'Amerique du Nord (Dinichthys, Titanichthys): International Geological Congress III, BerIin 1885 Proceedings, Comptes Rendu, p. 11-14.*

\section{6} , loby, Dcvoniun plants from nhio: Journal of the Cincinnati Society of Natural History, v. 12, p. 53-56.

0787 Newberry, J. S., and Worthen, A. H., 1870, Description of fossil vertebrates: Illinois Geological Survey, v. 4, p. 343-374.* 
Newton, C. R., 1979a, Aerobic, dysaerobic, and anaerobic facies within the Needmore Shale (Lower and Middle Devonian): in Dennison, John M., and others (eds.), Devonian Shales in South-Central Pennsylvania and Maryland, 44th Annual Field Conference for Pennsylvania Geologists, Guidebook, Harrisburg, Pennsylvania, Bureau of Topographic and Geologic Survey, p. 56-60.

$0789 \ldots$, 1979b, Biofacies patterns in the Needmore Shale: Paleoenvironmental and paleobathymetric implications: in Avary, K. L. (ed.), Devonian Clastics in West Virginia and Maryland, Field Trip Guide, Morgantown, West Virginia Geological and Economic Survey, p. 77-82.

0790 Newton, E. J., 1875, On 'Tasmanite' and Australian 'white coal': Geological Magazine, series. 2, v. 2, p. 337-342.

0791 Niklas, K. J., 1976a, Chemotaxonomy of Prototaxites and evidence for possible terrestrial adaptation: Review of Palaeobotany and Palynology, v. 22, p. 1-17.

0792 _ 1976b, Organic chemistry of Protosalvinia (Foerstia) from the Chattanooga and New Albany shales: Review of Palaeobotany and Palynology, v. 22, p. 265-279.

0793 Niklas, K. J., and Carozzi, A. V., 1976, Morphology and palaeoecology of Protosalvinia from the Upper Devonian (Famennian) of the Amazon Basin of Brazil: Palaeontographica, Abt. B, v. 155, p. $1-30$.*

0794 Niklas, K. J., and Phillips, T. L., 1976, Morphology of Protosalvinia from the Upper Devonian of Ohio and Kentucky: American Journal of Botany, v. 63, p. 9-29.

0795 Norris, A. W., 1979, Devonian in the western hemisphere: in Robison, R. A., and Teichert, Curt (eds.), Treatise on invertebrate paleontology, Part A, Introduction, Boulder, Geological Society of America, p. A218-A253.

0796 Norris, G., and Sargeant, W. A. S., 1965, A descriptive index of genera of fossil Dinophyceae and Acritarcha: Palaeontological Bulletin of Wellington, v. $40,72 \mathrm{pp}$.*

0797 Norwood, J. G., and Owen, D. D., 1846a, (On a fossil fish, Macropetalichthys rapheidolabris, from southern Indiana: Boston Society of Natural History Proceedings, v. 2, p. 102, 116.*

$0798 \ldots$ _ 1846b, Description of a new fossil fish from the Paleozoic rocks of Indiana: Allerican Journal of Science, $2 \mathrm{~d}$ series, v. 1, p. 367-371.

0799 Nosow, Edmund, 1959, Stratigraphy of Nelson County and adjacent areas: Geological Society of Kentucky, Field Trip Guidebook, Kentucky Geological Survey, Figs. 8, 13, 14.

0800 Nye, 0. B., Brower, J. C., and Wilson, Steven E., 1975, Hitchhiking clams in the Marcellus sea: Bulletins of American Paleontology, v. 67, p. 287-298.

0801 0liver, W. A., 1964, A new species of the rugose coral genus Nalivkinella riom the Middle Vevonian of eastern Pennsylvania: Journal of Paleontology, v. 38, p. 866-876. 
0802 Oliver, W. A., de Witt, Wallace, Jr., Dennison;, J. M., Hoskins, D. M., and Huddle, J. W., 1967, Devonian of the Appalachian basin, U.S.: in Oswald,.D.H. (ed.), International Symposium on the Devonian, 1967 Proceedings, Calgary, Alberta, Alberta Society of Petroleum Geologists, v. 1, p. 1001-1040.

0803 01sson, Axel, 1912, New and interesting fossils from the Devonian of New York: Bulletins of American Paleontology, v. 5, no. 23, 7 pp.*

0804 Orr, W. R., and Klapper, Gilbert, 1968, Two new conodont species from Middle - Upper Devonian boundary beds of Indiana and New York: Journal of Paleontology, v. 42, p. 1066-1075.

0805 Ortmann, A. E., 1882, Source of bituminous matter in the Devonian and Subcarboniferous black shales of Ohio: American Journal of Science, 3d series,. v. 24, p. 171-174.

0806 , 1897, The systematic position of Crangopsis vermiformis (Meek): from the subcarboniferous rocks of Kentucky: American Journal of Science, 4th series, v. 4, p. 283-289.

0807 Orton, Edward, 1882, A source of the bituminous matter in the Devonian and subcarboniferous black shales of Ohio: American Journal of Science, 3d series;, v. 24, p. 171-175.

0808 , 1883, A source of bituminous matter of the black shales of Ohio: Proceedings of the American Association for the Advancement of Science, 31st Meeting, p. 373-384.

0809 , 1888, Report of the Geological Survey of Ohio; Economic geology: Ohio Geological Survey, v. 6, $831 \mathrm{pp}$.

0810

0811 , 1889, Discovery of sporocarps in the Ohio Shale (abstr.): Proceedings of the American Association for the Advancement of Science, v. 37, p. 179-181. , 1893, Report of the Geological Survey of Ohio:. Economic gcology, archaenlogy, hotany, paleontology: Ohio Geological Survey, v. 7, $699 \mathrm{pp}$.

0812 , I896, The geography and geology of Ohio: in Howe, Henry, Historical collections of Ohiu: Norwalk, Ohio, Laning Printing Co., v. 1, $996 \mathrm{pp}$.

0813 Oswald, D. H. (ed.), 1968d, b, Intcrututional Sympnsium on the. Devonian System, 1967 Proceedings, Calgary, Alberta, Alberta Society of Petroleum Geologists, a) v. 1, 1055 pp., b) v. 2, 1377 pp.

0814 Owen, D. D., 1856, Black Lingula shale: in Report of the lejological Survey of Kentucky, 1854, 1855, v. 1, p. 91-95.

0815 Paine, R. T., 1963, Ecolngy of the brachiopod Glottidia pyrimidata: Ecology Monographs, v. 33, p. 187-213.

$0816 \ldots$ _ 1970, The sediment occupied by recent lingulid brachiopods and some paleoecological implications: Palaeogeography, Palaeoc1imatology, and $\mathrm{Palaevecology,} \mathrm{v.} \mathrm{7,} \mathrm{p.} \mathrm{21.-31.}$

0817 Palmer, E. L., 1971, Fossils: Chicago, D. C. Heath and Co., p. 64-71.

0818 Pamenter, C. B., 1956, Imitoceras from the Exshaw Formation of Alberta: Journal of Paleontology, v. 30, p. 965-966.

0819 Park, D. E., and Croneis, C., 1969, Origin of the Caballos and Arkansas novaculite formations: American Association of Petroleum Geologists Bulletin, v. 53, p. 94-111. 
0820 Parke, Mary, 1969, The genus Pachysphaera (Prasinophyceae): in Barnes, Harold (ed.), Some contemporary studies in marine science, London, George Allen and Unwin, Ltd., p. 555-563.

0821 Patchen, D. G., and Dugolinsky, B. K., 1979, Guidebook, Middle and Upper Devonian Clastics, central and western New York state: U.S. Department of Energy, Eastern Gas Shales Project, Morgantown, West Virginia, $169 \mathrm{pp}$.

0822 Peck, J. H., 1967, Geologic map of the Tollesboro quadrangle, Lewis and Fleming Counties, Kentucky: U.S. Geological Survey. Geologic Quadrangle Map GQ-661.

0823 Peck, J. H., and Pierce, K. L., 1966, Geologic map of the Manchester Islands quadrangle, Lewis County, Kentucky: U.S. Geological Survey Geologic Quadrangle Map GQ-581.

0824 Peck, J. H., and Weir, G. W., 1968, Stops 1-6, Kentucky itenerary, Saturday, May 18, 1968: in Geological Aspects of the Maysville-Portsmouth region, Southern Ohio and northeastern Kentucky, Ohio Geological Society - Geological Society of Kentucky Joint Field Conference 1968, Kentucky Geological Survey, p. 46-62.

0825 Pelzer, E. E., 1966, Mineralogy, geochemistry, and stratigraphy of the Besa River Shale, British Columbia: Bulletin of Canadian Petroleum Geology, v. 14, p. 273-321.

0826 Penhallow, D. P., 1889, On Nematophyton and allied forms from the Devonian (Erian) of Gaspe and Baie des Chaleurs: Royal Society of Canada Proceedings and Transactions, v. 6, part iv, p. 27-47. * , 1890, Notes on Devonian plants: Royal Society of Canada

0828 Proceedings and Transactions, v. 7, part i.v, p. 19-30.* , 1893a, Notes on Erian (Devonian) plants from New York and Pennsylvania: U.S. National Museum Proceedings, v. 16, p. 105-114.* , 1893b, Notes on Nematophyton crassum: U.S. National Museum Proceedings, v. 16, p. 115-118.* , 1896, Nematophyton ortoni n. sp.: Annals of Botany, v. $10, \mathrm{p}$. 41-49.* , 1900, Notes on American species of Dadoxylon: 'Transactions of the Royal Society of Canada, $2 \mathrm{~d}$ Series, v: 6, section 4 , p. 51-97.

0832 Pepper, J. F., de Witt, Wallace, Jr., and Demarest, D. F., 1954, Geology of the Bedford Shale and Berea Sandstone in the Appalachian Basin: U.S. Geological Survey Professional Paper $259,111 \mathrm{pp}$.

0833 Peppers, R. A., and Damberger, H. H., 1969, Palynology and petrography of a Middle Devonian coal in Illinois: Illinois State. Geological Survey Circular 445, 36 pp.

0834 Perciva1, I. G., 1978, Inarticulate brachiopods from the Late Ordovician of New South Wales and their paleoecological significance: Alcheringa, v. 2, p. 117-141.

0835 Peterson, D. M:, 1974, Geology of western New York state: New York Geological Association Field Trip Guidebook, 46th Annual Meeting. 
0836 Peterson, W. L., 1966, Geologic map of the Nelsonville quadrangle, central Kentucky: U.S. Geological Survey Geologic Quadrangle Map GQ-564.

0837 _ 1967, Geologic map of the Lebanon Junction quadrangle, central Kentucky: U.S. Geological Survey Geologic Quadrangle Map GQ-603.

$0838 \ldots$ 1968, Geologic map of the Cravens quadrangle, Bullitt and Nelson Counties, Kentucky: U.S. Geological Survey Geologic Quadrangle Map GQ-737.

0839 , 1969, Geologic map of the Bardstown quadrangle, central kentucky: U.S. Geological Survey Geologic Quadrangle Map GQ825 .

0840 , 1972, Geologic map of the Loretto quadrangle, central Kentucky: U.S. Geological Survey Geologic Quadrangle Map GQ-1034..

0841 Pettijohn, F. J., 1957, Black shales: 1n Sedimentary Rocks: New

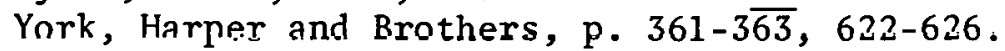

0842 Feetitt, J. M., alld Beck, C. B.), 1968, Archaeosperma arnoldii a copulate seed from the Upper Devonian of North America: University of Michigan Museum Paleontology Contributions, v. 22, p. 139-154.

0843 Peyer, Bernhard, 1968, Placodermi and acanthodii: in Comparative - Odontology: Chicago, University of Chicago Press, p. 30-34.

0844 Philip, G. M., and McDonald, L., 1975, A provisional phylogeny for some reconstructed Late Devonian polygnathid conodont apparatuses: Alcheringa, v. 1, p. 97-107.

0845 Philley, J. C., Hylbert, D. K., and Hoge, H. P., 1974, Geologic map of the Cranston quadrangle, northeastern Kentucky: U.S. Geological Survey Geologic Quadrangle Map GQ-1212.

0846 Phillips, T. L., Andrews, H. N., and Gense1, P. G., 1972, Two hetcrosporous species of Ariliaeupleris frum llie Devunian of West Virginia: Palaeontographica, Abt. B, v. 139, p. 47-71.*

0847 Phillips, T. L., Niklas, K. J., and Andrews, H: N. , 1972, Morphology and vertical distribution of Protosalvinia (Foerstia) from the New Albany Shale (Upper Devonian): Review of Palaeobotany and Palynology, v. 14, p. 171-196.

0848 Piper, D. Z., and Codispoti, L. A., 1975, Marine phosphorite deposits and the nitrogen cycle: Science, New York, v. 188, p. $15=18$.

U849 Pohl, E. R., 1926, Palentonlngis zonnes of the upper Hamilton Group in west-central New York: Unpublished Masters Essay, George Washington University, Washington, D.C.

0850 _. 1930a, The black shale series of central Tennessee (abstr.): American. Journal of Science, 5 th series, v. 20, p. $151-152$.

0851 1930b, Devonian formations of the Mississinpi basin: Tennessee Academy of Science Journa1, v. 5, p. 54-63.

0852 Pollock, C. A., 1968, Lower Upper Devonian conodonts from Alberta, Canada: Journal of Paleontology, v. 42, p. 415-443.

0853 Potonie, R.; and Rehne1t, K., 1971, Aspects of sporin: in Brooks, J., and others (eds.), Sporopollenin: New York, Aca đemic Press, p. 295-304.

0854 Potter, P. E., Maynard, J. B., Pryor, W. A., 1977, Geology of argillaceous sediments: an annotated and illustrated bibliography: Morgantown, West Virginia, Morgantown Energy Research Center, MERC/CR-77/8, $134 \mathrm{pp}$. 
0855 Potter, P. E., Maynard, J. B., and Pryor, W. A., 1980, Final report of special geological, geochemical, and petrological studies of the Devonian shales in the Appalachian basin (Eastern Gas Shales Project; U.S. Department of Energy): Cincinnati, University of Cincinnati, $86 \mathrm{pp}$.

0856 Prosser, C. S., 1891, The geological position of the Catskill Group: American Geologist, v. 7, p. 351-366.

0857 , 1892, The Devonian System of eastern Pennsylvania: American Journal of Science, 3d series;. v. 44, p. 210-221.

0858 , 1893, The upper Hamilton and Portage stages of central and eastern New York: American Journal of Science, 3d series, v. 46, p. 212-230.

$0859 \quad, 1894$, The Devonian system of eastern Pennsylvania and New York: U.S. Geological Survey Bulletin 120, p. 1-81.

0860 1897, The classification and distribution of the Hamilton and Chemung series of central and eastern New York: New York State Geologist, 15th Annual Report, p. 12-13, 83-222; New York State Museum, 49th Annual Report, v. 2, p. 12-13, p. 83-222.*

0861 , 1901, The classification of the Waverly series of central Ohio: Journal of Geology, v. 9, p. 205-231.

0862 , 1902, The Sunbury Shale of Ohio: Journal of Geology, v. 10, p. $262-312$.

0863 , 1903, The nomenclature of the Ohio geological formations: Journal of Geology, v. 11, p. 519-546.

0864 , 1904, Description and correlation of the Romney Formation of Maryland: Journal of Geology; v. 12, p. 361-372:

0865 , 1912a, The Devonian and Mississippian formations of northeastern Ohio: Ohio Geological Survey, 4th series, Bulletin 15 , p. 509-548.

0866 , 1912b, The disconformity between the Bedford and Berea formations in central Ohio: Journal of Geology, v. 20, p. 585-604.

0867 , 1913, The Huron and Cleveland shales of northern Ohio: Journal of Geology, v. 21, p. 323-362.

0868 , 1915, The Middle and Upper Devonian of the Romney, W. Va. region: Journal of Geology, v. 23, p. 11-26.

0869 Prosser, C. S., and Cumings, E. R., 1904, The Waverly formations of Eenlral Ohio: American Geologist, v. 34, p. 335-361.

0870 Prosser, C. S., Kindle, E. M., and Swartz, C. K., 1913, The Middle Devonian deposits of Maryland: in Middle and Upper Devonian, Maryland Geological Survey, v. 6, part 1, p. 23-335.

0871 Prosser, C. S.; and Swartz, C. K., 1913, The Upper Devonian deposits of Maryland: in Middle and Upper Devonian, Maryland Geological Survey, v. 6, part 1, p. 339-700.

0872 Provo, L. J., Kepferle, R. C., and Potter, P. E., 1977, ThreeLick Bed: Useful stratigraphic marker in Upper Devonian shale in eastern Kentucky and adjacent areas of Uhio, West Virginia, and Tennessee: Morgantown, West Virginia, Morgantown Energy Research Center MERC/CR-77/2, 56 pp.

0873 Purdue, A. H., and Miser, H. D., 1916, Eureka Springs-Harrison Folio, Arkansas-Missouri: U.S. Geological Survey Geologic Atlas of the United States, Folio 202, 22 pp. 
0874 Rabien, Arnold, 1954, Zur Taxionomie und Chronologie der Oberdevonishcen Ostracoden: Abhandlungen des Hessischen Landesamtes fur Bodenforschung, v. 9, $268 \mathrm{pp}$.

0875 Raymond, P. E., 1904, The Tropidoleptus fauna at Canadaigua Lake, N.Y., with the ontogeny of twenty species: Carnegie Museum Anna1s, v. 3, p. 79-177.*

0876 , 1942, The pigment in black and red sediments: American Journal of Science, v. 240, p. 658-669.

0877 Read, C. B., 1935, An occurrence of the genus Cladoxylon Unger, in North America: Journal of the Washington Academy of Science, v. 25, p. 493-497.

0878 1936a, A Devonian flora from Kentucky: Journal of Paleontology, v. 10, p. 215-227.

0879

0880 , 1936b, The flora of the New Albany Shale: Part I, Diichnia kentuckiensis, a new representative of the Calamopityeae: U.S. Geolugical Survey Professional Paper 185-Il, p. 149-161.

0882 1937, The flora of the New Albany Shale: Part 2, 'l'he Calamopityeae and their relationships: U.S. Geological Survey Professional Paper 186-F, p. 81-104.

\section{1}

Read, C. B., and Campbe11, Guy, 1939, Preliminary account of the New Albany Shale flora: American Midland Naturalist, v. 21, p. 435-453.

Read, C. B., and Mamay, S. R., 1964, Upper Paleozoic floral zones and floral provinces of the United States: U.S. Geological Survey Professiona1 Paper 454-K, $35 \mathrm{pp}$.

0883 Reaugh, A. B., and McLaughlin,.R. E., 1975, Environment-related palynomorph groups in the Chattanooga black shale (abstr.): Geological Society of America Abstracts with Programs, v. 7, p. 1239 .

0884 Reeves, J. R., 1922, Preliminary report on the ofl shales of Indiana: Indiana Department of Conservation Publication 21, part 6, p. $1071=1074$.

0885 , 1923, A section through the New Albany Shale: Tndfana Department: of Conservation 1th Annual Report, $\mathrm{p}, 18-21$,

0886 Reger, D. B., 1928, The Tygart Valley Devonian trees of West Virginia: American Journal of Science, 5 th series, v. 15, p. 49-57.

0887 Rexroad, C. B., 1969, Conodonts from the Jacobs Chapel Bed (Mississippian) of the New Albany Shale in southern Indiana: Indiana Geological Survey Bulletin 41, $55 \mathrm{pp}$.

0888 Rexroad, C. B., and Scott, A. J., 1964, Conodont zones in the Rockford Limestone and the lower part of the New Providence Shale (Mississippian) in Indiana: Indiana Geological Survey Bulletin 30, $54 \mathrm{pp}$.

0889 Rhoads, D. C., and Morse, J. W., 1971, Evolutionary and ecologic significance of oxygen-deficient marine basins: Lethaia, v. 4, p. 413-428.

0890 Rhodes, F. H. T., and Bloxam, T. W., 1971, Phosphatic organisms in the Paleozoic and their evolutionary significance: in Yochelson, E. L. (ed.), Proceedings of the North American Paleontological Convention: Lawrence, Kansas, Allen Press, Inc., p. 1485-1513. 
0891 Rice, C. L., and Wolcott, D. E., 1973, Geologic map of the Whitesburg quadrangle, Kentucky-Virginia, and part of the Flat Gap quadrangle, Letcher County, Kentucky: U.S. Geological Survey Geologic Quadrangle Map GQ-1119.

0892 Rich, J. L., 1948, Probable deep-water origin of the MarcellusOhio-New Albany-Chattanooga black shales (abstr.): Geolog-ical Society of America Bulletin, v. 59, p. 1346-1347.

0893 , 1951, Probable fondo origin of Marcellus-Ohio-New AlbanyChat tanooga bituminous shales: American Association of Petroleum Geologists Bulletin, v. 35, p. 2017-2040.

0894 Richards, F. A., and Vaccaro, R. F., 1976, The Cariaco Trench, an anaerobic basin in the Caribbean Sea: Deep-Sea Research, v. 3, p. 214-228.

0895 Richards, H. G., 1953, Record of the rocks, the geological story of eastern North America: New York, Ronald Press Co., 413 pp.

0896

0897

Richardson, J. B., 1969, Devonian spores: in Tschudy, R. H., and Scott, R. A. (eds.), Aspects of Pal ynology: New York, Wiley-Interscience, p. 193-222.

Ringueberg, E. N. S., 1884, A new Dinichthys from the Portage Group of western New York: American Journal of Science, $3 d$ series, v. 27 , p. 476-478.

0898 Riede1, W. R., and Foreman, H. P., 1961, Type specimens of North American Paleozoic radiolarias: Journal of Paleontology, v. 35, p. 628-632.

0899 Roe, L. M., II, 1976, Sedimentary environments of the Java Group (Upper Devonian); a three-dimensional study (abstr.): Dissertation Abstracts International, v. 37, p. $129 \mathrm{~B}$.

0900 Roen, J. B., Miller, R. L., and Huddle, J. W., 1964, The Chattanooga Shale (Devonian and Mississippian) in the vicinity of Big Stone Gap, Virginia: U.S. Geological Survey Professional Paper 501-B, p. 43-48.

0901 Rogers, A. F., 1924, Mineralogy and petrography of fossil bone: Geological Society of America Bulletin, v. 35, p. 535-556.

0902 Rolfe, W. D. I., 1962, A new phyllocarid crustacean from the Upper Devonian of Ohio: Breviora, no. 151, $7 \mathrm{pp}$.

0903 Rolfe, W. D. I., and Edwards, V. A., 1979, Devonian Arthropoda (Trilobita and Ostracoda excluded): in House, M. R., Scrutton, C. T., and Bassett, M. G. (eds.), The Devonian System, Special Papers in Palaeontology, no. 23, p. 325-329.

0904 Romenger, C., 1876a, B1ack shales of Ohio - Genesee shales of New York: Michigan Geological Survey, v. 3, part 1, p. 6568.

0905 , 1876b, Black shales of Michigan: Geological Survey of Michigan, v. 3, part 2, p. 63-67.

0906 Romer, A. S., 1933, Sharklike fishes - development of jaws and 1imbs: Man and the Vertebrates: 1, Baltimore, Penguin Books, p. 22-35.

0907 1 1946, Vertebrate Paleontology: Chicago, University of Chicago Press, p. 38-66.

0908 _ 1949, Time series and trends in animal evolution: in Jepsen, G. L., Mayr, Ernst, and Simpson, G. G. (eds.), Genetics, paleontology, and evolution: Princeton, Princeton University Press, p. 103-120. 
Rowley, R. R., 1895, Description of a new genus and five new species of fossils from the Devonian and Subcarboniferous rocks of Missouri: American Geologist, v. 16, p. 217-223. , 1900, Description of new species of fossils from the Devonian and Subcarboniferous rocks of Missouri: American Geologist, v. 25, p. 261-273.

0911 Rubarts; W. E., 1959, The Boyle-Duffin-New Albany relationships in northern Casey and western Lincoln Counties: Unpublished Masters thesis, University of Kentucky, Lexington, $53 \mathrm{pp}$.

0912 Rudwick, M. J. S., 1965, Ecology and paleoecology: in Treatise on Invertebrate Paleontology, Part H, Brachiopoda: Boulder, Geological Society of America, v. 1, p. H199-H214. , 1970, Living and Fossil Brachiopods: London, Hutchinson, 199 pp.*

0914 Ruedemann, R., 1916, Spathiocaris and Discinocarina: New York State Museum Bulletin 189, p. 98-102.

0915 , 1933, Paleozoic planktonic faunas of North America: National Academy of Science, Proceedings, v. 19, p. 157-159.

0916

0917

0918

0919

0920 , 1934, Paleozoic plankton of North America: Geological Society of America Memoir 2, p. 33-34, 41, 56-61. , 1935, Ecology of black mud shales of eastern New York: Journal of Paleontology, v. 9, p. 79-91.

Ruedemann, R., and Lochnan, Christina, 1942, Grapluliles from the Englewood Formation (Mississippian) of the Black Hills, South Dakota: Journal of Paleontology, v. 16, p. 657-659.

Ryan, W. B. F., and Cita, M. B., 1977, Ignorance concerning episodes of ocean-wide stagnation: Marine Geology, v. 23, p. 197-215.

Sannemann, D., 1955, Beitray zur Untergliederung des Oberdevons rach Cunulointen: Neues Jalirbuch fur Geologie und Palkontologie, Abhandlungen, v. 100, p. 324-331.

0921 Sartender, P., 1961, Redescription of Leiorhynchus quadracostatus: Journal of Paleontology, v. 35, p. 963-976.

0922 Sandberg, C. A., and Mape1, W. J., 1967, Devonian of the northern Rocky Mountains and plains: in Oswa1d, D. H. (ed.), International Sympocium on the Devonian System, 1967 Proceedings, Calgary, Alberta, Alberta Society of Petroleum Geologists, v. 1 , p. 843-877.

0923 Sandberg, C. A., and Ziegler, W., 1979, Taxonomy and biofacies of important conodonts of Late Devonian styriacus-Zone, United States and Germany: Geologica et Palaeontologica, v. 13, p. $173-212$.

0924 Savage, T. E., 1913, Some interesting new species of arthropods from Devonian strata of Jllinois: American Journal of Science, 4 th series, v. 35, p. 149-152.

0925 , 1920, The Devonian formations of Illinois: American Journal of Science, 4 th series, v. 49, p. 169-182.

0926 _ 1929, Tu11y fauna at the base of the black shale in eastcentral Kentucky (abstr.): Geological Society of America Bulletin, v. 1, p. 112, 249.

0927 , 1930, Devonian rock of Kentucky: Kentucky Geological Survey, series 6, v. 33, p. 14-163. 
Savage, T. E., 1931, The Devonian fauna of Kentucky: in The Paleontology of Kentucky, Kentucky Geological Survey, series 6, v. 36, p. 218 .

0929 Savage, T. E., and Sutton, A. H., 1931, Age of the black shale in south-central Kentucky: American Journal of Science, 5th series, v. 22 , p. 441-448.

0930 Schaeffer, G. C., 1850, Fossil coniferous wood from the Lower Devonian strata, Marion County, Kentucky: Proceedings of the American Association for the Advancement of Science, 4 th New Haven Meeting, p. $193-194$.

0931 Scheckler, S. E., and Banks, H. P., 1971, Anatomy and relationships of some Devonian progymnosperms from New York: American Journal of Botany, v. 58, p. 737-751.

0932 Scheele, W. E., 1965, Part 1, I-71 fossil dig: Explorer, v. 7, no. 3, p. $5-8 . *$

0933 Scheele, W. E., and Hlavin, William, 1965, I-71 Fossil dig - Part 1 , some comments on the dig: Explorer, v. 7, no. 5, p. 4-11.*

0934 Schindewolf, 0. H., 1959, Adolescent cephalopods from the Exshaw Formation of Alberta: Journal of Paleontology, v. 33, p. 971976.

0935 Schmid, Rudolf, 1967, Electron microscopy of wood of Callixylon and Cordaites: American Journal of Botany, v. 54, p. 720-729.

$0936 \ldots$ _ 1976, Septal pores in Prototaxites, an enigmatic Devonian plant: Science, v. $191, \overline{\text { p. } 287-288}$.

0937 Schopf, J.M., 1953, Organic matter of the Chattanooga Shale: U.S. Atomic Energy Commission, TEI-330, p. 146-152.

$0938 \ldots$ 1957, Spores and problematic plants commonly regarded as marine - annotated bibliography: in Ladd, H. S. (ed.), Treatise on Marine Ecology and Paleoecology: Geological Society of America, Memoir 67, v. 2, p. 709-718. , 1978, Foerstia and recent interpretations of early, vascular 1 and plants: Lethaia, v. 11, p. 139-143.

0940 Schopf, J. M., and Schwietering, J. F., 1970, The Foerstia zone of the Ohio and Chattanooga shales: U.S. Geological Survey Bulletin 1294-H, 15 pp.

0941 Schopf, J. M., Wilson, L. R., and Bental1, Ray, 1944, An annotated synopsis of Paleozoic fossil spores and the definition of generic groups: Illinois State Geological Survey Report of Investigations $91,74 \mathrm{pp}$.

0942 Schopf, T. J. M., 1980, Paleoceanography: Cambridge, Harvard University Press, $341 \mathrm{pp}$.

0943 Schott, G. L., Overbey, W. K., Jr., Hunt, A. E., and Komar, C. A. (eds.), 1978, First Eastern Gas Shales Symposium, Proceedings: Morgantown, West Virginia, U.S. Department of Energy, Morgantown Energy Research Center, MERC/SP-77/5, $783 \mathrm{pp}$.

0944 Schram, F. R., Feldman, R. M., and Copeland, M. J., 1978, The Late Devonian Palaeopalaemonidae and the earliest decapod crustaceans: Journal of Paleontology, v. 52, p. 1375-1387.

0945 Schuchert, Charles, 1905, Contributions to Devonian paleontology: American Journal of Science, 4 th series, v. 19, p. 460-463. , 1910a; Paleogeography of North America: Geological Society of America Bulletin, v. 20, p. 420-606. 
0947 Schuchert, Charles, 1910b, Biologic principles of paleogeography: Popular Science Monthly, p. 560-591.*

0948 , 1915, The conditions of black shale deposition as illustrated by Kupferschiefer and Lias of Germany: American Philosophical Society Proceedings, v. 54, p. 259-269.*

$0949 \ldots$ 1927a, Winters in the Upper Devonian: American Journal of Science, 5th series, v. 13, p. 123-132.

0950

0951 1927b, Winters in the Upper Devonian: American Journal of Science, 5 th series, v. 14, p. 159.

0952 1943, Stratigraphy of the eastern and central United States: New York, John Wiley and Sons, Inc., $1013 \mathrm{pp}$.

0953

0954 1955, Atlas of paleogeographic maps of North America: New York, John Wiley and Sons, Inc., p. 34-41.

Schumacher, Dietmar, 1976, Conodont biofacies and paleoenvironments in Middle Devonian - Upper Vevonian boundary beds, central Missouri: in Barnes, L. R. (ed.), Geological Association of Canada Special Paper 15, p. 159-169.

Schwarzback, M., 1961, Paleoclimates in Europe and North America: in Nairn, A. E. M. (ed.), Descriptive Paleoclimatology, New York, Interscience, p. $261-262$.

0955 Schwietering, J. F., 1970, Devonian Shales of Ohio and their Eastern Equivalents (abstr.): Dissertation Abstracts International, v. 31, p. 2067B.

0956 , 1972, Olentangy Shale (Middle and Upper Devonian) and its equivalents in western parts of Pennsylvania and New York (abstr.): North-Central Section, 6th Annual Meeting, Geological Society of America Abstracts with Programs, v. 4, p. 350. , 1978, Preliminary model of Catskill Delta in West Virginia: in Schott, G. L., and others (eds.), First Eastern Gas Shales Symposium, Proceedings, Morgantown, West Virginia, U.S. Department of Energy, Morgantown Energy Research Center, MERC/ SP $77 / 5$, p. 195-205.

0958 Schwictcring, J.F., and Neal, D. W., I9̣78, nccurrence of Fuerstia (Protosalvinia) in I.incoln County, West Virginia: Geology, v. 6, p. 493, 494 .

0959 Scott, A. J., 1961, Three new conodonts from the Louisiana Limestone (Upper Devonian) of western Illinois: Journal of Paleontology, v. 35, p. 1223-1227.

0960 Scott, A. J., and Collinson, C., 1961, Conodont faunas from the Louisiana and McCraney formations of Illinois, Iowa, and Missouri: in Kansas Geological Society Guidebook, 26tl Annual Field Conference, p. 110-141.

0961 Scott, D. H., 1902, On the primary structure of certain Paleozoic stems with the Dadoxylon type of wood: Transactions of the Royal Society of Edinburgh, v. 40, p. 331-373.

0962 , 1915, Lepidostrobus kentuckiensis, nomen nov., formerly L. fischeri, Scott and Jeffrey: a correction: Proceedings of the Royal. Society of London, v. 88B, p. 435-436.

0963 Scott, D. H., and Jeffrey, E. C., 1914, On fossil plants showing structure from the base of the Waverly Shale of Kentucky: Philosophical Transactions of the Royal Society of London, v. 205B, p. 315-373. 
0964 Scott, H. W., 1948, Significance of crustaceans in dwarfed faunas: Journal of Sedimentary Petrology, v. 18, p. 65-70.

0965 Sebby, W. S., and Matten, L. C., 1969, Kalymma minuta (Read) comb. nov. from the New Albany Shale: Torrey Botany Club. Bulletin, v. 96, p. 79-88.

0966 Sedden, George, 1970, Frasnian conodonts from the Sadler RidgeBugle Gap area, Canning Basin, Western Australia: Journal of the Geological Society of Australia; v. 16, p. 723-753.

0967 Seddon, George, and Sweet, W. C., 1971, An ecologic model for conodonts: Journal of Paleontology, v. 45, p. 869-880.

0968 Seilacher, A., Drodzewski, G., and Haude, R., 1968, Form and function of a stem in a psuedo-planktonic crinoid (Seirocrinus): Palaeontology, v. 11, p. 275-282.

0969 Seward, A. C., 1917, Fossil plants, a textbook for students of botany and geology: Cambridge, Cambridge University Press, v. 3, p. 291-293.

0970

0971

0972

0973

0974 , 1933, The Devonian Period: in Plant Life through the ages: Cambridge, Cambridge University Press, p. 139-154.

Shaler, N. S., 1877, Notes on the investigations of the Kentucky Geological Survey: in Geological Survey of Kentucky Reports of Progress, v. 3, new series; p. 169-173.

Survey, no. 1, p. 5-12.

Sharpe, Charles, and others, 1976, Economic potential of the Ohio black shales in northeastern Kentucky: NSF-SOS Grant no. 76-08113, p. 22-23.

Sheldon, R. P., 1964, Paleolatitudinal and paleogeographic distribution of phosphorite: U.S. Geological Survey Professional Paper 501-C, p. C106-C113.

0975 Shepps, V. C. (ed.), 1963, Symposium on Middle and Upper Devonian Stratigraphy of Pennsylvania and Adjacent States: Pennsylvania Geological Survey, 4th series, General Geological Report 39, $301 \mathrm{pp}$.

0976

Shimer, H. W., 1908, Dwarf-faunas: American Naturalist, v. 42, p. $472-490$.

0977 Smith, Burnett, 1909, On some Dinichthyid armor plates from the Marcellus Shale: American Naturalist, v. 43, p. 588-597.

0978 , 1910, Notes on some little-known fishes from the New York Devonian: Academy of Natural Science of Philadelphia Proceedings, V. 62, p. 656-663.

0979 Smith, G. A., Briden, J. C., and Drewery, G. E., 1973, Phanerozoic world maps: in Hughes, N. V. (ed.), Organisms and Continents through Time: Special Papers in Palaeontology, no. 12 , p. 1-42.

0980 Smith, G. 0., and White, David, 1905, Geology of the Perry basin in southeastern Maine: U.S. Geological Survey Professional Paper 35, p. 35-84.

0981 Smith, J. P., 1903, The Carboniferous ammonoids of America: U.S. Geological Survey Monograph 42, 211 pp.

0982 Sohn, I. G., 1960, Paleozoic species of Bairdia and related genera: U.S. Geological Survey Professional Paper 330-A, $115 \mathrm{pp}$. 
0983 Sohn, I. G., 1961, Aechmine11a, Amphissites, Kirkbyella, and related genera: U.S. Geological Survey. Professional Paper $330-\mathrm{B}, 160 \mathrm{pp}$.

0984 Sommer, F. W., 1951, 0 problema de Protosalvinia brazilensis. Dawson: Academy Brasileira, cien anais, v. 23, p. 415-419.

0985 Stach, E., and others, 1975, Coal Petrology: Berlin, Gegruder Borntraeger, p. 212 .

0986 Stainbrook, M. A., 1935, A Devonian fauna from the Sacramento Mountains near Alamogordo, New Mexico: Journal of Paleontology, v. 9, p. 709-714.

0987 , 1947, Brachiopoda of the Percha Shale of New Mexico and Arizona: Journal of Paleontology, v. 21, p. 297-328.

0988 Stanley, S. M., 1970, Relation of shell form to life habits of the Bivalvia (Mollusca): Geological Society of America Memoir 125, $296 \mathrm{pp}$.

0989 Stanton, R. J., 1963, Upper Devonian calcispheres from Redwater and South Sturgeon Lake reefs, Alberta, Canada: Canadian Petroleum and Economics Bulletin, v. 11, p. 410-418.

0990

Staplin, F. L., 1961, Reef-controlled distribution of Devonian microplankton in Alberta: Palaeontology, v. 4, p. 392-424.

0991

Stauffer, C. R., 1908, The Devonian section on Ten Mile Creek, Lucas County, Ohio: Ohio Naturalist, v. 8, p. 271-276.

$0992 \ldots$ _ 1915a, The Devonian of southwestern Ontario: Geological Survey of Canada Memoir 34, 341 pp.

0993 , 1915b, Olentangy Shale and associated deposits of northern Ohio (abstr.): Geological Society of America Bulletin, v. 26, p. 95-96.

0994 , 1916, The relationship of the 0lentangy Shale and associated Devonian deposits of northern Ohio: Journal of Geology, v. 24, p. $476-487$.

0995 , 1918, Descriptions of some new species of Devonian fossils: Inurnal of Geology, v. 26, p. 555-560.

0996

0997 , 1938a, Conodonts of the Olentangy Shale: Journal of Paleontningy, v. 12, p. 411-443.

0998

0999

1000 , 1938b, The fauna of the typical 0lentangy Shale: Journal of Geology, v. 46, p. 1075-1078. , 1940, Conodonts from the Devonian and associated clays of Minnesota: Journal of Paleontology, v. 14, p. 417-435.

S.tauffer, C. R., Hubbard, G. D., and Bownocker, J. A., 1911, Geology of the Columbus quadrangle: Ohio Geological Survey Bul1etin 14, .. 25-34, 50 .

Stearn, C. C., Carrol1, R. L., and Clark, T. H., 1979, Geological evulution of North America, 3d edition: New York, John Wiley and Sons; $566 \mathrm{pp}$.

1001 Steele-Petrovic, H. M., and Thayer, C. W., 1971, Burrowing of the lingulid brachiopod Glottidia pyrimidata (abstr.): Geological Society of America Abstracts with Programs, v. 3, p. 719.

1002 Stensio, E. A., 1925, On the head of Macropetalichthyids, with certain remarks on the head of other Arthrodires: Field Museum Publication, v. 232, p. 89-197.

1003 , 1937, Notes on the endocranium of a Devonian Cladodus: Upsala Bulletin of Geology, v. 27, p. 128-144. 
1004 Stensio, E. A., 1968, The spinal plate in Homostius and Dunkleosteus - Discussion: in Orvik, Tor (ed.), Current

$\overline{\text { Problems }}$ of Lower Vertebrate Phylogeny, 4 th Nobel Symposium, Stockholm, 1967 Proceedings, New. York, Interscience, p. 148151.

1005 Stetson, H. C., 1930, Notes on the structure of Dinichthys and Macropetalichthys: Bulletin of the Harvard Museum of Comparative Zoology, v. 71, p. 19-39.* *

1006 Stevenson, J. J., 1878, The Upper Devonian rocks southwest Pennsylvania: American Journal of Science, 3d. series, v. 15, p. 423-430.

1007 _ 1892, The Chemung and Catskill (Upper Devonian) on the eastern side of the Appalachian basin: Proceedings of the American Association for the Advancement of Science, v. 40, p. 219247; American Geologist, v. 9, p. 6-33.

1008 Stewart, G. A., 1944, Ostracoda from Middle Devonian bone beds in central Ohio: Journal of Paleontology, v. 24, p. 652-666.

1009 Stewart, G. A., and Hendrix, W. E., 1939, Ostracodes as a possible aid in the Olentangy Shale problem (abstr.): Geological Society of America Bulletin, v. 50, p. 1988, 1989.

1010 , 1945a, Ostracoda of the Plum Brook Shale, Erie County, Ohio: Journal of Paleontology, v. 19, p. 87-95.

1011 , 1945b, Ostracoda of the Olentangy Shale, Franklin and Delaware County, Ohio: Journal of Paleontology, v. 19, p. 96115.

1012 Stewart, G. A., and Lampe, Lois, 1947, Foraminifera from the Middle Devonian bone beds of Ohio: Journal of Paleontology, v. 21, p. $529-536$.

1013 Stockdale, P. B., 1939, Lower Mississippian rocks of the eastcentral Interior: Geological Society of America Special Paper 22 , p. $50,75,87-91$.

1014 Stose, G. W., 1923, Pre-Pennsylvanian rocks: in Eby, J. B. (ed.), The geology and mineral resources of Wise County and the coalbearing portion of Scott County, Virginia: Virginia Geological Survey Bulletin 24, p. 22-62.

1015 Stose, G. W., and Swartz, C. K., 1912, Pawpaw-Hancock Folio, Maryland-West Virginia-Pennsylvania: U.S. Geological Survey Geologic Atlas of the United States Folio 179, 24 pp.

1016 Straka, J. J., 1968, Conodont zonation of the Kinderhookian Series, Washington County, Iowa: Iowa University Studies in Natural History, v. 21, p. 1-71.*

1017 Stumm, E. C., Kellum, L. B., and Wright, J. D., 1956, Devonian strata of the London-Sarnia area, southwestern Ontario, Canada: Field Trip, Michigan Geological Society, Michigan Geological Survey, $21 \mathrm{pp}$ **

1018 Sturgeon, M. C., Hlavin, W. J., and Kesling, R. V., 1964, Rare crustaceans from the Upper Devonian Chagrin Shale in northern Ohio: University of Michigan Museum Paleontology Contributions, v. 19, p. 47-64.

1019 Sutton, A. H., 1944, The Devonian System in Indiana: in Illinois State Geological Survey Bulletin 68, p. 162-173. 
1020 Sutton, R. G., Bowen, Z. P., and McAlester, A. L., 1970, Marine shelf environments of the Upper Devonian Sonyea Group of New York: Geological Society of America Bulletin, v. 81, p. 2975-2992.

1021. Swager, D. R., 1978, Stratigraphy of the Upper Devonian-Lower Mississippian Shale Sequence in the Eastern Kentucky Outcrop Be1ts: Unpublished Masters thesis, University of Kentucky, Lexington, $116 \mathrm{pp}$.

1022 Swager, D. R., and Ettensohn, F. R., 1978, The stratigraphy of Mississippian black shales along the east-central Kentucky outcrop belt (abstr.): Geological Society of America Abstracts with Programs, v. 10, p. 199.

1023 Swain, F. M. (ed.), 1977a, Stratigraphic micropaleontology of Atlantic Basin and borderlands: Developments in Palaeontology and Stratigraphy, no. 6, New York, Elsevier, $603 \mathrm{pp}$. - 1977b, Notes on Paleozoic acritarchs from the Atlantic margin: in Swain, F. M. (ed.), Stratigraphic Micropaleontology of Atlantic Basin and borderlands: Developments in Palaeontology and Stratigraphy, no. 6, New York, Elsevier, p. 137-150.

1025 _ 1978, Organic materials of early Middle Devonian, Mt. Union area, Pennsylvania: American Association of Petroleum Geologists Bulletin, v. 42, p. 2858-2891.

1026 Swanson, V. E., 1960, 0il yield and uranium content of black shalcs: U.S. Geological Survey Professional Paper 356-A, p. $1-44$.

1027 _ 1961, Geology and geochemistry of uranium in marine black shales - a review: U.S. Geological Survey Professional Paper 356-C, p. 67-112.

1028 Swanson, V. E., and Landis, E. R., 1962, Geology of a uraniumbearing black shale of Late Devonian age in north-central $\Lambda$ rkansas: Arkansas Geology and Conservation Commission Information Circular 22, $16 \mathrm{pp}$.

1029 Swartz, C. K., 1908, The succession of faunas in the Portage and Chemung formations of Maryland: Journa1 of Geology, v. 16, p. 328-346.

$1030 \quad$ 1910, Recurrence of Tropidoleptus fauna in the Chemung of Maryland: Geological Society of America Bulletin, v. 20, 679-686.

1031 , 1913a, Systematic paleontology of the Upper Devonian deposits of Maryland; vertebrata: Maryland Geological Sur.vey, Middle and Upper Devonian, v. 6, p. 700-701.

$1032 \ldots$, 1913h, Correlation of the Upper Devonian; Local sections of the Upper Devonian (of Maryland): Maryland Genlogi.ral Survey, Middle and Upper Devonian, v. 6, p. 410-534.

1033 Swartz, F. M., 1930, The Helderberg Croup of parts of West Virginia and Virginia: U.S. Geological Survey Professional Paper 158-C, p. 27-75.

1034 Swartz, J. H., 1923, The age and stratigraphy of the Chattanooga Shale in northeastern Tennessee and in Virginia: American Journal of Science, 5th series; v. 17, p. 431-438. , 1924, The age of the Chattanooga Shale of Tennessee: American Journal of Science, 5 th series, v. 7, p. 24-30. 
1036 Swartz, J. H., 1927, Chattanoogan age of the Big Stone Gap Shale: American Journal of Science, 5 th series, v. 14, p. 485-499.

1037 1929a, The age and stratigraphy of the Chattanoogan shale in northeastern Tennessee and Virginia: American Journal of Science, 5th series, v. 17, p. 431-448.

1038 , 1929b, The Devonian-Mississippian boundary in southeast United States: Science, v. 70, p. 609.

1039 Sweet, W. C., and Bergstrom, S. M., 1970-1971, Symposium on conodont biostratigraphy: Geological Society of America Memoir 127, 499 pp.

1040 Szmuc, E. J., 1970, The Devonian System: in Guide to the Geology of Northeastern Ohio, Northern Ohio Geological Society, Kent, p. $9-20$.*

1041 Szmuc, E. J., Osgood, R. G., Jr., and Meinke, D. W., 1976, Lingulichnites, a new trace fossil genus for lingulid brachiopod burrows: Lethaia, v. 9, p. 163-167.

1042 Tarr, W. A., 1927, Alternating deposition of pyrite, marcasite and possibly melnikovite: American Mineralogist, v. 12, p. 417-421.

1043 Tasch, Paul, 1967, The problem of primary production in the seas through geologic time: Review of Palaeobotany, v. 1, p. 283290.

1044 Teichert, Curt, and Yochelson, E. L. (eds.), 1967, Essays in Paleontology and Stratigraphy, R. C. Moore Commemorative Volume: Department of Geology, University of Kansas, Special Publication 2, Lawrence, University of Kansas Press, $626 \mathrm{pp}$.

1045 Tesmer, I. H., 1955, Restudy of Upper Devonian (Chautauquan) stratigraphy and paleontology in southwestern New York State: New York Museum Circular 42, 22 pp.

1046 , 1963, Geology of Chautauqua County, New York - Part 1, stratigraphy and paleontology (Upper Devonian): New York State Museum and Science Service Bulletin 391, 65 pp.

$1047 \ldots$ _ 1968, Upper Devonian stratigraphy and paleontology of southwestern New York State: in Oswald, D. H. (ed.), International Symposium on the Devonian System, 1967 Proceedings, Calgary, Alberta, Alberta Society of Petrology Geologists, v. 2, p. 259-269.

1048 Thayer, C. W., 1974, Marine paleoecology in the Upper Devonian of New York: Lethaia, v. 7, p. 121-155.

1049 Thayer, C. W., and Steele-Petrovic, H. M., 1975, Burrowing of the lingulid brachiopod Glottidia pyrimidata: its ecologic and paleoecologic significance: Lethaia, v. 8, p. 209-221.

1050 Theede, H., Ponat, A., Hiroki, K., and Schlieper, C., 1969, Studies on the resistance of marine bottom invertebrates to oxygen defiriency and hydrogen sulfide: Marine Biology, v. 2, p. 325337.

1051 Thiessen, R., 197.1, Origin and composition of certain oil shales: Economic Geology, v. 16, p. 289-300.

1052 _._1925, Microscopic examination of Kentucky oil shales: in Thiessen, R., White, D., and Crouse, C. S., Oil shales of Kentucky: Kentucky Geological Survey, series 6, v. 21, p. 147. 
1053 Thomas, A. O., 1931, Late Devonian foraminifera from Iowa: Journal of Paleontology, v. 5, p. 40, 41.

1054 Thomas, L. A., 1949, Devonian-Mississippian formations of southeast Iowa: Geological Society of America Bulletin, v. 60, p. 403-438.

1055 Thomson, K. S., 1975, The biology of cosmine: Yale University Peabody Museum of Natural History Bulletin, v. 40, p. 1-57.

$1056 \ldots$ _ 1976, The faunal relationships of rhipidistian fishes (Crossopterygii) from the Catskill (Upper Devonian) of Pennsylvania: Journal of Paleontology, v. 50, p. 1203-1208.

1057 Thompson, T. L., and Fellows, L. D., 1970, Stratigraphy and conodont biostratigraphy of Kinderhookian and Osagian (Lower Mississippian) rocks of southwestern Missouri and the adjacent area: Missouri Division of Geological Survey and Water Resources Report of Investigations 45, 263 pp.

1058 Thorson, G., 1961, Length of pelagic larval life in marinc bottom invertebrates as related to larval transport by ocean currents: in Sears, M. (ed.), Oceanography, American Association for the Advancement of Science.

1059 Tillman, J. R., 1969, On the age of the 0lentangy Shale of central Ohio (abstr.): Geological Society of America Abstracts with Programs, v. 1, p. 49 .

$1060 \ldots$ _ 1970, The age, stratigraphic relationships, and correlation of the lower part of the 0lentangy Shale of central Ohio: Ohio Journal of Science, v. 70, p. 202-217.

1061 Toomey, D. F., Mamet, B. L., 1979, Devonian protozoa: in House, M. R., Scrutton, C. T., and Bassett, M. G. (eds.), The Devonian System: Special Papers in Palaeontology, no. 23, p. 189192.

1062 Traquair, R. H., 1890, Notes on the Devonian flshes of Scaumenac Bay and Campbelltown in Canada: Geological Magazine, new Series, v. 7, p. 15-22.

1063 _ 1893, Notes on the Devonian fishes of Campbelltown and Scaumenac Bay in Canada; Royal Physical Society of Edinhurgh Proceedings, v. 12, p. 111-125.*

1064 Triplett, J. C., and Trumbo, D. B., 1975, Bibliography of Upper Devonian shale sequence: U.S. Department of Energy, Eastern Gas Shales Project, Open File Report 006, 78. pp.

1065 Tschudy, R. H., and Scott, R. A. (eds.), 1969, Aspects of Palynology: An Introduction to Plant Microfossils in Time: New York, Wiley-Intersienie, $510 \mathrm{pp}$.

1066 Twenhofel, W. H., 1915, Notes on black shale in the making: American Journal of Science, 4 th series, v. 40, p. 272-280.

1067 1926, Treatise on Sedimentation: Baltimore, The Williams and Wilkins Co., $661 \mathrm{pp}$.

$1068 \ldots$ _ 1931, The building of Kentucky: Kentucky Geological Survey, series $6, v .37$, p. 1-230.

1069 _ 1939, Environments of origin of black shales: American Association of Petroleum Geologists Bulletin, v. 23, p. 11781198 . 
1070 Udden, A. D., 1897, A brief description of the section of Devonian rocks exposed in the vicinity of Rock Island, I11., with a statement of the nature of its fish remains: Cincinnati Society of Natural History Journal, v. 19, p. 93-95.

107.1 Ulrich, E. 0., 1911, Revision of the Paleozoic systems: Geological Society of America Bulletin, v. 22, p. 625-668.

1072 , 1912, The Chattanooga Series with special reference to the Ohio Shale problem: American Journal of Science, 4 th series, v. 34, p. 157-183.

1073 , 1915, The Kinderhookian age of the Chattanooga Series (abstr.): Geological Society of America Bulletin, v. 26, p. 96-99.

1074 U:1rich, E. 0., and Bassler, R. S., 1926, A classification of the toothlike fossils, conodonts, with descriptions of American Devonian and Mississippian species: U.S. National Museum Proceedings, v. 68, p. 1-63.

1075 Ulrich, E. 0., Clarke, J. M., Scofield, W. H., and Winche11, N. H., 1897, Paleontology: Geology of Minnesota, Minnesota Geological and Natural History Survey, v. 3, part 2, p. cv.

1076 Uyeno, T. T., 1967, Conodont zonation, Waterways Formation (Upper Devonian) northeastern and central Alberta: Geological Survey of Canada Paper 67-36, p. 1-21.

1077 Van Horn, F. R., and Van Horn, K. R., 1933, X-ray study of pyrite or marcasite concretions in the rocks of the Cleveland, Ohio quadrangle: American Mineralogist, v. 18, p. 288-294.

1078 Verwiebe, W. A., 1916, The Berea Formation of Ohio and Pennsy1vania: American Journal of Science, 4 th series, v. 42, p. 43-58.

1079 _ 1917, Correlation of the Devonian Shales of Ohio and Pennsylvania: American Journal of Science, 4 th series, v. 44, p. 33-47.

1080 Von Zittel, K. A., 1937, Pisces: in Textbook of paleontology: London, MacMillan \& Co. Ltd., v. 2, $464 \mathrm{pp}$.

1081 Wall, D., 1962, Evidence from recent plankton regarding the biological affinities of Tasmanites Newton 1875 and Leosphaeridia Eisenack 1958: Geological Magazine, v. 99, p. 353-362.

1082 Walls, R. A., 1972, Sedimentology, paleontology, and paleogeography of Upper Devonian-Lower Mississippian silt and shale facies in southeastern Appalachian basin: Geological Society of America Abstracts with Programs, v. 4, p. 111 .

1083 , 1973, Late Devonian-Early Mississippian subaqueous deltaic facies in a portion of the southeastern Appalachian basin: in Chuber, Stewart (ed.), Gulf Coast Association of Geological Societies Transactions, v. 24, p. 41-45.

1084 Ward, L. F., 1889, The geographical distribution of fossil plants: U.S. Geological Survey 8th Annual Report, part 2, p. 884-941.

1085 Warren, P. S., 1937, Age of the Exshaw Shale in the Canadian Rockies: American Journal of Science, 5th series, v. 33, p. 454457.

1086 , 1956, The Exshaw Shale: Alberta Society of Petroleum Geologists Journa1, v. 4, p. 141-142. 
1087 Warshauer, S. M., 1978, Ostracode biostratigraphy in the bottom 395 feet of CGTC Well 20403, Lincoln County, W. VA.: Eastern Gas Shales Project, Open File Report 109, 12 pp.

1088 Warthin, A. S., Jr., 1934, Common ostracoda from the Traverse Group: University of Michigan Museum Paleontology Contributions, v. 4, p. 205-226.

1089 Watt, A. D., 1970, Catalog of the illustrated Paleozoic plant specimens in the National Museum of Natural History: Smithsonian Contributions to Paleobiology, no. 5, $53 \mathrm{pp}$.

1090 Weddige, Karsten, and Ziegler, Willi, 1976, The significance of Icriodus: Polygnathus ratios in limestones from the type Eifelian, Germany: in Barnes, C. R. (ed.), Conodont Paleoecology, Geological Association of Canada Special Paper 15, p. 187-199.

1091 _ 1979, Evolutionary patterns in Middle Devonian conodont genera Polygnathus and Icriodus: Geologica et Palaeontologica, v. 13, p. 157-164.

1092 Weir, G. W., 1967, Geologic map of the Berea quadrangle, eastcentral Kentucky: U.S. Geological Survey Geologic Quadrangle Map GQ-649.

1093 Weir, G.: W., Lee, K. Y., and Cassity, Y. E., 1971, Geologic map of the Bighill quadrangle east-central Kentucky: U.S. Geological Survey Geologic Quadrangle Map GQ-900.

1094 Weller, J. M., 1944, Devonian System in southern I11inois: in I1linois State Geological Survey Bulletin 68, p. 89-102.

1095 Weller, J. M., and Sutton, A. H., 1940a, Mississippian border of eastern interior basin: American Association of Petroleum Geologists Bulletin, v. 24, p. 765-858.

1096 _ 1940b, Mississippian border of eastern interior basin: llinois State Geological Survey Report of Investigations 62, p. 765-858.

1097 Weller, Stuart, 1895, A circum-insular Paleozoic fauna: Journal of Geology, v. 3, p. 203-917.

1098 _ 1897, Conrrolntinn of the Devonian Caunde in buulhum Illinois: Journal of Geology, v. 5, p. 625-635.

$1099 \ldots$ _ 1899, A peculiar Devonian deposit in northeastern Illinois: Journal of Geology, v. 7, p. 483-488.

1100 , 1909, Correlation of the Middle and Upper Devonian and the Mississippian faunas of North America: Journal of Geology, v. 17, p. 257-285.

$1101 \ldots$ _ 1914, 'l'he Mississippian brachiopods of the Mississippi Valley basin: Illinois State Geological. Survey Monograph 1, text and plates, $508 \mathrm{pp}$.

1.02 , 1920, Geology of Hardin County: Illino1s Etate Geological. Survey Bulletin, v. 41, p. 89.

1103 We1ls, J.W., 1939, Association of crinoids with Callixylon in the lower Ohio Shale: Paleobiologica, v. 7, p. 105-110.*

$1104 \ldots$ 1941, Crinoids and Callixylon: American Journal of Science, v. 239 , p. 454-456.

1105 _ 1944, Middle Devonian bone beds of Ohio: Geological Society of America Bulletin, v. 55, p. 273-302. 
1106 Wells, J. W., 1947, Provisional paleoecological analysis of the Devonian rocks of the Columbus region: Ohio Journal of Science, v. 47, p. 119-126.

1107 Westgate, L. G., 1926, Geology of Delaware County: Ohio Geological Survey, 4th series, Bulletin 30, p. 37-39, 42-43.

1108 Westol1, T. S., 1943, The origin of the tetrapods: Biological Review, v. 18, p. 78-98.

$1109 \ldots$ _. 1979, Devonian fish biostratigraphy: in House, M.! R., Scrutton, C. T., and Bassett, M. G. (eds.), The Devonian System: Special Papers in Palaeontology, no. 23, p. 341-353.

1110 Wethered, E., 1886, On the occurrence of spores of plants in the lower limestone shales of the Forest of Dean Coalfield and in the black shales of Ohio, United States: Proceedings of the Cotteswold Nature Field Club, v. 8, p. 167-173.*

1111 White, C. A., 1883, On the Macrocheilus of Phillips, Plectostylus of Conrad, and Joleniscus of Meek and Worthen: U.S. National Museum Proceedings, v. 6, p. 184-187.*.

1112 White, C. D., 1902, Fossil alga from the Chemung of New. York, wi.thremarks on the genus Haliserites Sternberg: New York State

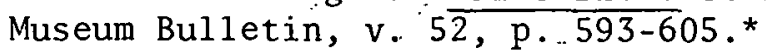

1113 , 1907a, A remarkable fossil tree trunk from the Middle Devonic of New York: New York State Museum Bulletin, v. 107, p. 327360 *

$1114 \ldots$ 1907b, A composite lycopod type from the Devonian (abstr.): Science, new series, v. 25 , p. $269 . *$

$1115 \ldots$ _ 1909, The Upper Paleozoic flora: Journal of Geology, v. 17, p. $320-341$.

1116 _ 1911, Value of floral evidence in marine strata as indicative of nearness of shores: in Conference on Faunal Criteria in Paleozoic Paleogeography: Geological Society of America Bulletin, v. 22, p. 221-227.

1117 White, C. D., and Knowlton, F. H., 1910, Evidences of paleobotany as to geological climate (abstr.): Science, new series, v. 31, p. $760 . *$

1118 White, C. D., and Stadnichenko, T., 1923, Some mother plants of petroleum in the Devonian black shales: Economic Geology, v. 18, p. $238-252$.

1119 White, I. C., 1881, The geology of Erie and Crawford Counties: Pennsylvania Geological Survey, 2d, Q4, 406 pp.

1120 Whiteaves, J. F., 1880a, New species of Pterichthys, allied to Bothriolepis ornata: American Journal of Science, $3 \mathrm{~d}$ series, v. 20, p. $132-136$.

1121 , 1880b, Some new and remarkable fossil fishes from the Devonian rocks of the northern side of the Baie des Chaleurs (abstr.): Canadian Naturalist and Geologist and Proceedings of the Natural History Society of Montrea1, v. 9, p. 315.* , 1881a, On some remarkable fossil fishes from the Devonian rocks of Scaumenac Bay, P. Q. with descriptions of a new genus and three new species: Canadian Naturalist, new series, v. 10, p. $27-35$.* 
1123 Whiteaves, J. F., 1881b, On some fossil fishes, Crustacea, and Mollusca from the Devonian rocks at Campbelltown, N. B., with descriptions of five new species: Canadian Naturalist and Geologist and Proceedings of the Natural History Society of Montreal, v. 10, p. 93-101.*

1124 , 1883, Recent discoveries of fossil fishes in the Devonian rocks of Canada: American Naturalist, v. 17, p. 158-164; Proceedings of the American Association for the Advancement of Science, v. 31, p. 353-356.*

1125 , 1886, Illustrations of the fossil fishes of Canada: Transactions of the Royal Society of Canada, v. 4, section 4,

1126 p. 101-110. , 1889, Illustrations of the fossil fishes of the Devonian rocks of Canada, Part II: Transactions of the Royal Society of Canada, v. 6, section 4, p. 77-96.

1
, 1899, The Devonian System in Canada: American Association for the Advancement of Science, the A p. 193-223; American Geologist, v. 24, p: 210-240; Science, new series, v. 10, p. 402-412,430-438; (abstr.):, Canadian Record of Science, v. 8, p. 195-198.

1128 , 1908, Illustrations of the fossil fishes of the Devonian rocks of Canada: Transactions of the Royal Society of Canada, series 3, v. 1, section 4, p. 245-274.

1129 Whitfield, R. P., 1875, Fossils from the black slate formations of southern Indiana and adjacent portions of Kentucky: Indiana Geological Survey, 6th Annual Report, p. 179-182.

$1130 \quad 1880 \mathrm{a}$, Notice of new forms of fossil crustaceans from the Upper Devonian rocks of Ohio, with descriptions of ncw genera and species: American Journal of Science, $3 \mathrm{~d}$ series, v. 19, p. 33-42.

1131 , 1880b., Notice of the occurrence of rocks representing the Marcellus Shale of New York, in central Ohio: Proceedings of the American $\Lambda$ ssociation for the $\Lambda$ dvancement of Science, v. $28, p, 297-299, *$

$1132 \ldots$, 1889, Description of a new form of fossil balanoid cirripeda from the Marcellus Shale of New York: American Museum of Natural History Bulletin, v. 2, p. 66-68.*

1133 _. 1892, Discovery of a second example of the macrouran decapod crustacean Palaeopalaeomon newberryi: American Geologist, v. 9, p. $237-238$.

$1134 \ldots$ 1895, Contriburions to the páléontólogy of Uhio: in Urton, E., economic geology, archaeology, botany, paleontology: Ohio Geological Survey Reports, v. VII, p. 407-494.

1135 Whittlesey, Charles, 1851, On the equivalency of the rocks of northeastern Ohio and the Portage, Chemung, and Hamilton rocks of New York: Proceedings of the American Association for the Advancement of Science, v. 5, p. 207-221.*

1136 Wicander, E. R., 1973a, Phytoplankton abundance and diversity during the Late Devonian and Early Mississippian of Ohio (Abstr.): American Association of Petroleum Geologists Bulletin, v. 57, p. 812 . 
1137 Wicander, E. R., 1973b, Marine primary productivity during the Late Devonian-Early Mississippian of Ohio (abstr.): Cordi1leran Section, 69th Annual Meeting, Geological Society of America Abstracts with Programs, v. 5, p. 121-122.

1138 , 1974, Upper Devonian-Lower Mississippian acritarchs and prasinophycean algae from Ohio, U.S.A.: Palaeontographica, Abt. B, v. 148, p. 9-43.*

$1139 \quad$, 1975, Fluctuations in a Late Devonian-Early Mississippian phytoplankton flora of Ohio, U.S.A.: Palaeogeography, Palaeoclimatology, Palaeoecology, v. 17, p. 89-108.

1140 Wicander, E. R., and Loeblich, A. R., Jr., 1977, Organic-walled microphytoplankton and its stratigraphic significance from the Upper Devonian Antrim Shale, Indiana, U.S.A.: Palaeontographica, Abt. B, v. 160, p. 129-165.*

1141 Wickwire, G. T., 1936, Crinoid stems on fossil wood: American Journal of Science, 5th series, v. 32, p. 145.146.

1142 Wigley, P. B., and Clayton, J. W., 1973, Conodont assemblages from the New Albany Shale of Kentucky (abstr.): North-Central Section, 7th Annual Meeting, Geological Society of America Abstracts with Programs, v. 5, p. 365-366.

1143 Wigley, P. B., and Sergeant, R. E., 1970, Penecontemporaneous sedimentary structures in the Ravenna facies of the New Albany Shale (abstr.): Geological Society of America Abstracts with Programs, v. 2, p. 248-249.

1144 Willard, B., 1934, Early Chemung shoreline in Pennsylvania: Geological Society of America Bulletin, v. 45, p. 897-907.

1145 Williams, A. J., 1977, Insight into lingulid evolution from the Late Devonian: Alcheringa, v. 1, p. 401-406.

1146 Williams, G. L., 1978, Dinoflagellates, Acritarchs and Tasmanitids: in Haq, B. U., and Boersma, Anne (eds.), Introduction to Marine Micropaleontology: New York, Elsevier, p. 322-324.

1147 Williams, H. S., 1881, Channel fillings in Upper Devonian Shales: American Journal of Science, 3d series, v. 21, p. 318-320.

1148 , 1882a, New crinoids from the rocks of the Chemung period of New York: Proceedings of the Academy of Natural Science of Philadelphia, p. 17-34.

$1149 \quad, 1882 \mathrm{~b}$, Notes on some fish-remains from the Upper Devonian rocks of New York state: Proceedings of the American Association for the Advancement of Science, 30th Meeting, p. 192193.

$1150 \quad$, 1882c, Catalogue of the fossils of the Chemung period of North America: Ithaca, New York, $14 \mathrm{pp} . *$

$1151 \quad, 1882 \mathrm{~d}$, The recurrence of faunas in the Devonian rocks of New York: Proceedings of the American Association for the Advancement of Science, v, 30, p, 186-191.*

1152 , 1883a, On a remarkable fauna at the base of the Chemung Group in New York: American Journal of Science, 3d series, v. 25, p. 97-104.

$1153 \ldots$ 1883b, Comparative paleontology of the Devonian formation: Science, v. 2, p. 836-837.*

$1154 \ldots$, 1884a, On the fossil faunas of the Upper Devonian ... : U.S. Geological Survey Bulletin 3, 36 pp. 
1155 Williams, H. S., 1884b, The spirifers of the Upper Devonian: Science, v. 3, p. 374-375.

1156 , 1885, Notice of a new Limuloid crustacean from the Devonian: American Journal of Science, $3 d$ series, v. $30, p .45$.

$1157,1886 \mathrm{a}$, Notes on the fossil fishes of the Genesee and Portage black shales: Buffalo Society of Natural Science Bulletin, v. 5, p. $81-84 . *$ , 1886b, On the classification of the Upper Devonian: Proceedings of the American Association for the Advancement of Science, v. 34, p. 222-234.* , 1886c, Devonian Lamellibranchiata and species making: American Journal of Science, 3d series, v. 32, p. 192-198. 1887, On the fossil faunas of the Upper Devonian, the Genesee section, New York: U.S. Geological Survey Bulletin 4l, $104 \mathrm{pp}$. , 1889, On the relation of the Devonian faunas of Iowa: American Geologist, v. 3, p. 230-233.

1162 __ 1899, The Devonian interval in northern Arkansas: American Journal of Science, 4th series, v. 8, p. 139-152. , 1903. The correlation of geological faunas, a contribution to Devonian paleontology: U.S. Geological Survey Bulletin $210,147 \mathrm{pp}$.

1165 , 1910, Migration and shifting of Devonian faunas: Geological Society of America Bulletin, v. 21, p. 285-294. , 1913, Recurrent Tropidoleptus zones of the Upper Devonian of New York: U.S. Geological Survcy Professional Paper 79, $103 \mathrm{pp}$.

1166 Williams, H. S., and Kindle, E. M., 1905, Contributions to Devonian paleontology: U.S. Geological Survey Bulletin 244, p. $67-91$.

1167 Williams, H. U., 1886, Notes on the fossil fishes of the Genesee and Portage black shales: Buffalo Society of Natural Science Bulletin, v. 5, p. 81-84.*

1168 Williams, S. G., 1887, The Tully Limestone, its distribution and its known fossils: New York State Geologist 6th Annual Report, p. 13-29.*

1169 Willis, Bailey, 1909, Pal eogeographic maps of North America: Journal of Geology, v. 17, p. 286-288.

1170 William, H. B., $\Lambda$ thorton, Elwood, Buschback, T. C., Collinson, Charles, Frye, J. C., Hopkins, M. E., Lineback, J. A., and Simon, J. A., 1975, Handbook of Illinois stratigraphy: Illinois State Fenlogic.a 1 Survey Bulletin $95,261 \mathrm{pp}$.

1171 Wilson, J. L., and Majewske, 0. P., 1960, Conjectured middle Paleozoic history of central and west Texas: Texas University Publication 6017, p. 65-86.

1172 Winchell, Alexander, 1887, l'errible fishes and their companions: in Walks and talks in the geological field, New York: Chautauqua Press, p. 183-184.

1173 Winche11, N. H., 1874, The geology of Dclaware County: Ohio Geological Survey, v. 2, part 1, p. 272-313.

1174 Winder, C: G., 1962, Upper Devonian age of the Kettle Point Shale: Transactions of the Royal Society of Canada, 3d series, v. 56, p. 85-95. 
1175 Winder, C. G., 1966, Conodont zones and stratigraphic variability in Upper Devonian rocks, Ontario: Journal of Paleontology, v. 40, p. 1275-1293. , 1967, Micropaleontology of the Devonian in Ontario: in Oswald, D. H. (ed.), International Symposium on the Devonian System, 1967 Proceedings, Calgary, Alberta, Alberta Society of Petroleum Geologists, v. 2, p. 711-719.

1177 Winslow, M. R., 1962, Plant spores and other microfossils from Upper Devonian and Lower Mississippian rocks of Ohio: U.S. Geological Survey Professional Paper 364, 93 pp.

1178 Woodrow, D. L., Fletcher, F. W., and Ahrnsbrak, W. F., 1973, Paleogeography and paleoclimate at the deposition sites of the Devonian Catskill and Old Red facies: Geological Society of America Bulletin, v. 84, p. 3051-3064.

1179 Woodward, A. S., 1900, On a new ostracoderm (Euphanerops longaevus) from the Upper Devonian of Scaumenac Bay, Province of Quebec, Canada: Annals and Magazine of Natural History, Series 7, v. 5, p. 416-419.*

$1180 \ldots$ _ 1906, The relations of palaeontology to biology: Annals and Magazine of Natural History, Series 7, v. 18, p. 315.*

1181 Woodward, H. P., 1943, Devonian System of West Virginia: West Virginia Geological Survey, v. XV, 655 pp.

1182 Wright, A. A., 1893, On the ventral armor of Dinichthys: Ohio Geological Survey, v. 7, p. 620-626.

1183 , 1894, The ventral armor of Dinichthys: American Geologist, v. 14, p. 313-320.

$1184 \ldots$ _ 1897, New evidence upon the structure of Dinichthys (abstr.): Ohio State Academy of Science 5th Annual Report, p. $59-60 . *$

1185 Wyrtki, K., 1961, The thermohaline circulation in relation to the general circulation in the oceans: Deep-Sea Research, v. 8, p. 39-64.

1186 , 1962, The oxygen minimum in relation to ocean circulation: Deep-Sea Research, v. 9, p. 11-23.

1187 Yande11, L. P., and Shumard, B. F., 1847, Contributions to the geology of Kentucky: Louisville, 36 pp.*

1188 Younquist, W. L., 1945, Upper Devonian conodonts from the Independence Shale (?) of Iowa: Journal of Paleontology, v. 19, p. 355-367.

1189 _ 1947, A new Upper Devonian conodont fauna from Iowa: Journal of Paleontology, v. 21, p. 95-112.

1190 Younquist, W. L., and Miller, A. K., 1948, Additional conodonts from the Sweetland Creek Shale of Iowa: Journal of Paleontology, v. 22 , p. 440-450.

1191 Ziegler. Willi, 1962, Taxionomie und Phylogenie Oberdevonishcer Conodonten und ihre stratigraphische Bedeutung: Abhandlungen des Hessicschen Landesamtes fur Bodenforschung, v. 38, $166 \mathrm{pp}$.

$1192 \ldots$ _ 1973a, b, c, Catalogue of Conodonts: 'Stuttgart, E. Schweizerbart'sch Verlagsbuchhandlung, a) v. I, $504 \mathrm{pp}$., b) v. II, $404 \mathrm{pp}$., c) v. III, $574 \mathrm{pp}$. 
1193 Zielinkski, R. E., Dixon, J. A., McIver, R. D., and Reaugh, A. B., 1979, Projection of favorable gas-producing areas from paleoenvironmental data: in Third Eastern Gas Shale Symposium, October 1-3, 1979, Mound Facility, Miamisburg; Ohio, $18 \mathrm{pp}$. 
Acanthodes: 0361,0533

Acritarchs: 0077, 0324, 0325, 0326, 0327, 0707, 0796, 1024, $1043,1136,1137,1138,1139$, 1146

Actinophorus: 0204,0533

Actinopteria: $0248,0675,1166$

Aganides: 0269,0477

Agoniatites: $0864,0870,1166$

algae: 0595, 0639, 0675, 0734, 1112,1138

2lgae, pelagic: 0820,1138

algal flotant theory: 0231, 0664, 1107

Allorhynchus: 0664

Allorisma: $0269,0533,0929$

Alveolites: 0533

Ambocoelia: $0032,0136,0477$, 0512, 0533, 0588, 0865, 0886, 0926, 0927, 0929, 0986, 1106, 1166

Ammodiscus: 0238

Amphissites: 0533, 0673, 0983, 1011,1087

anaerobic basins: 0125, 0371, 0894

anaerobic conditions: 0125, 0788

Anaptychus: :0032, 0533, 1011

Ancyrodella: $0094,0233,0490$

Ancyrognathus: $0094,0233,0490$

Anc.yrnspnra: $\quad 0707$.
Angulodus: 0553

Angustidontus: 0136,0248 , 0271, 0272, 0493

annelid teeth: 0158

Annularia: 0533

Anoplotheca: 0870,1166

anoxic ocean: $0026,0072,0120$, 0304,0920

Araucarioxylon: 0636

Archaeocaris: 0391

Archeopitys: 0136,0878

Archaeopteris: 0050,0052 , 0053, 0138, 0287, 0596, 0640, $0842,0846,0980$

Archoceras: 0540

Arnoldella: 0136

Arthrodires: $0295,0299,0300$, 0359, 0337, 0339, 0340, 0341, 0343, 0344, 0506, 0528, 0560, $0563,0564,0566,0567,1002$

Arthropoda: 0062, 0902, 0903, 0924

Aspidichthys: 0032, 0084, 0206, 0533, 0620, 0772, 0786, 0865

Asterocalamites: 0019

Asterolepis: 0927

Asteroptychius: 0533

Asteroxylon: $0069,0136,0271$, 0272,0533

Athyris: 0446, 0533, 0675, 0865,1085 
atmosphere history: 0677

Atrypa: $0259,0533,0886$

Aulopora: 0533, 0997, 1011

Aulospora: 0707

Avicula: 0533,0675

Aviculopecten: $0533,0675,0870$, 0886

$$
-\mathrm{B}-
$$

Bactrites: 0727,0871

Bairdia: $0533,0982,1011,1087$

Barroisella: 0136, 0233, 0259, 0390, 0391, 0533, 0615, 1014,

barnacles: 0154, 0165, 1132

Bellerophon: 0391, 0404, 0512, 0533, 0669, 0927, 0929

benthic communities: 0079, 0684, 0685

Bertillonella: $\quad 0533,1011,1087$

Beyrichia: 0044

biogenic structures: 0120, 0121, 0122

Bissaculus: 0533,1011

bitumen, origin: 0454, 0778, $0805,0807,0808,0810$

bituminous rocks: 0037, 0105, 0171, 0370, 0471

Black Sea : 0303

black-shale bibliography: 0386, $0581,0614,1064$

black shale, modern: 0415, 1027, 1066

black-shale paleoenvironments: 0099, 0103, 0171, 0230, 0231,
0417, 0451, 0659, 0663, 0664, 0741, 0800, 0917, 0948, 1066, 1069

black-shale radioactivity: 0045, 0100, 0309, 0377, 0379, $0400,0414,1021,1022,1026$, 1027,1028

black shales: 0330, 0557, 0582, 0646, 0841, 0876, 0884, 1051, 1052

bone beds: 0238, 0239, 0240, $0241,0244,0245,1012,1105$, 1106

see phosphatic debris

borings: 0136,0664

Bothriolepis: $\quad 0361,1120$

Botryococcus: 0533

brachiopod biostratigraphy: 0593

brachiopods: 0263, 0458, 0593, $0594,0696,0912,0913,1101$

brachiopods, diminuitive: 0177,0217

brachiopod ecology: 0262, 0267 , 0815, 0816, 0834, 0912, 0913, 1001,1049

brachiopods, lingulid: 0046 , 0267, 0412, 0815, 0816, 0872, $1001,1049,1145$

brevicones: 0389

Brontichthys: $0198,0206,0533$

Bryantodus: $0414,0490,1028$

bryozoans: 0664

Buchiola: 0675, 0871, 0886, see Avicula

Bungartius: 0533 
Burlella: 0533

see Quasillites

Bythocypris: 0533,1010

Bythocyproidea: 0533,1010

$$
-\mathrm{C}-
$$

Calamites: 0018, 0019, 0533, 0638

Calamophyton: 0075

Calamopityeae: 0879

Calamopitys: $0136,0271,0272$, 0878

Calamopteris: $\quad 0136,0878$

Calamospora: 0533

calcareous concretions: 0136 , 0393, 0768

calcispheres: 0144, 0595, 0734, 0989

Calcisphaera: 0595

Callixylon: 0015, 0016, 0017, 0018, 0019, 0020, 0048, 0050, 0051, 0070, 0071, 0136, 0231, 0271, 0272, 0366, 0451, 0493, 0533, 0535, 0536, 0575, 0640, 0664, 0872, 0935, 0969, 1028, 1103,1104

Callognathus: 0206, 0533, 0619, 0620,0786

Camarotoechia: 0084, 0136, 0269, 0477, 0533, 0551, 0581, 0664, $0865,0870,0886,0926,0927$, $0929,1035,1037,1085$

Carocalophyton: 0008

Cardiocaris: 0174

Cardiola: see Cardiopsis

Cardiomorpha: 0533,0675
Cardiopsis: 0615,0616

Cariniferella: $\quad 0533$

Caulopteris: 0286

Cephalopoda: 0032, 0389, 0413, $0461,0540,0541,0542,0543$, 0544, 0547, 0548, 0549, 0623, 0624, 0643, 0717, 0727, 0729, 0730, 0818, 0934, 0981

Ceratiocaridae: 0061

Ceratiocaris: $\quad 0391,0468$

Ceratoikiscum: 0394 :

Ceratopora: 0533

Chagrinichnites: 0383

Chapelia: 0060

Chesapeake Bay black shale: 0415

Chitinozoa: 0228

Chonetes: 0032, 0084, 0113, $0136,0157,0259,0390,0391$, $0477,0490,0511,0512,0533$, 0551, 0552, 0615, 0616, 0664, 0857, 0865, 0870, 0926, 0977, 0986, 0997, 1011, 1035, 1036, $1037,1106,1166$

cirriped crustaceans: 0154, 1132

cladodont sharks: 0203, 0205

Cladodus: $0136,0191,0192$, $0197,0202,0356,0361,0490$, 0498, 0523, 0533, 0552, 0775, 0862,1003

Cladoselache: 0290,0291 , 0298, 0361, 0482, 0525, 0533, 0651

Cladoxylon: $0136,0271,0272$, 0533,0877

Clepsidropsis: ' 0136 


\section{Clinopistha: 1166}

C1ymenia: 0162, 0533, 0771, 0785, 0865,1086

coalified wood: 0100,0233

Coccosteus: $0110,0192,0193$, 0196, 0206, 0347, 0533, 0775, 0865

Coelonella: 0533, 1011, 1087

Coleolus: $0084,0157,0533,1166$

Colpocaris: $0136,0271,0272$, 0391,0878

Composita: 0929

Concavicaris: see Ceratiocaris, Colpocaris

Conchodus: 0086

conodont color change: 0375 , 0481

conodont paleoecology: 0967

conodonts: $0005,0006,0076$, 0092, 0093, 0094, 0095, 0109, $0137,0151,0152,0155,0227$, ก7.2.9, 02.3n, 0233, 0247, 0249, 0252, 0329, 0331, 0332, 0367, 0375, 0402, 0442, 0481, 0485, 0491, 0492, 0497, 0515, 0519, 0532, 0552, 0553, 0554, 0623, 0625, 0626, 0628, 0629, 0630., 0635, 0661, 0688, 0721, 0731, 0741, 0757, Uis8, 0759; 0760, 0761, 0804, 0805, 0852, 0872, $0887,0920,0923,0953,0959$, $0960,0966,0967,0996,0998$, $1016,1039,1055,1074,1076$, $1142,1175,1188,1189,1191$

Conularia: 0136

conulata: 0705

Convolutispora: $\quad 0707$

corals: 0533,0801
Cordaites: 0935

Cornellites: see Pterinea

Corythoecia: 0394

Cranaena: 1035,1037

Crangopsis: 0806

Crania: 0032, 0533, 0986

Craniella: 0870 see Petrocrania

crinoids: $0470,0664,0674$, 0691, 0738, 0968, 1103, 1104, 1141,1148

crustaceans: $0061,0063,0153$, $0154,0163,0166,0173,0184$, 0468, 0806, 0902,.0914, 0964, $1018,1123,1130,1132,1133$, 1156

Cryptostomata: 0533

Ctenacanthus: $0185,0350,0361$, $0523,0533,0666,0772,0775$

Ctenoconularia: $\quad 0705$

Ctenodus: 0533,0865

Ctenoloculina: U535, 1011

Cycloceras: 0269,1088

Cyclora: 0042,0136

Cymatiosphaera: $\quad 0707,1139$

Gyperites: 0282

Cypricardella: 0259, 0392, 0533, 0669

see Microdon

Cypricardinia: $0084,0675,1035$

Cypridina: 0533

Cypridinella: 0136 
Cyrtentactinia: $\quad 0394$

Cyrtia: $0145,0533,0865$

Cyrtina: 0533

Cyrtospirifer: 0308,0533

see Cryptospirifer

Cytherella: 0533

see Cytherellina

Cytherellina: $\quad 1087$

$$
-\mathrm{D}-
$$

Dadoxy1on: $0018,0533,0666$, 0669, 0831, 0865

Dalmane11a: $\quad 0533,0865,0870$

deep-water origin: 0892

delta, Upper Devonian: 0034, 0035,0675

Delthyris: 0533, 0551, 0552, 0664

depth indicators: 0103, 0471, 0789

dermal plates: 0043

Devonian biostratigraphy: 0047, 0101, 0331, 0332, 0489, 0527, $0529,0540,0542,0547,0548$, 0593, 0623, 0630, 0688, 0707, $0758,1039,1087,1109,1191$

Devonian coal: 0233, 0833

Devonian correlations: 0246 , 0259, 0321, 0547, 0549, 0678, $0690,1100,1163$

Devonian-Mississippian boundary: 0112, 0218, 0225, 0233, 0237, 0240, 0244, 0272, 0377, 0443, 0477, 0493, 0533, 0537, 0608, 0610, 0627, 0637, 0707, 0722, $0723,0725,1034,1038$

Diad emodus : $\quad 0483$
Dictyonema: 0114,0918

Dielasma: 0415

Dielasmella: 0136

Diexallophasis: $\quad 0707$

Diichnia: $0136,0878,0879$

Dinichthyids: 0083, 0346, $0347,0348,0353,0559,0977$

Dinichthys: $0081,0082,0084$, $0086,0136,0189,0195,0199$, 0206, 0208, 0209, 0231, 0233, 0289, 0292, 0293, 0302, 0356, 0392, 0505, 0533, 0558, 0629, 0669, 0742, 0772, 0774, 0775, 0780, 0786, 0897, 0977, 0992, $1005,1182,1183,1184$

Dinognathus: 0533

Dinomylostoma: 0361

Dinophyceae: 0796

Diplodode11a: 0553

Diplodus: 0355,0361

Diplognathus: $0206,0342,0533$

Dipterocaris: 0155

Dipterus: 0086,0356

Discina: see Orbiculoidea

Discinocarina: 0174,0914

Douvillina: 0446,0886

Duishergia: 0233

Dunkleosteus: 0507,1004 see Dinichthys

dwarf faunas: $0643,0645,0672$, 0934, 0964, 0976

dysaerobic basins: 012.3, 0364, 0788,0889 
Echinocaris: $0533,1018,1130$

Echinoderms: 0169, 0470, 0674, 0738

Edmondia: $\quad 0533,0675$

Emanue11a: 0136

Endosporites: $\quad 0080,0320$

Endothyra: 1053

Entartina: 0395

Entactinosphaera: 0395

Entomis: 0044

Entomozoe: 1087 see Entomis

Eodevonaria: 0310

Eodon: 0206,0675

Eoorodus: 0086

epiplankton: $0691,0800,0865$, $0912,0968,1103,1104,1141$

Erie1la: $\quad 1087$

estuaries, ancient: 0631

Eumetria: 0929

Euomphalidae: see Euomphalus

Euompha1us: 0084,0533

Euphanerops: 0361

Euprioniodina: 0515

eurypterids: $0182,0433,0463$, 0464

euxinic basins: 0123

Exochoderma: 1139
Exochops: 0415

$$
-F-
$$

Favosites: 0533

Fenestella: 0533

fish fossils: 0085,0086 , $0155,0183,0187,0192,0196$, 0214, 0215, 0216, 0294, 0301, 0338, 0352, 0354, 0356, 0360, $0361,0362,0363,0447,0522$, 0525, 0561, 0562, 0565, 0568, ก.57n, 0571, 0572, 0574, 0.553, $0654,0732,0742,076 \%, 0768$, 0769, 0772, 0776, 0777, 0779, 0783, 0786, 0798, 0872, 0906, 0932, 0933, 0978, 1062, 1063, $1080,1109,1121,1122,1123$, $1124,1125,1126,1128,1149$, $1157,1167,1172,1179$

Foerstia: $0106,0231,0490$, 0533, 0650, 0734, 0762, 0763, 0792, 0793, 0794, 0847, 0872, 0939, 0940, 0958, 1021, 1027, 1118

see Protosalvinia

fondo origin: 0893

Foraminifera: $0234,0235,0236$, 0237, 0242, 0279, 0728, 1012, 1053,1061

Forbesiocrinus: 0533,1148

forests, Devonian: 0053, 0054, 0181, 0420, 0421, 0459, 0460, 0886

fossil bone petrography: 0901

fossil wood: $0011,0015,0056$, 0100, 0181, 0186, 0288, 0366, 0421, 0533, 0675, 0886, 0930, 1113,1191

fossils, oriented: 0597

Franklinella: 0533,1011 
Frasnian-Famennian mass extinction: 0264

fructifications: 0711,0962

$$
-G-
$$

gastropods: 0461,0670

gastropods, pyritized: 0664

germanium, in fossil wood: 0100

Glottidia: $0815,1001,1049$

Glyptaspis: 0533,0620

Gnathodus: 0607

Gonatodus: 0533

Goniatites: $0084,0161,0391$, $0512,0533,0616,0857,1014$

Goniodus: 0206,0786

Gorgonichthys: 0192, 0196, 0206, 0533

Gorgonisphaeridium: 0707, 1139

Grammysia: $\quad 0145,0533,0675$

graptolites: $0114,0441,0918$

grasshoppers: 0286

gray/green shale environments: 0638

Guycampbella: $\quad 0533$

Gymnotrachelus: 0533

Gypidula: $\quad 0927$

Gyracanthus: 0185,0361

$$
-\mathrm{H}-
$$

Hamburgia: $\quad 0136,0415$

Haplentactinia: 0395
Haploprimitia: 0533

Hedere11a: $\quad 0032,0533$

Helodus: 0086,0772

Hemipronites: 0316

Heteracanthus: 0361

Heterophrențis: 0533

Hibbardella: 0515,0553

Hierogamma : 0136

Hindeode11a: $0233,0515,0758$, 1028

Holdenius: 0533

Holeciscus: 0395

Homacanthus: 0361

Homostius: 0507,1004

Hoplonchus: $0361,0533,0865$

humic matter: 0322

hydrogen sulfide: 1050

Hymenozonotriletes: 0320,0707

Hyolithes: 1166

Hypothyridina: 0136,0253 , 0259, 0851, 0926, 0927, 0929

Hypothyris: see Hypothyridina

hystrichospheres: 0314,0326

$$
\text { - I - }
$$

Icriodus: 0094, 0758, 1091

$\frac{\text { Icriodus }}{1090}$ to Polygnathus ratios:

Imitoceras: 0477,0818 see Aganides 


$$
-\mathrm{J}-
$$

$$
\text { - K - }
$$

Kal ymma: $0136,0878,0965$

Kentuckia: 0525

kerogen: 0097,0098

Kinderhookian: 0250, 0251, 0635, $1016,1055,1073$

Kirkbyella: 1087

Kloedenella: 1011

Kloedenia: $\quad 0044$

$$
-\mathrm{L}-
$$

leaves and leaf-rafts: 0068

Leda: $0084 ; 0393,0512,0533$, 0675

Leiopteria: $0675,0857,0977$

Leiorhynchus: $0113,0136,0145$, $0259,0310,0322,0405,0490$, 0533, 0588, 0501, 0615, 0616, $0617,0664,0857,0864,0865$, 0870, 0921, 0926, 0927, 0977, $0986,1106,1166$

Leiosphaeridia: $\quad 1081,1139$

Lepidodendron: 0136, 0159, 0206, 0271, 0272, 0533, 0669

Lepidostrobus: $0010,0136,0271$, 0.72, 0573, 0711, 0ถ78, ถ७6?, 0980

Leptocoelia: $\quad 0310$

Leprodesma: $0533,0675,1166$

Ligonodina: $0515,0553,0758$

1 imuloid crustacean: 1156
Lingula: $0043,0084,0113$, $0136,0142,0145,0231,0233$, 0259, 0269, 0271, 0272, 0368, 0391, 0392, 0413, 0446, 0490, $0511,0512,0517,0518,0533$, 0551, 0588, 0615,.0638, 0664, 0666, 0667, 0671, 0696, 0743, 0753, 0755, 0786, 0802, 0814, $0861,0865,0916,0927,0986$, $1021,1026,1035,1036,1041$, $1085,1106,1144,1162,1166$

Lingula paleoecology: 0267 , 1049,1145

Lingulichnites: 1041

Lingulipora: $0136,0259,0368$, 0392, 0405, 1021

Lingulodiscina: 0043,0412 , 0533

Lituotuba: 0728

Lonchodina: $0515,0553,1028$

Lopholasma: $0032,0259,0533$ $\frac{\text { Loxonema: }}{0870} \quad 0084,0512,0533$,

Lucasella: 0533

Lunulicardium: $0157, .0533$, 0615, 0675, 0871

Lycopods : 1114

Lycopogenia: 0136

Lyginorachis: $0059,0271,0272$

$$
\text { - M - }
$$

Macrocheilus: $0533,0620,11.11$

Macrochilina: 0616

Macrodon: $0084,0512,0533$, 0675,0756

Macropetalichthys: 0206,0261 , 
$0349,0361,0797,1002,1005$

Maharanites: $\quad 0707$

mangrove swamps: 0640

Manticoceras: $0032,0136,0533$, $0540,0727,1106$

marcasite: 1042,1077

marcasite faunas: 0386

marine, shallow: 0113, 0177, 0499,1020

marine primary production: $1043,1136,1137,1138,1139$

marine shèlf environment: 0028, $0029,0101,0419,0957,1020$

Martinia: $0926,0927,0929$

Mazodus: 0533

megaspores: 0147

Megistocrinus: 0533

Melocrinites: see Melocrinus

Melocrinus: $0032,0157,0470$, $0533,1011,1106,1148$

Meristella: $0136,0405,1085$

Mesoneuron: 0136

Mesothyra: 1018

Michelinia: 0533

Miche1inoceras: see Orthoceras

Micrhystridium: 0707,1139

Microdon: 0393, 0512, 0675

microplankton: $\quad 0323$

Microzygia: $0136,0271,0272$

Mimagoniatites: 0801 mioflora: 0073

miospores: 0276,0689

Mississippian biostratigraphy: $0221,0225, .0229$

Modie11a: 0533

Modiomorpha: $0136,0259,0675$, 0870,1106

Monocladodus: $\quad 0191,0533$

Mourlonia: 0415

Multiplicisphaeridium: $\quad 0707$

Mylos toma: 0086, 0206, 0296, $0361,0528,0533$

Mytilarca: 0675,0886

$$
-\mathrm{N}-
$$

Nalivkine11a: 0801

Naples fauna: 0158, 0167, 0176

Nehdentomis: 0533

Nematophyton: $0826,0829,0830$

Neoprioniodus: 0553

Nucleospira: $0136,0533,0870$

Nucula: $0032,0084,0533,0675$, 0870,1166

Nuculana: $0391,0533,0675$ see Leda

Nuculites: 0533, 0651, 0675, 0870,1166

Nuculoidea: 0675

see Nucula

- 0 -

ocean circulation: 0072, 0099, 0304, 0675, 0892, 0894, 0919, 1185,1186 
Ohiocaris: 0902

Onchus: 0361

Onychodus: 0533,0865

Orbiculoidea: 0043, 0136, 0142, 0231, 0233, 0238, 0269, 0271, 0272, 0391, 0392, 0411, 0490, 0512, 0533, 0551, 0615, 0651, 0664, 0755, 0756, 0786, 0802, 0807, 0861, 0862, 0865, 0870, 0872, 0927, 1021, 1035, 1036, 1106,1166

organic matter maturation: 0038, 0039, 0098, 0099, 0675, 1025

organism oxygon rolationships: 0372, 0889

organism-sediment relationships: 0372

Orodus: $0523,0533,0772,0865$

Orthis: 0393, 0533, 0859

Orthoceras: $0032,0084,0136$, 0164, 0168, 0391, 0408, 0512, 0533, 0616, 0669, 0857, 0871, 0977

Orthothetes: $0533,0551,0552$, 1166

ostracods: $0044,0065,0266$, 0318, 0332, 0424, 0425, 0598, 0606, 0621, 0982, 0983, 1008, $1009,1010,1011,1087,1088$

ostracod paleoecology: 0332, 0606

oxygen deficiency: 0072, 0451 , 0889, 0894, 0919, 1050

Ozarkodina: 0553

$$
\text { - P - }
$$

Pachydome1la: see Senescella
Pachysphaera: 0148,0820

Palaentina: 0533

Palaeoneilo: 0084, 0136, 0446, 0512, 0533, 0616, 0620,0638, 0675,0870

Palaeopalaeomon: 0944,1018 , 1130,1133

Palaeoscenidium: 0395

Palaeosolen: 0084

Paleobotany: 0010, 0012, 0013 , 0014, 0021, 0022, 0023, 0024, 0058, 0069, 0149, 0264, 0271, 0272, 0276, 0278, 0280, 0281, 028\%, 0305, 0381, 0388, 0450, 0537, 0539, 0656, 0710, 0827, 0828, 0878, 0881, 0882, 0969, $0970,1084,1089,1115,1117$

Paleoclimatology: 0011, 0031, 0036, 0180, 0328, 0457, 0677, 0698, 0704, 0706, 0726, 0842, $0949,0950,0954,1117,1178$

paleocurrents: $0597,0605,0942$

paleoecology: 0257

paleogeography: 0099, 0264, $0306,0471,0473,0196,0501$, 0545, 0546, 0556, 0569, 0578, 0591, 0594, 0597, 0695, 0698, 0699, 0700, 0726, 0746, 0943, 0946, 0947, 0952, 0974, 0979, $1097,1116,1144 ., 1169,1178$

paleomagnetic reconstructions: $0328,0457,0726,0746$

Palconiscus: 0155, 0523, 0553, 0772,0862

Paleosabella: 0134

Palmatodella: 0233,0490

Palmatolepis: $0094,0151,0233$, $0368,0415,0664,0758,1028$ 
palynomorphs: 0697,0883

Panderodella: 0553,1028

Panenka: 1166

Paracardium: 0259

Parallelodon: 0136, 0477, 0533, 0865, 0929

see Macrodon, Palaentina

Paramylostoma: 0533

Paraparchites: 0533 see Coelonella

Parodiceras: 0870,1166

pelagic larvae: 1058

pelecypods: $0125,0462,0465$, $0664,0675,0676,0800,0988$

pelecypod paleoecology: 0988

perched faunas: 0592

Periastron: 0055, 0136, 0271, 0272,0878

Petrocrania: 0533

Phacops: 0136,0533

Phaebodus: 0361, 0533

Pharetrella: 0871

phosphate nodules: 0136,0233 , 0451, 0508, 0664, 1021

phosphates, marine: 0103, 0693, 0694, 0848, 0974

phosphatic lng deporits: 0451

Phthonia: 0533

Phyllocarida: 0063, 0163, 0173, 0902

Phytokneme: 0010
Pietzschia: $0136,0271,0272$

Pinacodus: 0094

placoderms: $0190,0194,0198$, 0200, 0206, 0210, 0220, 0302, 0781,0843

plankton, Paleozoic: 0915, 0916, $0990,1043,1081,1136,1137$, $1138,1139,1140$

plankton, Recent: 1081

plants, marine: 0938

plants, terrestrial: 0008, 0012, 0014, 0022, 0023, 0060, $0069,0070,0073,0271,0272$, $0280,0286,0444,0538,0640$, $0712,0879,0963$

P1atyceras: $0136 ; 0533,0551$, 0552

Platycrinites: see platycrinus

Platycrinus: $0470,0533,1148$

Platyrachella: 0136, 0551, 0552, 0664

Platystrophia: 0702

Plethospira: $0136,0392,0404$, 0616

Pleuropterygian sharks: 0233

Pleurotomaria: $0084,0392,0512$, 0533, 0616, 1166

P1icoplasia: $\quad 0310$

P1icorachis: 0136

Plumulites : 0154

Polydryxium: 0707

Polyentactinia: 0395

Polygnathellus: 0553 
Polygnathids: $0554 ; 0844$

Polygnathus: 0151, 0415, 0607, $0758,0992,1028,1091,1176$

Polygnathus varcus Group: 0629

Polylophodonta: 0094, 0233, $0490,0664,1028$

Polyrhizodus: 0533,0865

Polyxylon: 0271,0272

Ponderodictya: 0533

Pontocypris: 0533

Poteriocrinites: see Poteriocrinus

Poteriocrinus: 0533,1148

Praecardium: 0136 see Panenka, Paracardium

Prasinophycean algae: 0074, 0148,0820

Prestwichia: 1156

Prioniodina: 0553

Prioniodus: 0392, 0405, 0415, $0490,0515,0607,1028$

Probeloceras: 0624,0871

Producte11a: 0415, 0533, 0865, $0886,0997,1011,1085$

Productus: $0511,0533,0859$

Proetides: 0477

Proetus: 0533,0801

progymnosperms: 0056,0057 , 0138,0931

Promacrus: 0533

Prothyris: 0533

Protocalamites: $\quad 0136,0271,0272$
Protokionoceras: 1085

Protosalvinia: 0106,0148 , 0231, 0233, 0287, 0445, 0762, 0792, 0793, 0794, 0840, 0847, 0958,0984

Prototaxites: 0025, 0037, 0231, $0233,0650,0791,0936$

Psephodus: 0086

Psuedaviculopecten: 0675 see Aviculopecten

psuedoplankton, crinoids: 0691, 0968

see ejiplanktor

Psuedopolygnathus: 0094

Pterichthys: 1120

pteridosperms : 0596

Pterinea: $0533,0675,0886$

Pterinopecten: $\quad$ “0512, 0533, 0675,0857

Fterochaenia: 0446,0871

Pteropods : 0461

Ptychopteria: 0259

Ptychtodas: $0094,0.361$

pyrite: 0067;0672, 0675, 0708, $1021,1042,1077$

pyrite fauna: $0386,0672,0708$

$$
-Q-
$$

Quasillites: 0533, 1087

see Burlella, Lucasella

Quisquiletes: 0707

$$
\text { - R - }
$$

radiolarians: $0001,0233,0394$, 0395, 0451, 0508, 0521, 0531, 
0708, 0898, 1061

Reimania: $\quad 0136,0272$

Reimanniopsis: 0272

Reptaria: $0032,0533,1011$

Reticularia: $0145,0533,0865$

Rhacophyton: 0009, 0265

Rhadinichthys: 0084, 0136, 0231, 0233, 0533, 0992

\section{Rhinocaris: 0163}

rhipidistian fishes: 1057

Rhipidome11a: 0136, 0259, 0393, 0533, 0551, 0552, 0664, 0870, $0929,1035,1036,1037$

rhizocarps: 0283,0284

Rhombina: 0533

Rhynchodus: 0361

Rhynchonella: $\quad 0259,0533,0786$

rhynchone11ids: 0696

Rhynchopora: 0664,0929

Richterina: 0533, 1011, 1087

Roemerella: 0733

Romingeria: 0415,0533

Ropolene1lus: $0533,1011,1087$

$$
-S-
$$

Sanguinolites: see Sphenotus

Sansabe11a: $0533,1011,1087$

sapropel: 0919,1027

scad fly: 0286

Schizobolus: 0043, 0113, 0136,
$0.259,0310,0391,0490,0588$

$0591,0597,0615,0616,0927$,

$0929,1036,1037,1166$

Schizodus: $0533,0651,0675$

Schizophoria: $0533,0651,0886$

Schucherte11a: 0136, 0259, 0393, 0533, 0664, 0865, 0886, 1035

scolecodonts: . 0520,0664

Scolithus: 0157

sealevel changes: 0313

seed ferns: 0329

Semitextularia : $\quad 0728$

Senescella: $0533,1011,1087$

Senziella: 0707

serpulid worms: 0133

shale oil: 0027,0692

shallow water model: see marine, shallow

sharks, fossil: 0191, 0201 , 0.203, 0205, 0298, 0299, 0483, 0526, 0567, 0655, 0906

Siderel1a: $0136,0271,0272$, 0881

Siphonodella: $0320,0415,0664$

Siphonognathus: 0094

skatcs: 0351

Soleniscus: 1111

see Macrocheilus, Macrochilina

Solenocaris: 0136,0878

Solenognathus: 0094

Spathiocaris: $0084,0136,0153$, 
0155, 0174, 0233, 0368, 0493, 0533, 0616, 0664, 0878, 0914, $0916,1037,1102$

Spathodus: 0136

Spathognathodus: 0233,0320

Sphenotus: 0259, 0533, 0675, 0929

Spinocyrtia: see Platyrachella

Spirifer: $0084,0145,0259,0533$, 0865, 0870, 0886, 0926, 1085

Spiriferina: 0533

Spirophyton: 0136

sponge spicules: 0110, 0445, 1176

Sporangites: $0032,0043,0113$, 0136, 0285, 0405, 0588, 0607, $0692,0724,0805,1011,1014$

spores: $0147,0156,0276,0282$, 0529, 0613, 0687,.0688, 0689, 0690, 0707, 0833, 0853, 0896, $0938,0811,1065,1110,1177$

Sporocarpon: 0613

sporocarps: 0285, 08iu

spumellarian radiolarians: 0233 , 0394, 0395

stagnation, oceanic: 0233 , 0919

Staurodruppa: 0395

Steloxylon: $0136,0271,0272$

Stenognathus: 0504

Stenokuleos: 0049,0272

Stenomelon: 0136, 0271, 0272, 0878

Stenosteus: 0084,0992
Stereopteris: 0136,0878

Stethacanthus: 0533

Straparollus: 0032, 0533, 0616

stratified waters: 0304

Streblotrypa: 0533

Streptelasma: 0032,0533

Strophalosia: 0533, 0612, 0615, 0617, 0927, 0997, 1011, 1166

Stropheodonta: 0086, 0136, $0533, \cdot 0870,0997$

Strophodonta: see Stropheodonta

Strophomena: 0512,0533

Styliola: $0157,0392,0615$, 0616, 0786, 0857, 0927

Styliolina: 0113, 0136, 0253, 0310, 0321 \&. 0404, 0451, 0490, 0533, 0591, 0597, 0617, 0651, $0664,0870,0977,1011,1166$

Stylonurus: 0062

Synprioniodina: $\quad 055.3$

Syringopora: 0533

Syringospira: 0259

Syringothyris: 0136,0145 , 0259, 0533, 0865, 0929, 1035, 1037

\section{$-\mathrm{T}=$}

Taghanic onlap: 0591

Tamiobatis: 0351

Taonurus: $0451,0607,0664$, 0878

Tasmanites: 0074, 0106, 0148, 0231, 0233, 0271, 0272, 0326, 
0368, 0451, 0493, 0664, 0708, 0721, 0734, 0790, 0805, 0853, 0872, 0985, 1021, 1028, 1081, 1146,1176

see Sporangites

Taxocrinus: 1148

Tegeolepis: 0345

Tentaculites: 0032, 0136, 0310, 0490, 0533, 0597, 0615, 0616, $0664,0753,0997,1011,1166$

Tetradella: $\quad 0533$

tetrapods, Devonian: 0579, 0706, 1108

Tetrentactinia: 0395

thermohaline circulation: 1185

Thrallella: $0533,1011,1087$

Timanites: $\quad 0730$

Tioga bentonite: 0244, 0315, 0316, 0317

Titanichthys: 0188, 0192, 0194 , $0207,0336,0347,0503,0525$, 0533, 0566, 0782, 0784, 0865

Tolypammina: 0238

Tornacea: 1139

Tornoceras: $0032,0259,0477$, 0533, 0727, 0997, 1011, 1085, 1086,1106

see Parodiceras

trace fossils: $0113,0120,0121$, 0122, 0383, 0384, 0387, 0396, $0416,0451,04 \% 5,0664,0675$, $0706,0872,1001,1021,1041$

Trachosteus: 0300,0533

trade winds: 0328

Trepospira: 0651 see Plourotomaria, Tripospira
Trichonode11a: 0553

Trigonoglossa: 0413

trilobites: 0.468

Tripospira: 0533

Tripododiscus: 0533

Tropidocaris: 0136

Tropidoleptus: 0618, 0675, $0870,0875,1030,1165,1166$

tuff-reworking model: 0309

Tylothyris: 0136,0664

$$
\text { - U - }
$$

Ulrichia: $\quad 1087$

Ungerella: 1087 see Franklinella

Uniellum: 0707

upwelling currents: 0104, 0304, $0500,0661,0675,0693,0734$

uranium: 0107

uranium, in fossil wood: 0100

uranium-1ead dating: 0219

$$
=\mathrm{V}-
$$

vertebrate paleontology: 0104 , 0150, 0220, 0561, 0580, 0706, 0787, 0843, 0907

vertebrates, air-breathing: 0036, 0579, 0706, 1108

Veryhachium: 0707,1139

Vitulina: 0253,0258

$$
-W-
$$

Werneroceras: 0136,0727 
worm borings: 0134

worm trails: 0136

$-\mathrm{X}-$

Xenodus: 0865

$-\mathrm{Y}-$

$-\mathrm{Z}-$

Zaphrentis: 0533

Zeacrinites: see Zeacrinus

Zeacrinus: 0533 